\title{
ALTERAÇÕES E SOLOS DESENVOLVIDOS A PARTIR DE ROCHAS VULCÂNICAS ÁCIDA DA FORMAÇÃO SERRA GERAL NA REGIÃO DE PIRAJÚ (SP)
}

\section{SILVIA ALESSANDRA TRUFFI}

\author{
Geóloga
}

Orientador: Prof. Dr. CELSO AUGUSTO CLEMENTE

Dissertação apresentada à Escola Superior de Agricultura "Luiz de Queiroz", Universidade de São Paulo, para obtenção do título de Mestre em Agronomia, Área de Concentração: Solos e Nutrição de Plantas.

PIRACICABA

Estado de São Paulo - Brasil

Dezembro - 2000 


\section{Dados Internacionais de Catalogaçāo na Publicaçāo (CIP) DIVISĀO DE BIBLIOTECA E DOCUMENTAÇÃO - Campus "Luiz de Oueiroz"/USP}

Truffi, Silvia Alessandra

Alteraçōes e solos desenvolvidos de rocha vulcânica ácida da formação serra geral na regiẵo de Pirajü (SP) / Silvia Alessandra Truffi. - - Piracicaba, 2000.

116 p. : il.

Dissertação (mestrado) -- Escola Superior de Agricultura Luiz de Queiroz, 2000.

Bibliografia.

1. Latossolo vermelho-escuro 2. Petrologia 3. Piroxênio 4. Plagioclásico 5. Rocha vulcânica I. Titulo

CDD 552.2

Tesmitida a cóna total ou parcial deste documento dexde que citada a fonte - O autor 


\section{ÍNDICE}

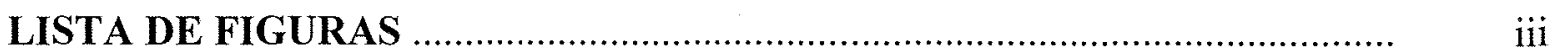

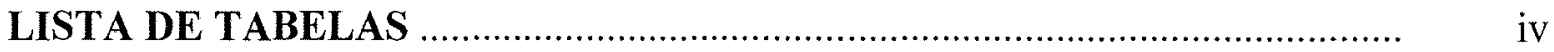

LISTA DE FOTOMICROGRAFIAS .............................................................. iv

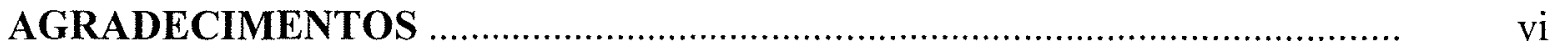

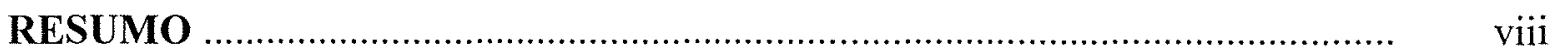

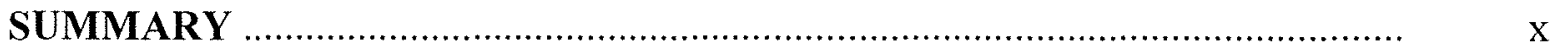

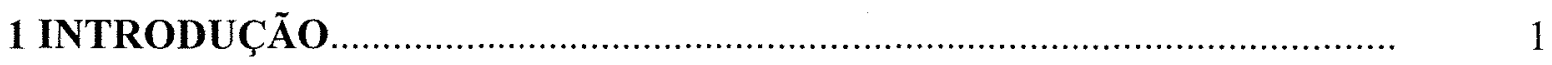

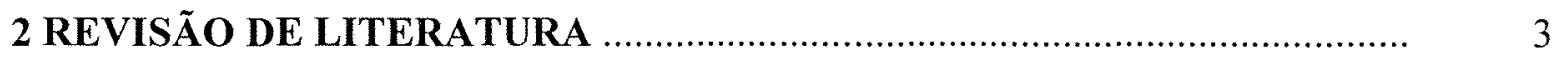

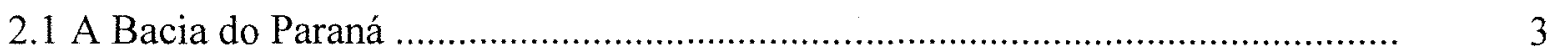

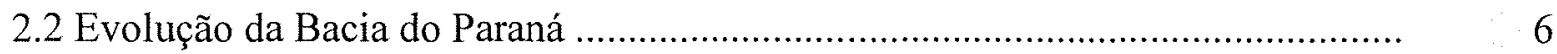

2.3 Aspectos petrológicos do vulcanismo da Bacia do Paraná ................................. 7

2.4 Intemperismo e tipos de solos desenvolvidos sobre as rochas vulcânicas da

Bacia do Paraná ...................................................................................................

3 MATERIAL E MÉTODOS ..........................................................................

3.1 Localização, clima, geologia .......................................................................... 14

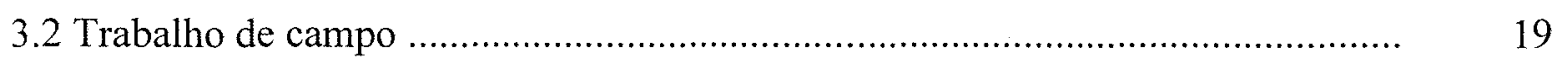

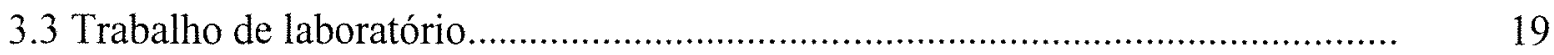

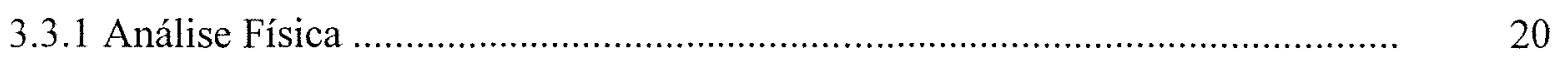

3.3. 2 Análise Química .................................................................................... 20

3.3. 2.1 Fluorescência de raios $-X$........................................................................ 20

3.3.2.2 Análise química ................................................................................... 20

3.3.2.3 Ferro livre (amorfo e cristalino) ............................................................... 21

3.3.2.4 Ataque sulfúrico e determinação dos índices de intemperismo $\mathrm{Ki}$ e $\mathrm{Kr}$........ 21

3.3.3 Análises Mineralógicas................................................................................... 21 


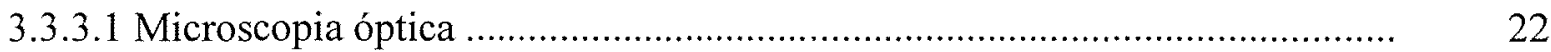

3.3.3.2 Análises por difração de raios - X ............................................................. 24

3.3.3.3 Microscopia eletrônica de varredura (MEV) ………...................................... 25

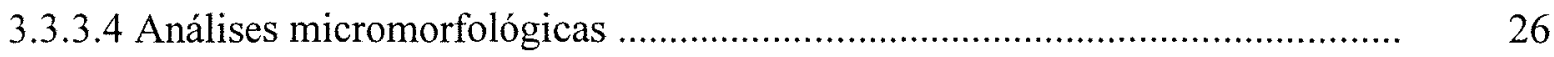

4 RESULTADOS E DISCUSSÃO …………………........................................ 27

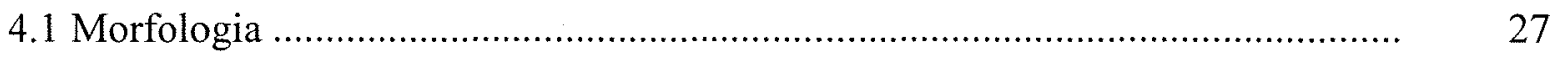

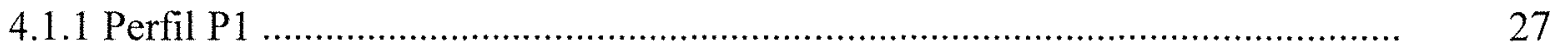

4.1.2 Perfil P2 ................................................................................... 30

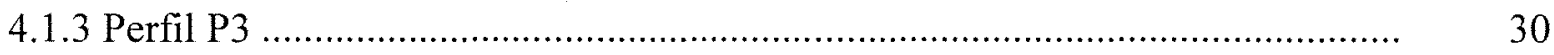

4.1.4 Perfil P4 ............................................................................................... 31

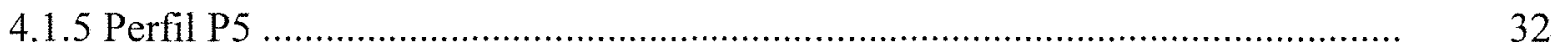

4.2 Evidências Físicas .................................................................................. 38

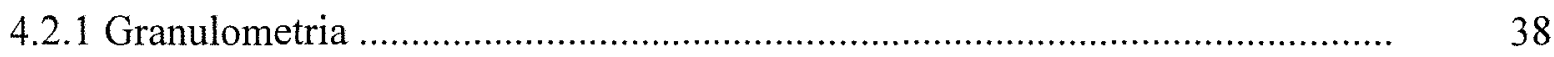

4.3 Evidências Químicas ............................................................................ 38

4.3.1 Análise química e análise por ataque sulfúrico ................................................ 38

4.3.2 Análise por fluorescência de raios - X .........................................................

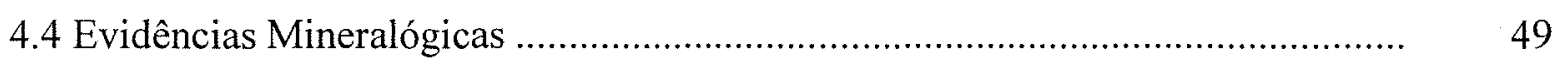

4.4.1 Análises por microscopia óptica ………………............................................. 49

4.4.2 Análises mineralógicas ................................................................................. 51

4.4.3 Análises por microscopia eletrônica de varredura ............................................ 69

4.4.3.1 Alteração dos minerais do grupo do plagioclásio ........................................... 69

4.4.3.2 Alteração dos minerais do grupo do piroxênio ............................................... 86

4.4.3.3 Alteração da matriz do riodacito ................................................................. 94

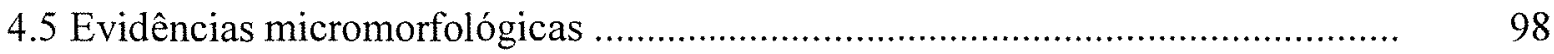

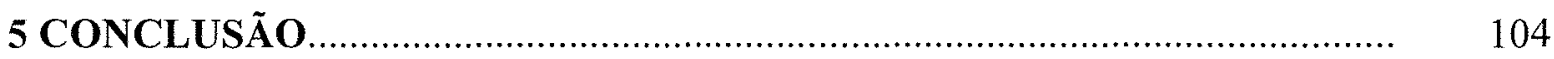

REFERÊNCIAS BIBLIOGRÁFICAS …....................................................... 107

Anexo A - Descrição macromorfológica dos perfis estudados ............................ 115 


\section{LISTA DE FIGURAS}

Figura 1 - Localização da Bacia do Paraná. $\quad 04$

Figura 2 - Lineamentos Geológicos da Bacia do Paraná. 05

Figura 3 - Localização da área estudada no Estado de São Paulo. $\quad 14$

Figura 4 - Extrato da precipitação média mensal da região de Pirajú - SP. $\quad 15$

Figura 5 - Extrato de balanço hídrico da região de Pirajú - SP. 16

$\begin{array}{ll}\text { Figura 6 - Mapa geológico simplificado da região estudada. } & 18\end{array}$

Figura 7 - Representação esquemática da topossequência estudada. $\quad 28$

Figura 8 - Fotografia dos perfis mostrando seus diferentes horizontes e camadas. $\quad 34$

Figura 9-Detalhe das fases de alteração do Perfil P1. 36

Figura 10 - Detalhe das fases de alteração do Perfil P4. 37

Figura 11 - Difratograma de raios - X da fração argila orientada do Perfil P1. $\quad 52$

Figura 12 - Difratograma de raios - X da fração argila orientada do Perfil P2. $\quad 54$

Figura 13 - Difratograma de raios - X da fração argila orientada do Perfil P3. $\quad 56$

Figura 14 - Difratograma de raios - X da fração argila orientada do Perfil P4. $\quad 58$

Figura 15 - Difratograma de raios - X da fração argila orientada do Perfil P5. $\quad 60$

Figura 16 - Difratograma de raios - X da fração silte do Perfil P1. 64

Figura 17 - Difratograma de raios - X da fração silte do Perfil P2. 65

Figura 18 - Difratograma de raios - X da fração silte do Perfil P3. 66

Figura 19 - Difratograma de raios - X da fração silte do Perfil P4. $\quad 67$

Figura 20 - Difratograma de raios - X da fração silte do Perfil P5. 68

Figura 21 - Difratograma de raios - X da fração areia do Perfil P1. $\quad 70$

Figura 22 - Difratograma de raios - X da fração areia do Perfil P2. 71

Figura 23 - Difratograma de raios - X da fração areia do Perfil P3. 72

Figura 24 - Difratograma de raios - X da fração areia do Perfil P4. 73

Figura 25 - Difratograma de raios - X da fração areia do Perfil P5. 74

Figura 26 - Análise química qualitativa da fotomicrografia $5 . \quad 82$

Figura 27 - Análise química qualitativa da fotomicrografia $6 . \quad 88$

Figura 28 - Análise química qualitativa da fotomicrografia $7 . \quad 90$

Figura 29 - Análise química global de toda área da matriz do riodacito. 97

Figura 30 - Esquema de disposição dos horizontes e localização de coleta das 101 amostras indeformadas. 


\section{LISTA DE TABELAS}

Tabela 1 - Propriedades físicas dos solos e das alterações da topossequência 39 Timburi.

Tabela 2 - Análise química dos solos e das alterações da topossequência 42 Timburi.

Tabela 3 - Análise por ataque sulfúrico dos solos e das alterações da 45 topossequência Timburi.

Tabela 4 - Análise por fluorescência de raios - X da topossequência Timburi.

\section{LISTA DE FOTOMICROGRAFIAS}

Fotomicrografia 1 - Microscópio óptico e microscópio eletrônico de varredura mostrando vesicula preenchida por zeólita.

Fotomicrografia 2 - Início da alteração do plagioclásio em finas fraturas de 78 alguns micrometros de espessura.

Fotomicrografia 3 - Alteração do plagioclásio ocorrendo na superfície de 79 clivagem do cristal, com os espaços deixados preenchidos totalmente por caolinitas. 
Fotomicrografia 4 - Plagioclásio transformado totalmente em gibbsita. $\quad 80$

$\begin{array}{ll}\text { Fotomicrografia } 5 \text { - Várias formas de alteração do plagioclásio. } & 81\end{array}$

Fotomicrografia 6 - Goethitas de hábito mamelonar que se encontram nas 87 cavidades de dissolução dos plagioclásios.

Fotomicrografia 7 - Caolinitas formando matriz de aspecto granular e de formato hexagonal.

Fotomicrografia 8 - Sistemas de fraturas finas e sinuosas do piroxênio 92 preenchidas por hidróxidos de ferro.

Fotomicrografia 9 - Estrutura em "Boxwork" do piroxênio alterado com 93 preenchimento por hematita.

Fotomicrografia 10 - Detalhe da matriz do riodacito correspondente aos perfis 96 P1, P2, P3, P4 e P5.

Fotomicrografia 11 - Haloisitas de hábito acicular presentes na matriz do 99 riodacito.

Fotomicrografia 12 - Goethitas com vários hábitos presentes na matriz do 100 riodacito. 


\section{AGRADECIMENTOS}

- Ao professor Dr. Celso Augusto Clemente, pela orientação, ensinamentos e amizade;

- Ao Departamento de solos e Nutrição de Plantas, pela oportunidade de realização do mestrado;

- A CAPES, pela bolsa de estudos concedida;

- À professora Dra. Célia Regina Montes-Lauar, pela acolhida no Núcleo de Pesquisa em Geoquímica e Geofísica de Litosfera (NUPEGEL/ESALQ/USP);

- Ao professor Dr. Ronaldo Ivan Silveira pelo apoio e amizade;

- Ao professor Antonio José Ranalli Nardy (UNESP), pelas análises concedidas de fluorescência de raios-X;

- Ao amigo Álvaro Luiz Mafra, que nos acompanhou na viagem ao campo e pela ajuda na descrição morfológica dos perfis.

- Aos funcionários do laboratório de física do solo: Elizabete, Wlademir, Luciano e Flávia;

- Ao Engenheiro Ney Sampaio, pelo auxílio nas análises de difração de raios-X e microscopia eletrônica de varredura;

- Aos pós-graduandos: Silvia, Neide e Ricardo e em conjunto aos funcionários do Departamento de Solos e Nutrição de Plantas, pelo convívio. 


\section{Ofereço}

Ao meu pai Antonio Odival Truffi e a minha mãe Teresinha Maria Vendemiatti Truffi, como forma de agradecimento por tudo aquilo que vocês fizeram e representam para mim.

Dedico

Aos meus irmãos Marcelo e André e ao Luiz

pelo companheirismo e carinho incondicionais 


\title{
ALTERAÇÕES E SOLOS DESENVOLVIDOS A PARTIR DE ROCHAS VULCÂNICAS ÁCIDAS DA FORMAÇÃO SERRA GERAL NA REGIÃO DE PIRAJÚ (SP)
}

\author{
Autora: SILVIA ALESSANDRA TRUFFI \\ Orientador: Prof. CELSO AUGUSTO CLEMENTE
}

\section{RESUMO}

Este trabalho apresenta os resultados de estudos petrológicos, químicos, mineralógicos e micromorfológicos nas rochas vulcânicas ácidas (riodacitos da Formação Serra Geral), nas alterações e nos solos desenvolvidos sobre estas rochas, dando ênfase para a evolução mineralógica dos plagioclásios, piroxênios e da matriz.

Foram realizadas análises químicas e mineralógicas em amostras de alteração e no solo de uma topossequência, totalizando 5 perfis desenvolvidos sobre riodacitos.

Determinações químicas qualitativas e semi-quantitativas obtidas por microscopia eletrônica de varredura (MEV) em fragmentos de rocha alterada, aliada, aos resultados obtidos a partir das análises mineralógicas normais e das análises de micromorfologia permitiram importantes interpretações e conclusões, a saber:

1) os fenocristais, tanto o plagioclásio quanto o piroxênio do riodacito apresentam uma sequência de evolução bastante simples.

2) os cristais de plagioclásio se alteram principalmente em caolinita e mais raramente em gibbsita, mica e haloisita. 
3) a principal característica de alteração do piroxênio é a formação de estruturas porosas ("Boxwork") com preenchimento de hematitas e secundariamente goethitas ao longo de seu sistema de clivagem e fratura.

4) a evolução da matriz do riodacito é: matriz $\Rightarrow$ caolinita + óxidos e hidróxidos de Fe.

5) a análise micromorfológica identificou dois tipos de plasma: a) de coloração marrom - avermelhado sem orientação, isto é, de estrutura asépica de domínios identificáveis, não orientados entre si (argila sépica); b) outro como um plasma de coloração alaranjado, rico em separações plásmicas (estrutura masépica), isto é, estriações paralelas ao alongamento das zonas, em uma ou várias direções, ou envolvendo grãos do esqueleto e vazios, em estrutura do tipo vo-esquel-masépica. 


\title{
ALTERATIONS AND DEVELOPED SOILS FROM THE VOLCANICS ACIDS ROCKS FROM "SERRA GERAL" FORMATION IN PIRAJÚ (SP) AREA
}

\author{
Author: SILVIA ALESSANDRA TRUFFI \\ Adviser: Prof. CELSO AUGUSTO CLEMENTE
}

\section{SUMMARY}

The research exposes the results of studies made in petrologics, mineralogical and micromorphological volcanics acids rocks (rhyodacites of from Serra Geral Formation), in the modification and soil developed above this rocks, making clear the mineralogical evolution of plagioclases, pyroxenes, inclusively in the matrix.

Analyses were made in the samples alteration, chemical and mineralogical, in a cathenas soil, obtaining five developed profiles on ryodacites.

Chemical qualitative and semi-quantitative determination in scanning eletronic microscopy (SEM) in fragments of changed rocks, connected to the results showed in the mineralogical and micromorphological analyse, allowed significant interpretation and closing:

1 - the phenocrysts, even plagioclase and pyroxene of the ryodacite presents a sufficently simple sequence of evolution.

2 - the plagioclase crystal change mainly in kaolinite, and rarely in gibbsite, mica and haloysite.

3 - the main change characteristic of pyroxene is the porous structure formation ("Boxwork") with the fulfilling of hematites and goethites through the cleavege and fracture system.

4 - the rhyodacite matrix evolution is: kaolinite + oxide and hidroxide Fe. 
5 - the micromorphologic analyse recognises two different kinds of plasma: a) a red-brown coloration without orientation, of asepic structure of recognizable domain; no guided itself (sepic clay). b)another one as a plasma with orange coloration, with a plasmic dissociation abundant (masepic structure) parallel striation in the zone extension, in one or several directions, involving grains of the empty skeleton, in vo-esquel-masepic structure. 


\section{INTRODUÇÃO}

Os derrames vulcânicos, na sua maior parte, são constituídos por rochas basálticas (ocupando mais de $60 \%$ da superfície terrestre), podendo ocorrer tanto nos oceanos, principalmente ao longo de cadeias meso-oceânicas, como sobre os continentes, na forma de derrames de platô, como os platô do Deccan (Índia), Karroo (África) e o da Bacia do Paraná (Brasil).

Do ponto de vista petrográfico, os derrames de lavas distribuídos em toda extensão da Bacia do Paraná, foram descritos como sendo basaltos de composição homogênea (Leinz,1949; Almeida, 1981; Ruegg, 1976).

Mais recentemente (Bellieni et al., 1986; Sartori, 1984; Nardy,1987; Comin-Chiaramont et al., 1983; Piccirillo et al., 1987 entre outros) mostraram que são dois os principais tipos de rochas: 1) expresso pelos basaltos e andesi-basaltos e 2) riólitos e dacitos, cuja maior diferenciação reside no aspecto químico.

Os diferentes tipos de basalto se distinguem por apresentarem altas e baixas concentrações de titânio $\left(\mathrm{TiO}_{2}\right)$ e elementos incompatíveis ( $\mathrm{Sr}, \mathrm{Ba}, \mathrm{Zr}$ e Nb).

Segundo Iyomasa (1994) as rochas vulcânicas ácidas, constituem estratos (derrames) separados por contatos difusos, diferentemente dos que ocorrem nos basaltos, onde via de regra verificam-se brechas e juntas discordantes. Possuem matriz vítrea, parcial ou totalmente devitrificada (em quartzo e feldspato alcalino, com abundância de microcristais de minerais opacos e filossilicatos associados em quantidades menores). Nesta matriz dispõem-se microfenocristais e fenocristais de plagioclásio e piroxênio, por vezes isorientados. No topo dos derrames, os Latitos exibem grande quantidade de amígdalas e vesículas (Latito Vesicular). Logo abaixo, adquirem aspecto compacto, com textura porfirítica e estrutura fluidal difusa (Latito Compacto Fluidal). Na parte central 
do derrame os latitos apresentam-se compactos e homogêneos (Latito Compacto Homogêneo). Com base em análises petrográficas essas rochas foram classificadas como latitos a quartzo-latito, ou como riólitos (se considerado o quartzo das amígdalas, fraturas e paredes de vesículas). De modo geral, apresentam $50-60 \%$ de plagioclásio, $30-40 \%$ de feldspato alcalino, com quantidades de quartzo entre $5 \%$ (latitos) e $20-$ $25 \%$ (riólitos).

A composição mineralógica das rochas da Bacia do Paraná é simplesmente formada na sua maior parte por plagioclásio, minerais ferromagnesianos, opacos (magnetita e ilmenita), quartzo e vidros.

Sobre essas rochas, as ações intempéricas e pedológicas fizeram por desenvolver os solos mais bem aproveitados do Brasil, cujos materiais merecem estudos por parte de vários pesquisadores.

Os processos de alteração intempérica de rochas que ocorrem na natureza são extremamente lentos.

A determinação desses processos que levam a transformação de uma rocha em solo é de grande importância, tanto cientificamente como no sentido de abrir novos campos de pesquisa mineral e de um melhor uso do solo.

Trabalhos referindo-se à alteração superficial, na Bacia do Paraná, são poucos e destacam-se entre outros: Delvigne, 1965; Melfi \& Levi 1971; Levi \& Melfi 1972; Menegotto \& Gasparetto, 1987; Gonçalves, 1987; Hypólito,1972; Clemente 1988; Gasparetto, 1990.

\section{1 - OBJETIVOS}

A determinação de uma sequência evolutiva durante a intemperização dessas rochas vulcânicas ácidas, nas condições climáticas e topográficas locais, constitui-se num dos objetivos do trabalho.

Em seguida, propõe-se estudar a evolução dos minerais primários presentes entre eles os plagioclásios, os piroxênios e também a matriz da rocha.

Por fim, pretende-se traçar uma comparação com a evolução desses mesmos minerais mas em condições climáticas completamente distintas. 


\section{REVISÃO DE LITERATURA}

\subsection{A BACIA DO PARANÁ}

A Bacia do Paraná está situada no centro-leste da América do Sul, abrange uma área de $1.600 .000 \mathrm{~km}^{2}$, distribuídos pelos territórios do Brasil (1.000.000 $\left.\mathrm{km}^{2}\right)$, na Argentina $\left(400.000 \mathrm{~km}^{2}\right)$, no Uruguai e Paraguai $\left(100.000 \mathrm{~km}^{2}\right.$ de extensão cada).

Em território brasileiro a Bacia do Paraná abrange grandes áreas nos Estados de Mato Grosso, Mato Grosso do Sul, São Paulo, Paraná, Santa Catarina, Rio Grande do Sul, e parte dos Estados de Minas Gerais e Goiás, atingindo quase $2.000 \mathrm{~km}$ de extensão (Petri \& Fúlfaro, 1983) (Figura 1).

As feições estruturais de maior importância são os arqueamentos (arcos), alinhamentos tectônicos e áreas de maior subsidência (Figura 2).

Os arcos de Ponta Grossa e Sul- Rio Grandense possuem direção NW e são bem visíveis nos mapas geológicos pela curvatura do embasamento Pré-Cambriano que avança em direção à Bacia. O arco de Ponta Grossa é responsável pela divisão da Bacia nas sub-bacias do Alto Paraná (São Paulo, Minas Gerais e Goiás) e Paranaense Catarinense (Paraná e Santa Catarina) (Figura 2).

Entre os arcos de Ponta Grossa e Sul - Rio Grandense ocorre a estrutura de Torres, linha tectônica de direção oeste-nordeste / leste-sudeste, entre Torres e Pousada (Leinz, 1949), que é responsável pela separação das sub-bacias Catarinense e Uruguaia - Sul - Rio Grandense (Rio Grande do Sul e Uruguai), (Petri \& Fúlfaro, 1983) (Figura 2). 


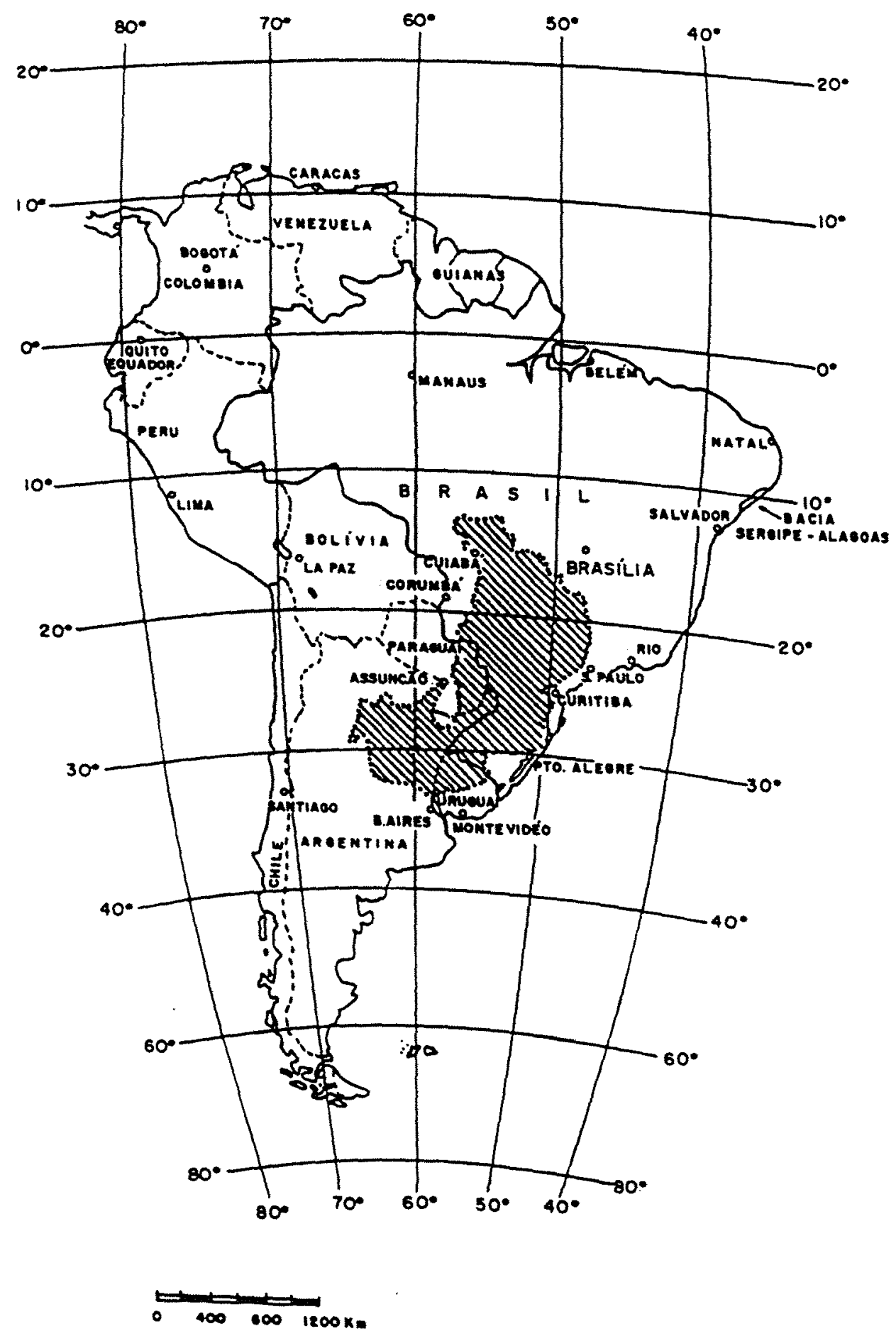

Figura 1 - Localização da Bacia do Paraná. (Segundo Northfleet et al, 1969). 


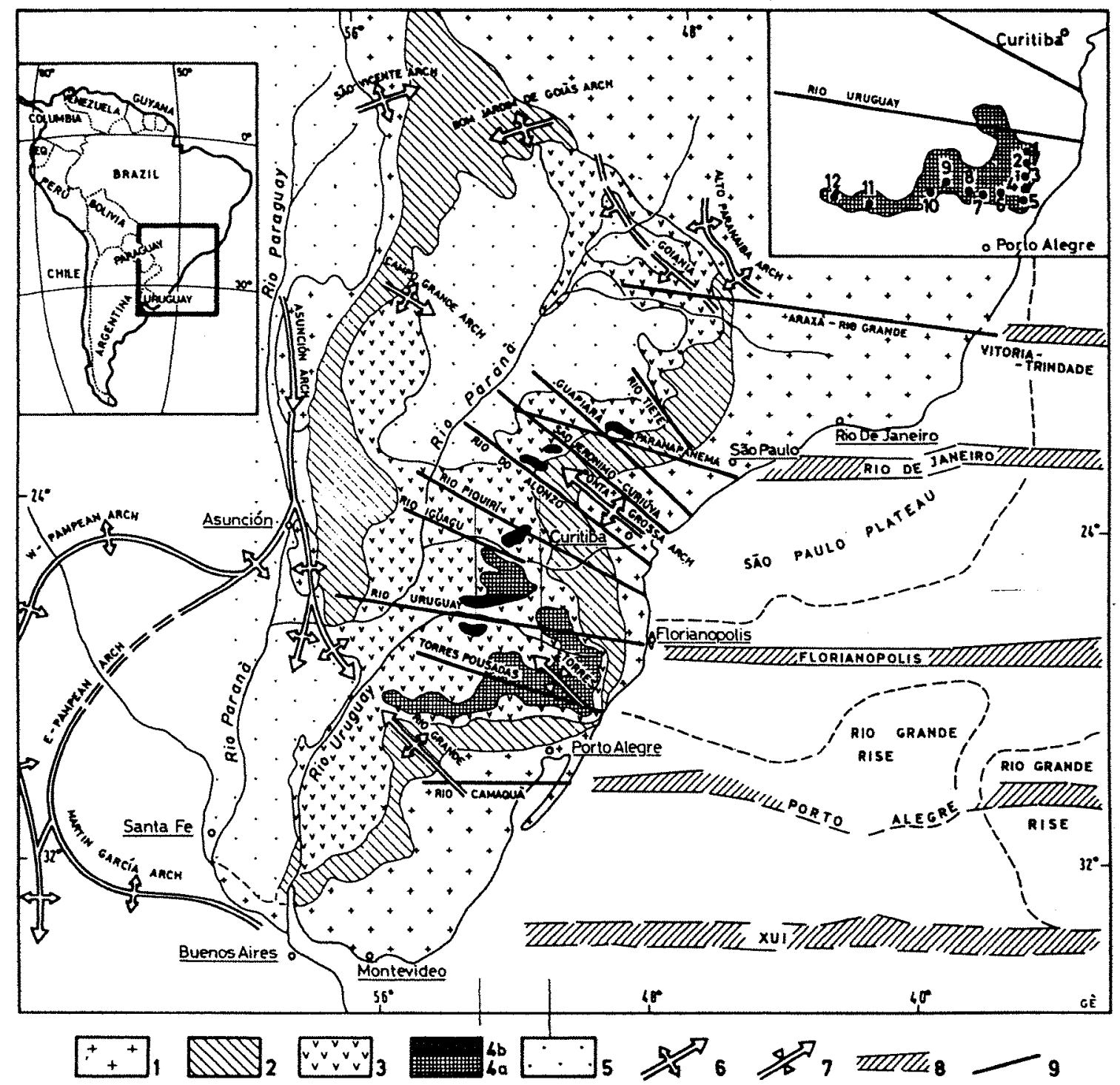

Figura 2 - Lineamentos geológicos da bacia do Paraná (Fonte: Bellieni, et al. 1986).

Mapa geológico simplificado da Bacia do Paraná, da região do embasamento cristalino adjacente e região oceânica. Legendas:1 - Sedimentos pré-vulcânicos (predominantemente do Paleozóico). 2 - derrames básico-intermediários (Formação Serra Geral). 3 - Derrames ácidos (Formação Serra Geral): Tipo Palmas (ATP), Tipo Chapecó (ATC). 4 - Sedimentos pós-vulcânicos (Cretáceo Superior). 5 - Sedimentos Quaternários. 6 - Estruturas em arco. 7 - Estruturas em sinclinal. 8 - Alinhamentos tectônicos e/ou magmáticos. 
$\mathrm{O}$ arco de Assunção, com cerca de $800 \mathrm{~km}$ de extensão e de orientação geral norte-sul, é a estrutura positiva mais importante marginal à Bacia, pois, é responsável pela separação da Bacia do Paraná da Bacia Chaco - Paraná (Almeida, 1981).

Preenchida por espessos pacotes de rochas sedimentares e vulcânicas, com idades variando do Siluriano ao Cretáceo e atingindo espessuras máximas da ordem de $6.000 \mathrm{~m}$, a Bacia do Paraná teve sua configuração fortemente condicionada a arqueamentos e flexuras do embasamento cristalino, profundamente afetado por episódios tectonomagmáticos do ciclo Brasiliano (Almeida, 1981; Petri \& Fúlfaro, 1983).

\subsection{EVOLUÇÃO DA BACIA DO PARANÁ}

O início da história evolutiva da Bacia do Paraná data do Devoniano Inferior, quando ocorreu a reativação das linhas de fraqueza do Embasamento da Plataforma Sul-americana e deposição de sedimentos marinhos do Grupo Paraná. No Carbonífero Inferior/Permiano Superior, movimentos tectônicos soerguem as bordas e deprimem o centro da bacia ativando os processos erosivos e deposicionais marinhos e continentais com resquícios da glaciação permo-carbonífera (Grupo Tubarão).

No final do Paleozóico e início do Jurássico predominavam na área condições de clima desértico propiciando a deposição de sedimentos arenosos continentais de origem eólica pertencentes a Formação Botucatu.

Importantes eventos tectônicos com efusão de lavas basálticas e intrusivas vulcânicas da Formação Serra Geral ocorrem no final do Jurássico e início do Cretáceo sendo que, após seu término, intenso falhamento e erosionamento dissecou a bacia. Posteriormente ocorreu a deposição de sedimentos do Grupo Bauru (Almeida, 1981 e Fúlfaro et al., 1982). 


\subsection{ASPECTOS PETROLÓGICOS DO VULCANISMO DA BACIA DO PARANÁ}

O vulcanismo do tipo fissural que ocorreu em toda extensão da Bacia do Paraná, no Mesozóico, deu-se de maneira intermitente, na forma de sucessivos derrames de lavas de grande espessura, totalizando uma área de $1.200 .000 \mathrm{~km}^{2}$.

Datações radiométricas realizadas por Melfi (1967), Piccirilo et al. (1987), Bellieni et al. (1986) entre outros, revelaram que o vulcanismo Serra Geral ocorreu há 140-120 milhões de anos atrás.

Pequenas lentes e camadas de arenito podem intercalar-se a esses derrames que, ora apresentam vesículas e amigdalas preenchidas por material secundário, como calcita, quartzo, zeólita, etc., ora apresentam-se compactos e o conjunto todo é conhecido como Formação Serra Geral (Petri \& Fúlfaro, 1983).

A Formação Serra Geral assenta-se em discordância sobre as rochas sedimentares da Formação Botucatu, ou mais antigas, ou mesmo diretamente sobre o embasamento Pré-Cambriano, como na borda nordeste da Bacia (Minas Gerais e Goiás), Petri \& Fúlfaro (1983).

Um grande número de intrusões menores, ocorrem associadas ao vulcanismo, principalmente na forma de sills e diques, que cortam as diferentes litologias nas regiões onde afloram os derrames (Minioli et al., 1971).

Os sills são encontrados em áreas sedimentares, possuindo espessuras variáveis de pouco metros até 200 metros.

A maior área ocupada por sills, que se tem notícia, é aquela que abrange grande parte dos municípios de Limeira, Piracicaba e municípios vizinhos, no estado de São Paulo, atingindo uma área de $900 \mathrm{~km}^{2}$ (Petri \& Fúlfaro, 1983).

As mesmas observações são relativamente válida para os diques, cujos estudos feitos por Comim-Chiaramont et al. (1983), revelam variações na composição toleítica-transicional, com elevados teores de $\mathrm{TiO}_{2}$.

As maiores concentrações de diques aparecem na região do arco de Ponta Grossa, abrangendo partes dos estados do Paraná e São Paulo. 
A frequência de diques pode atingir localmente várias dezenas por quilômetros, como na Serra do Cadeado (Paraná), Capão Bonito e Fartura (São Paulo) (Fúlfaro \& Suguio, 1967).

De um modo geral, as pesquisas mais recentes sobre as rochas vulcânicas da Bacia do Paraná (Bellieni et al, 1986; Nardy et al., 1993) demonstraram que essa Bacia pode ser dividida em três (3) porções principais:

1) a primeira região ou região Norte é aquela que se localiza acima do lineamento do rio Piquiri onde predominam litotipos básicos e pequenas ocorrências de rochas ácidas do tipo "Chapecó". Estas rochas fazem parte do grupo que apresentam alta concentração de titânio e elementos incompatíveis. (Figura 2).

2) a segunda região se localiza abaixo do lineamento do Uruguai onde predominam também os litotipos básicos porém com grande expressão de rochas ácidas do tipo "Palmas", concentradas especialmente nas porções mais elevadas dos Planaltos meridionais do Rio Grande do Sul e Santa Catarina e fazem parte do grupo de rochas com baixa concentração de titânio e elementos incompatíveis. (Figura 2).

3) a terceira corresponde a região Central, entre os lineamentos dos rios Piquiri e Uruguai, que apresenta rochas básicas assim como rochas ácidas do tipo "Palmas" e "Chapecó". (Figura 2).

A distribuição das rochas não é aleatória uma vez que estas rochas se encontram preferencialmente para a borda leste da bacia.

Sartori et al. (1982) mostraram que na porção centro-oeste de Santa Catarina e no Estado do Paraná as rochas ácidas estão presentes em altitudes superiores a 1000 metros enquanto que no Estado de São Paulo estas rochas afloram em altitudes mais modestas, nas proximidades do rio Paranapanema, próximo às barragens de Xavantes e Armando Laydner, respectivamente nos municípios de Xavantes e Pirajú.

As rochas vulcânicas básicas são basaltos e andesi-basaltos geralmente de granulação fina, textura ofítica ou subofítica e a coloração é cinza-escuro a cinza-médioescuro. 
Apresentam fenocristais de plagioclásio, clinopiroxênio (augita), opacos (magnetita e ilmenita) e olivina, sendo que esta aparece quase sempre alterada e microfenocristais de plagioclásio, clinopiroxênio, pigeonita e opacos. A matriz é composta pelos mesmos minerais acima citados mas também pode conter feldspato alcalino, quartzo, apatita e quantidades variadas de material vítreo (Raposo, 1987; Nardy, 1987; Sartori et al., 1982; Nardy et al ., 1993).

As rochas ácidas (riólitos e dacitos) do tipo Palmas são caracterizadas por apresentar feno ou microfenocristais de plagioclásio, piroxênio, magnetita e ilmenita, envolvidos por uma trama constituída essencialmente por quartzo e feldspato microcristalino (Nardy, 1987).

As rochas vulcânicas ácidas do tipo Chapecó são caracterizadas por apresentarem textura fortemente porfirítica com presença de macro e mesofenocristais de plagioclásio, piroxênio, magnetita e ilmenita, imersos em uma matriz semi-vítrea a microcristalina (Nardy, 1987).

\subsection{INTEMPERISMO E TIPOS DE SOLOS DESENVOLVIDOS SOBRE AS ROCHAS VULCÂNICAS ÁCIDAS E BÁSICAS DA BACIA DO PARANÁ.}

No Brasil, os trabalhos envolvendo alteração de rochas são escassos. Se considerarmos e separarmos os trabalhos por tipos de rochas tais como, vulcânicas e intrusivas, ácidas e básicas estes tornam-se menos frequentes ainda.

A alteração intempérica das rochas vulcânicas é bastante rápida em nossas condições climáticas uma vez que essas rochas são constituídas de minerais altamente intemperizáveis. Logo nos primeiros estágios de alteração já há a transformação de quase toda sua mineralogia inicial.

Os estudos sobre as alterações das rochas básicas são comuns, como trabalhos de Melfi (1967); Melfi \& Levi (1971); Gonçalves (1987); Menegotto (1986), entre outros. Entretanto as alterações das rochas vulcânicas ácidas foram pouco estudadas, pois não se tinha o conhecimento de sua presença. Apenas alguns trabalhos 
realizados no Sul do Brasil, entre eles o de Menegotto \& Gasparetto (1987), fazem menção da alteração e dos tipos de solos desenvolvidos sobre estas rochas.

Estes autores concluíram que a alteração tanto nas rochas básicas como nas ácidas, se dá de forma concêntrica, típica decomposição esferoidal, isto quando condicionada a uma estrutura maciça com poucas diáclases. Quando a rocha apresenta intenso diaclasamento ou estrutura vesicular a alteração é do tipo vertical.

A intemperização determina a destruição sucessiva dos minerais na seguinte ordem crescente de estabilidade: piroxênio $<$ plagioclásio $<$ feldspato alcalino < magnetita $<$ quartzo.

Os principais produtos de alteração das rochas básicas são a esmectita, os géis amorfos e subordinadamente a goethita.

Entre as rochas vulcânicas ácidas, a alteração do vitrófiro origina a esmectita em elevada proporção, enquanto que o riólito forma géis amorfos, caolinita, ilita e menores proporções de esmectita.

Clemente (1988) realizou um trabalho sobre os produtos de alteração e solos desenvolvidos sobre as rochas vulcânicas ácidas na região de Guarapuava e Palmas, dando ênfase a evolução mineralógica dos plagioclásios, piroxênios e material vítreo. De acordo com o autor, a alteração dos minerais das rochas ácidas coincide com a alteração das rochas vulcânicas básicas, numa sucessão de fases, em ordem decrescente, tem-se: olivina $>$ plagioclásio $>$ piroxênio $>$ magnetita $>$ feldspato alcalino $>$ quartzo.

Quanto aos resultados obtidos por aquele autor podemos destacar que em relação dos plagioclásios, estes seguem três linhas evolutivas principais, ou seja:

plagioclásio $\rightarrow$ gibbsita

plagioclásio $\Rightarrow$ geles $\Rightarrow$ gibbsita

plagioclásio $\Rightarrow$ geles $\Leftrightarrow$ gibbsita + caolinita

Em relação aos piroxênios, estes apresentam também 3 linhas evolutivas principais:

piroxênio $\Rightarrow$ goethita

piroxênio $\rightarrow$ esmectita e goethita 
piroxênio $\rightarrow$ goethita + preenchimento de suas estruturas porosas ("Boxworks") por Al formando a gibbsita.

Por último, a magnetita, onde os principais produtos de sua alteração equivalem a hematita e a goethita.

Nesta região, o processo intempérico principal que ocorre é a bissialitização. Entretanto, a formação de caolinita sugere também o processo de monossialitização parcial.

O autor considera que em termos de velocidade de lixiviação as condições estão próximas ao limite entre os dois processos.

Rosolen (1996) descreve que os primeiros estágios de alteração, tanto básico quanto ácido, caracterizam um material onde a estrutura é conservada, a isoalterita, e ocorrem preferencialmente nos contatos de acamamento e fraturamento da rocha que exibe tonalidade amarelada. Com o avanço do intemperismo, a rocha sã diminui sensivelmente de volume sendo que a textura e estrutura ainda são preservadas.

Neste estágio ainda aparecem sinais marcantes de alteração do plagioclásio, mudança de coloração dos piroxênios e magnetita, que exibem auréolas de alteração com tonalidades avermelhadas.

Num terceiro estágio, pouco se observa da rocha original, que dá lugar a uma matriz argilo-ferruginosa com cores avermelhadas. O piroxênio e a magnetita encontram-se em avançado grau de alteração, liberando o ferro que migra para quase toda a matriz.

Na fase alterita, há mistura do solo de cor avermelhada devido a matriz argilo-ferruginosa com raros núcleos pequenos de rocha sã com bordas alteradas (córtex).

Na última fase de alteração, o solo apresenta textura sempre argilosa, devido ao alto grau de alteração dos plagioclásios, variando do vermelho ao amarelo combinada ou não com a tonalidade bruno acinzentada.

Autores como Delvigne (1965), Novikoff (1974), Boulange (1984) e Lelong (1969) citado por Clemente (1988), mostraram que as alterações de minerais do 
tipo plagioclásio evoluem de acordo com a situação geográfica do material de origem (características climáticas, balanço hídrico, relevo etc).

Em condições tropicais úmidas, regiões de alta pluviosidade e boa drenagem, o plagioclásio apresenta um tipo extremo de transformação e esta transformação é diretamente para gibbsita.

Os piroxênios mostram uma alteração mais acentuada quanto mais intensa forem as condições de temperatura e umidade.

Eswaran (1979) citado por Clemente (1988), conclui que em condições de drenagem imperfeita, os piroxênios se alteram em esmectitas e materiais amorfos e sob condições ferralíticas, os principais produtos de alteração são oxi-hidróxidos de ferro amorfo ou cristalino (goethita).

Segundo Melfi (1967), geralmente o início da alteração ocorre nas linhas de clivagens caracterizado por pequena perda de ferro. A magnetita tem na hematita e na goethita os principais produtos resultantes da alteração, cujo material apresenta cores que variam do vermelho ao violeta (hematita) e do amarelo ao bruno (goethita).

Quanto a matriz dos riodacitos, quando alteradas revelam predominância de alumínio e sílica em relação ao ferro e outros elementos de menor importância. Além disso, existem concentrações ou zonas onde o $\mathrm{Si}$ é um dos únicos elementos presentes, ocorrendo nos espaços deixados por cristais de plagioclásio ou piroxênio.

Quanto aos solos originados sobre as rochas básicas ocorrem solos vermelhos profundos e de boa fertilidade natural sendo classificados como Latossolo Roxo e Terra Roxa Estruturada. O novo sistema brasileiro de classificação de solos (EMBRAPA, 1999), o Latossolo Roxo entra na classe dos LATOSSOLOS VERMELHOS e a Terra Roxa Estruturada entra na classe dos ARGISSOLOS e/ou NITOSSOLOS. Tais solos são responsáveis por altas produtividades agrícolas.

Por outro lado, sobre as rochas ácidas desenvolvem-se solos extremamente argilosos, profundos e com alto teor de alumínio em profundidade. 
De maneira geral, são solos de cores bastante avermelhadas. A produtividade agrícolas em áreas onde dominam as rochas ácidas é menor do que as regiões onde ocorrem as rochas básicas.

$\mathrm{Na}$ região estudada (Pirajú - SP) ocorrem solos da classe Latossolo Vermelho - Escuro. De maneira geral essa classe de solo apresenta horizonte B latossólico vermelho-escuro, de matiz 4YR ou mais vermelho, valores 3 a 5 e croma 4 a 6 e teores de $\mathrm{Fe}_{2} \mathrm{O}_{3}$ inferiores a $18 \%$ quando argilosos ou muito argilosos e usualmente inferiores a $8 \%$ quando de textura média, com atração magnética fraca ou inexistente (Oliveira, 1992).

De acordo com Embrapa (1999) os Latossolo Vermelho - Escuro, correspondem no novo sistema de classificação como LATOSSOLO VERMELHO. 


\section{MATERIAL E MÉTODOS}

\subsection{Localização, clima, geologia}

A área em estudo situa-se na região de Pirajú (SP) e apresenta como latitudes as coordenadas $23^{\circ} 00^{\prime}$ a $23^{\circ} 15^{\prime}$ a sul e como longitude as coordenadas $49^{\circ} 15^{\prime}$ a $49^{\circ} 30^{\prime}$ a oeste (Figura 3 ).

A região localiza-se a sudoeste do Estado de São Paulo, às margens do rio Paranapanema, a $331 \mathrm{Km}$ da Capital. O acesso é facilitado pelas Rodovias SP270 (Raposo Tavares) e pela SP280 (Castelo Branco).

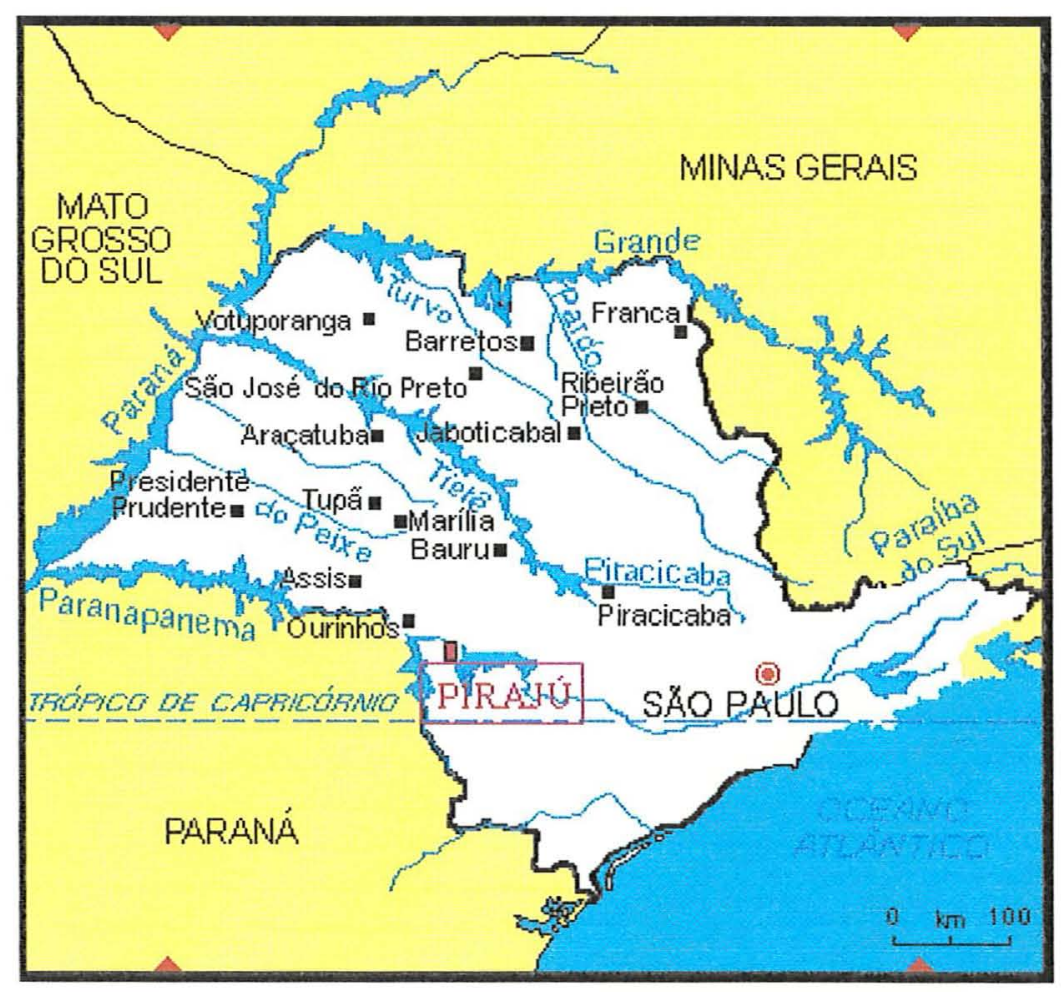

Figura 3 - Localização da área estudada no Estado de São Paulo. 


\section{Clima}

Os dados referentes aos elementos climáticos térmicos (temperatura) e hídrico (precipitação, umidade, evaporação), permitem identificar, segundo o sistema internacional de Köppen, o clima da região de Pirajú como sendo CWA, definido como: Clima quente, bem demarcado sazonalmente por uma estação de verão quente e chuvosa (temperatura maior que $22^{0} \mathrm{C}$ ) e uma estação de inverno seca e amena (temperaturas mínimas ao redor de $18^{\circ} \mathrm{C}$ e precipitação menor que $30 \mathrm{~mm}$ no mês mais seco). (Figura 4).

O índice pluviométrico da maior parte da região mostra uma precipitação de 1100 a $1300 \mathrm{~mm}$ anuais (Figura 5). Este tipo de clima, leva a uma transformação da matéria orgânica, a uma alteração dos constituintes primários das rochas, podendo levar ao desenvolvimento de solos formados tipicamente por minerais secundários.

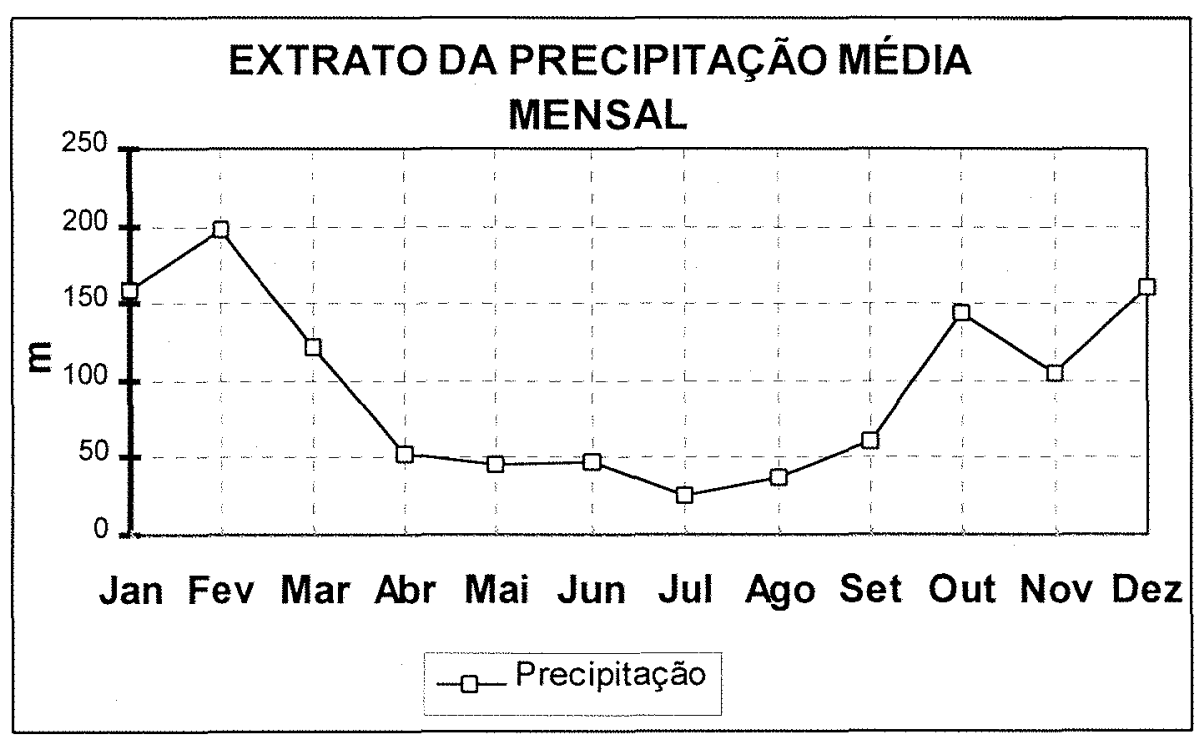

Figura 4 - Extrato da Precipitação média mensal calculado com dados médios do período entre 1917 e 1999 da região de Pirajú - SP (Fonte: Departamento de Física e Meteorologia ESALQ/USP). 


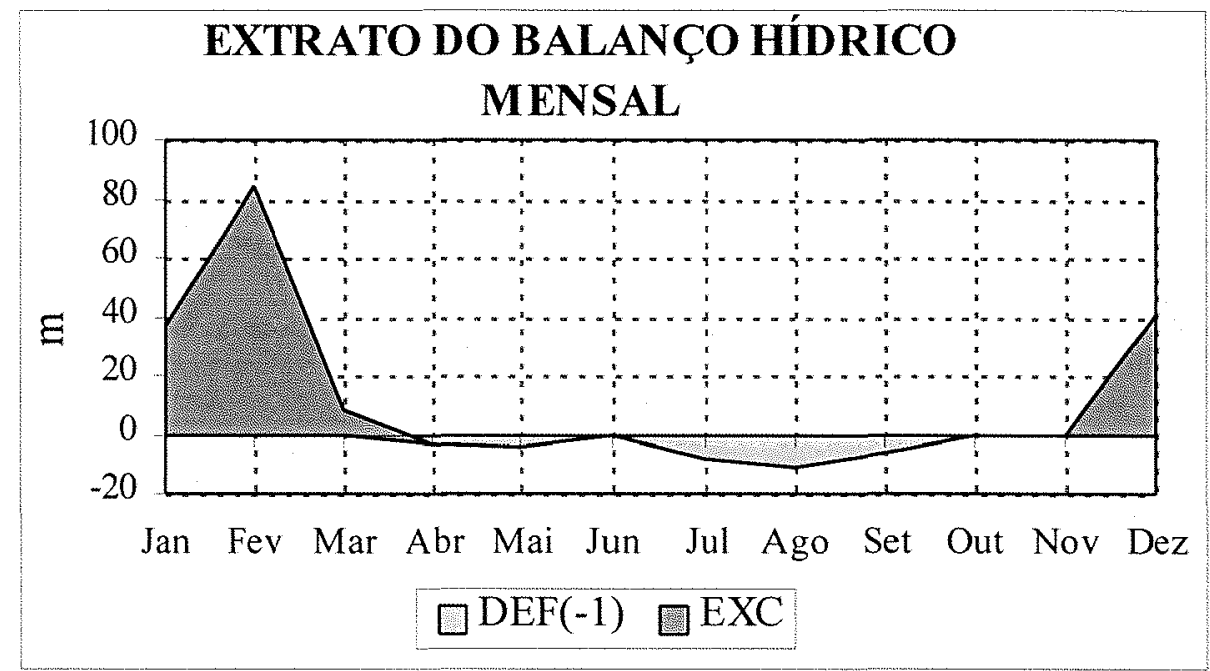

Figura 5 - Extrato do Balanço hídrico calculado com dados médios do período entre 1917 e 1999 da região de Pirajú - SP (Fonte: Departamento de Física e Meteorologia ESALQ/USP).

\section{Geologia da Área}

$\mathrm{Na}$ área estudada, ocorrem derrames de lavas básicas, ácidas pertencentes a Formação Serra Geral e intrusivas associadas, além de sedimentos pré e pós vulcânicos, representados principalmente, pelas formações Botucatu (Juro-Cretáceo) e Bauru (Cretáceo Superior). No topo do planalto basáltico, entre Sarutaiá e Fartura e ao longo do rio Paranapanema, afloram os arenitos da Formação Botucatu, que constituem os principais sedimentos pré-vulcânicos da área estudada.

Localmente, os sedimentos pré-vulcânicos são representados, também, pelas formações Estrada Nova (Corumbataí, Permiano Superior) e Pirambóia (Triássico Inferior), cujo contato se observa na subida da Serra da Fartura, em direção a Pirajú, devido a falhamentos escalonados, os quais originaram blocos que constituem a frente desta serra (Fúlfaro \& Suguio, 1974).

Os diques aflorantes na área, orientam-se segundo um sistema de falhas e fraturas de direção NW-SE que afetou toda a região (Fúlfaro \& Suguio, 1974). São, 
praticamente verticais, sendo seus contatos laterais, às vezes, de difícil distinção podendo passar, localmente, a pequenos sills (Figura 6).

A atividade tectônica ocorrida na área estudada, provocou o basculamento das rochas vulcânicas e sedimentares aflorantes (Fúlfaro \& Suguio, 1974). Nas proximidades das intrusivas, as rochas sedimentares podem apresentar altos mergulhos, juntamente com um leve metamorfismo de contato, representado por um "endurecimento" dos estratos (Fúlfaro \& Suguio, 1967), como é verificado entre a cidade de Fartura e Sarutaiá, onde ocorrem derrames ácidos no topo de sedimentos, cortados por diques de direção NE.

Como o objetivo de estudo deste trabalho são as rochas vulcânicas ácidas, citaremos um dos primeiros autores que descreveram tais tipos de rochas. Sartori \& Maciel Filho (1983), observaram que os derrames ácidos, ocorrem principalmente, ao longo do rio Paranapanema (Figura 6), podendo apresentar vesículas e/ou amígdalas. Esses derrames foram afetados por um sistema de falhas e fraturas de direção NW-SE, muitas das quais foram responsáveis pelos seus contatos com os derrames básicos e os sedimentos. Pequenas lentes de arenitos são freqüentes entre um derrame e outro.

As vulcânicas ácidas apresentam uma estrutura tabular bem definida, devido a presença de um sistema de juntas horizontais bem desenvolvidos.

Apresentam-se, freqüentemente, alterados sendo que, as cores de alteração variam de vermelho-amarronzado a cinza-esbranquiçado.

Raposo (1987), determinou que a espessura máxima encontrada para os derrames ácidos foi de, aproximadamente, 180 metros em Pirajú.

As rochas, neste caso, apresentam texturas que variam de fraca a fortemente porfirítica. Essas rochas são classificadas, principalmente, como riólitos e riodacitos e pertencem ao tipo Chapecó. 


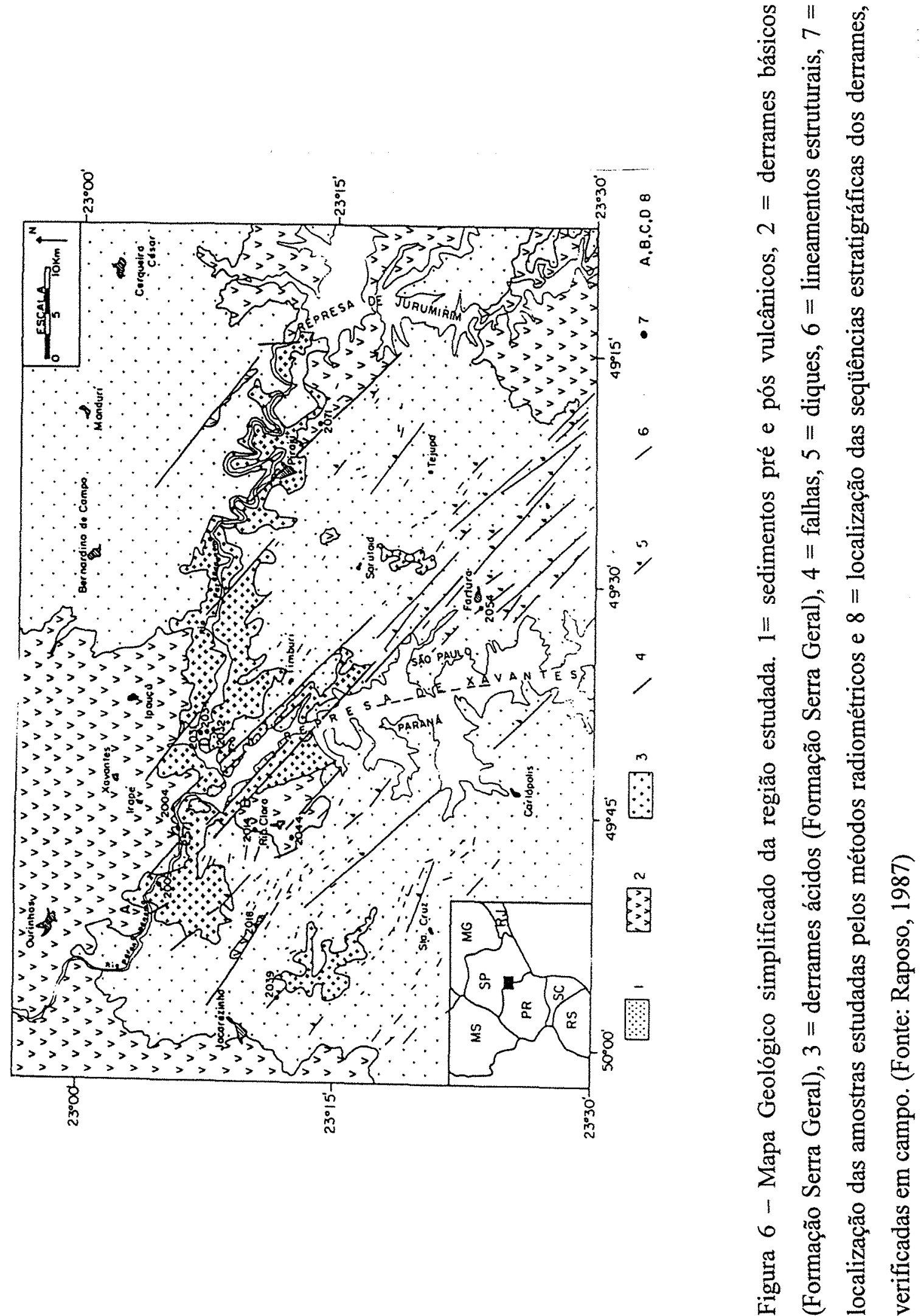

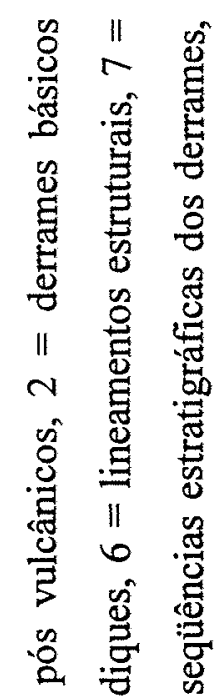




\subsection{Trabalho de Campo:}

A metodologia empregada neste trabalho desenvolveu-se em duas etapas, sendo uma de campo e outra de laboratório.

$\mathrm{Na}$ viagem ao campo, foi realizado o reconhecimento geral da área, envolvendo conceitos geológicos, geomorfológicos e pedológicos. Para tais observações, utilizou-se o mapa geológico apresentado por Raposo (1987).

Com base nestas observações, selecionou-se uma topossequência que recebeu a denominação de Topossequência Timburi. Tal designação se refere a nomes regionais. Assim, nesta topossequência foram coletados 5 perfis, P1, P2, P3, P4 e P5 sendo P1 e P5 perfis completos desde a rocha até o horizonte superior do solo e os demais apenas as camadas de rocha alterada juntamente com os perfis do solo.

As camadas de rocha alterada receberam a denominação de $1.2 ; 1.3 ; 1.4$; 2.3;.2.4 e assim sucessivamente até $5.2 ; 5.3$ e 5.4.

Quanto as amostragens, procurou-se sempre coletar mais do que uma amostra num mesmo estágio de alteração, para evitar que passassem desapercebidos detalhes não visualizados no campo.

Os aspectos macromorfológicos, como cor, estrutura, distribuição das raízes, porosidade e consistência do solo foram identificados de acordo com Lemos \& Santos (1996).

Após a descrição morfológica detalhada dos perfis, foram coletadas amostras para análises físicas, químicas e mineralógicas de todos os horizontes e amostras indeformadas e orientadas dos principais horizontes e das transições entre eles.

\subsection{Trabalho de Laboratório :}

No presente trabalho, a metodologia seguida no laboratório abrangeu, uma sequência básica de análises: 1) Análise física (granulometria), 2) Análises químicas (fluorescência de raios-X, análises químicas e análises de ataque sulfúrico, ferro livre - amorfo e cristalino), 3) Análises mineralógicas (microscopia óptica, difração de raios-X, microscopia eletrônica de varredura (MEV) e micromorfologia). 
As amostras de solo foram secas ao ar, destorroadas com um martelo de borracha e passadas em peneira $\mathrm{n}^{0} 10$ (malha de $2 \mathrm{~mm}$ ), obtendo a fração terra fina seca ao ar (TFSA) onde foram realizadas as análises granulométricas. As amostras de solo utilizadas para as análises químicas e mineralógicas foram passadas em peneira $\mathrm{n}^{0} 18$ (malha de $1 \mathrm{~mm}$ ).

\subsubsection{Análise Física}

A granulometria foi determinada por peneiramento (cascalho e calhaus) e pelo método do densímetro baseado na sedimentação de partículas (areia, silte e argila), conforme Embrapa (1997).

Posteriormente a areia foi fracionada em areia muito grossa, grossa, média, fina, muito fina, silte e argila.

\subsubsection{Análise Química}

\subsubsection{Fluorescência de raios-X}

As amostras de rochas e de seus diferentes níveis de alteração, foram submetidas a análises por Fluorescência de raios-X, determinando-se $\mathrm{SiO}_{2}, \mathrm{Al}_{2} \mathrm{O}_{3}, \mathrm{FeO}$, $\mathrm{CaO}, \mathrm{MgO}, \mathrm{MnO}, \mathrm{TiO}_{3}, \mathrm{Na}_{2} \mathrm{O}, \mathrm{K}_{2} \mathrm{O}$ e $\mathrm{P}_{2} \mathrm{O}_{5}$ nos laboratórios do Instituto de Geociências e Ciências Exatas da Universidade Estadual Paulista Júlio de Mesquita Filho - UNESP.

\subsubsection{Análise química}

Após a separação das frações do material, foi separado $10 \mathrm{~g}$ de material de granulometria menor que 2 milímetros para análise de $\mathrm{pH}$ em água, $\mathrm{KCl}$ e $\mathrm{CaCl}_{2}$. O carbono total das amostras de solo foi determinado por combustão e o carbono orgânico através do método do colorímetro.

As bases $\left(\mathrm{Ca}^{2+}, \mathrm{Mg}^{2+} \mathrm{e} \mathrm{K}^{+}\right)$foram extraídas por resina trocadora de íons e determinadas por espectofotometria de absorção atômica $\left(\mathrm{Ca}^{2+}, \mathrm{Mg}^{2+}\right)$ e por fotometria de emissão $\left(\mathrm{K}^{+}\right)$. $\mathrm{O} \mathrm{Na}^{+}$foi determinado pelo método Mehlich 1 e o $\mathrm{H}^{+}+\mathrm{Al}^{3+}$ extraído em acetato de cálcio $1 \mathrm{~N} \mathrm{a} \mathrm{pH} 7$ e determinado por titulação. 
A capacidade de troca catiônica (CTC) foi determinada pelo método direto, saturando-se a amostra com acetato de cálcio e posteriormente quantificando-se o $\mathrm{Ca}^{2+}$ retido e extraído do complexo de troca. A porcentagem de saturação por bases (V\%) foi calculada a partir da razão da soma de bases (S) pela CTC e multiplicando-se por 100 .

Os micronutrientes $\mathrm{Cu}, \mathrm{Fe}, \mathrm{Mn}$ e $\mathrm{Zn}$ foram extraídos com DTPA e determinados por espectrofotometria. O boro foi analisado usando-se solução de cloreto de bário.

As determinações seguiram as metodologias recomendadas conforme Embrapa (1997).

\subsubsection{Ferro livre (amorfo e cristalino)}

O ferro foi extraído com ditionito-citrato-bicarbonato (DCB) e oxalato de amônio conforme descrito em Camargo et al. (1986).

O ferro cristalino foi estimado pela diferença do ferro (ditionito) menos o ferro (oxalato).

\subsubsection{Ataque sulfúrico e determinação dos índices de intemperismo Ki e Kr}

A sílica foi extraída a partir do ataque alcalino a quente e o $\mathrm{Al}_{2} \mathrm{O}_{3}, \mathrm{Fe}_{2} \mathrm{O}_{3}$, $\mathrm{TiO}_{2}$ e $\mathrm{MnO}$ foram obtidos através de ataque sulfúrico a quente, conforme descrito em Camargo et al. (1986). A determinação da sílica foi feita por gravimetria, $\mathrm{Al}_{2} \mathrm{O}_{3}$ por titulação, $\mathrm{TiO}_{2}$ por colorimetria e $\mathrm{Fe}_{2} \mathrm{O}_{3}$ e $\mathrm{MnO}$ por espectrofotometria de absorção atômica.

O Ki foi calculado pela relação molecular entre a porcentagem de sílica e $\mathrm{Al}_{2} \mathrm{O}_{3}$ e o $\mathrm{Kr}$ segundo a relação molecular entre sílica e $\left(\mathrm{Fe}_{2} \mathrm{O}_{3}+\mathrm{Al}_{2} \mathrm{O}_{3}\right)$.

As análises físicas e químicas do solo foram feitas no Departamento de Solos e Nutrição de Plantas (ESALQ/USP).

\subsubsection{Análises Mineralógicas}




\section{Preparo das amostras}

As amostras dos solos e das alterações sofreram um tratamento prévio para eliminação do ferro e da matéria orgânica.

Inicialmente foi feita a oxidação da matéria orgânica com peróxido de hidrogênio a $30 \%$ e a remoção do ferro com citrato de sódio $3 \mathrm{M}$, bicarbonato de sódio $1 \mathrm{M}$ e ditionito de sódio. Finalmente a fração areia foi separada por peneiramento e o silte + argila foi separada por centrifugação a $700 \mathrm{rpm}$.

\subsubsection{Microscopia Óptica}

A microscopia óptica constitui a base de todas as observações e análises, tendo sido efetuada sobre lâminas delgadas.

O estudo petrológico - micromorfológico sobre lâminas delgadas permite uma caracterização dos constituintes mineralógicos, locais específicos de alteração e suas relações, a partir de amostras não perturbadas.

Os minerais possuem características ópticas específicas (birrefringência, pleocroísmo, clivagens, relevo, etc) que não apresenta problemas na determinação de minerais primários da rocha sã, o mesmo não ocorre quando são produtos de alteração, minerais neo-formados ou minerais de transformação, em especial os argilominerais, isto porque, apresentam-se muitas vezes associados a oxi-hidróxidos de Fe que mascaram seus caracteres ópticos próprios.

Para a descrição das lâminas delgadas dos litotipos presentes, em especial dos riodacitos, adotou-se os seguintes critérios:

* diâmetro máximo dos cristais

Quanto aos seus diâmetros máximos foram classificados em:

1) macrofenocristais $\rightarrow$ correspondem aos cristais cujo diâmetro máximo apresenta valores superior a $2 \mathrm{~mm}$. 
2) fenocristais $\rightarrow$ correspondem a cristais onde o valor do diâmetro máximo encontra-se no intervalo de $0,5 \mathrm{a} 2 \mathrm{~mm}$.

3) microfenocristais $\rightarrow$ correspondem a cristais onde o valor do diâmetro máximo atinge valores entre de 0,5 a $0,2 \mathrm{~mm}$

4) $\underline{\text { matriz }} \rightarrow$ quando o diâmetro máximo é inferior a $0,2 \mathrm{~mm}$.

Os critérios texturais adotados foram, o tamanho relativo dos cristais e o grau de cristalinidade.

*com base no tamanho relativo dos cristais e na quantidade de fenocristais presentes, foram identificadas as seguintes estruturas:

a) fortemente porfiritica $\rightarrow$ caracterizada por apresentar quantidades de fenocristais superiores a $20 \%$.

b) medianamente porfirítica $\rightarrow$ caracterizada por apresentar quantidades de fenocristais superiores a $10 \%$ e inferiores a $20 \%$.

c) porfirítica $\rightarrow$ caracterizada por apresentar quantidades de fenocristais superiores a $5 \%$ e inferiores a $10 \%$.

d) fracamente porfiritica $\rightarrow$ caracterizada por apresentar quantidades de no máximo $5 \%$ de fenocristais.

e) afirica $\rightarrow$ caracterizada pela ausência de fenocristais.

* quanto ao grau de cristalinidade e com base na proporção dos componentes cristalinos e vítreos presentes nas rochas foram identificadas as seguintes texturas (Barker, 1983).

1) hipocristalina $\rightarrow$ caracteriza-se pela quase totalidade de componentes cristalinos, podendo conter material vítreo em quantidade inferior a $2 \% \mathrm{em}$ volume.

2) hipovitrea $\rightarrow$ caracteriza-se pela predominância de material vitreo, embora contenham componentes cristalinos.

3) holovitrea $\rightarrow$ caracteriza-se pela quase totalidade de material vítreo.

$$
\text { * quanto a textura }
$$


1) subofiticas, caracterizam-se por apresentar cristais de plagioclásio e piroxênios de tamanhos, aproximadamente iguais, sendo o piroxênio parcialmente envolvido pelo plagioclásio

2) ofitica caracteriza-se pela ocorrência de piroxênio envolvido totalmente pelo plagioclásio.

\subsubsection{Análises por Difração de Raios- X}

As análises por difração de Raios-X constituem uma das primeiras etapas nas determinações mineralógicas (rocha, alterita e solo) ou aplicadas sobre fases separadas desses materiais.

O estudo da difração nos argilominerais é de suma importância e é um tipo de análise que se tornou rotineiro, quase obrigatório. A literatura referente ao assunto é vasta; entre vários trabalhos básicos sobre princípios, utilização do método e identificação das estruturas cristalinas, destacamos Dixon (1966); Brown \& Brindley (1980); Brindley (1966-1967); Gomes (1984); Victor et al (1998), entre outros.

A evolução nas técnicas de análise por difração de Raios-X, desde a preparação da amostra até estudos sobre a natureza, propriedades, interestratificações, etc, tem proporcionado inúmeras aplicações e resoluções no domínio das pesquisas de argilominerais.

A primeira etapa feita foi analisar a fração areia, a fração silte e a fração argila de acordo com Jackson (1956). Utilizou-se um difratômetro Philips com tubo de Cobre $(\mathrm{K} \alpha$ de $1,5418 \AA)$ com filtro de níquel.

A fração argila foi saturada com $\mathrm{K}^{+}$e $\mathrm{Mg}^{2+}$ e após o processo de saturação, confeccionou-se lâminas orientadas que posteriormente, foram submetidas a irradiação com raios-X no intervalo de $2 \theta$ de $3^{\circ}$ a $30^{\circ}$.

Sub-amostras de argila saturadas com $\mathrm{Mg}^{2+}$ foram solvatadas com etilenoglicol e outras sub-amostras de argila saturadas com $\mathrm{K}^{+}$foram submetidas a aquecimento de $350^{\circ}$ e $550^{\circ}$. Posteriormente estas amostras foram irradiadas para a verificação de possíveis alterações em suas distâncias basais. 
A fração silte, após a centrifugação a $700 \mathrm{rpm}$, foi exposta em lâminas que também foram submetidas a irradiação por difração de raios-X.

Após realizados os difratogramas os picos dos minerais foram identificados de acordo com Griffin (1971) e Jackson (1969).

A caolinita foi identificada por seus picos de difração a 7,14 - 7,29 $\AA$ e $3,49-3,53 \AA$, os quais desaparecem pelo aquecimento a $550^{\circ} \mathrm{C}$; a gibbsita, por seu pico a 4,85 e $4,30 \AA$ que desaparece a $350^{\circ} \mathrm{C}$; a mica, por seu pico de difração ao redor

de $10 \AA$, por não sofrer expansão com a solvatação quando tratada com etileno-glicol, e também por continuar presente na amostra por aquecimento a $550^{\circ}$ C. Esses procedimentos seguem sugestões de Brown (1961).

\subsubsection{Microscopia Eletrônica de Varredura (MEV)}

A principal vantagem do estudo com MEV é que podem ser obtidas micrografias diretamente de espécimes sólidos, com um poder de resolução (a mínima distância entre dois pontos dados de um espécime, para o qual é possivel diferenciar os sinais emitidos) e uma profundidade de foco consideravelmente melhores que aquelas obtidas com microscópio óptico de luz.

A microscopia eletrônica, permite visualizar (na rocha alterada e no solo) a morfologia dos constituintes mineralógicos e as relações existentes entre eles.

As amostras indeformadas foram submetidas ao exame por MEV marca Jeol modelo - 5600 LV, acoplado à microssonda "Noran", com detector de fluoreto de lítio. Para isso, amostras (fragmentos de rocha alterada) foram estudadas e selecionadas em função dos problemas levantados pela microscopia óptica nas lâminas. As amostras foram inicialmente coladas em suporte de metal com cola de prata e em seguida nebulizadas com ouro ou carbono em um evaporador "Deton Vacuum Desk II".

As análises ao microscópio eletrônico e por difratometria de raios-X foram efetuadas no Núcleo de Pesquisa em Geoquímica e Geofísica da Litosfera (NUPEGEL/ ESALQ/USP).

Quanto a utilização da microanálise pontual foi apenas qualitativa, objetivando confirmar os minerais os quais foram identificados pelo seu hábito, quando 
observados no microscópio de varredura, bem como identificar outros elementos e minerais que as análises precedentes não identificaram.

\subsubsection{Análises Micromorfológicas}

Estas amostras foram secas ao ar e antes da impregnação procedeu-se secagem em estufa a $45^{\circ} \mathrm{C}$ durante dois dias para prevenir a permanência de alguma umidade ainda restante. Para a impregnação, utilizou-se Resina Ortofitálica T208 mais Monômero de Estireno, juntamente com 3 gotas de endurecedor da marca Butanox, seguindo procedimento descrito por Hanrion (1976).

Após o endurecimento, as amostras foram cortadas, coladas em lâminas de vidro para microscopia e polidas em laminadora até próxima a espessura considerada adequada $(30 \mu \mathrm{m})$. O polimento final foi feito com pó de carborundum de granulometria cada vez mais fina, até que os grãos de quartzo apresentarem-se em tons amarelados/acinzentados, parâmetro considerado adequado nas seções delgadas.

As análises micromorfológicas e as fotomicrografias foram realizadas em fotomicroscópio petrográfico Zeiss no laboratório de micromorfologia do Departamento de Ciência do Solo da ESALQ/USP, seguindo critérios estabelecidos por Brewer (1976) e compilações realizadas por Castro (1989). 


\section{RESULTADOS E DISCUSSÃO}

\subsection{Morfologia}

Foram estudados 5 perfis, identificados como P1, P2, P3, P4 e P5, todos localizados na topossequência representada pela Figura 7. Suas descrições morfológicas encontram-se no APÊNDICE 1, sendo enfatizado neste capitulo apenas os principais atributos pertinentes à melhor caracterização e aos estudos de gênese dos diferentes horizontes nos perfis. Na Figura 8 estão reproduzidos os perfis P1, P2, P3, P4 e P5 e identificando todos os seus horizontes.

Os perfis representativos dos materiais, descritos e analisados na Topossequência Timburi, foram classificados de acordo com o Sistema Brasileiro de Classificação de Solos (Embrapa, 1999) como sendo um LATOSSOLO VERMELHO Distrófico típico.

\subsubsection{Perfil P1}

Trata-se de um perfil completo de alteração desde a rocha sã, passando para a rocha levemente alterada até o horizonte superficial do solo (a Figura $8 \mathrm{~A}$ ilustra o perfil completo de alteração e do solo). A espessura máxima dos horizontes neste perfil é de aproximadamente 3,80 metros.

O perfil situa-se na parte mais baixa da topossequência. O perfil é pouco profundo, tanto que a rocha sã aparece a 5 metros de profundidade. A amostragem foi realizada aproveitando-se o corte de estrada, sendo necessário apenas, sua limpeza e escarificação.

Sua cor varia de 2,5 YR3/4 (marrom avermelhado escuro) para 2,5 YR $3 / 6$ (vermelho escuro). 


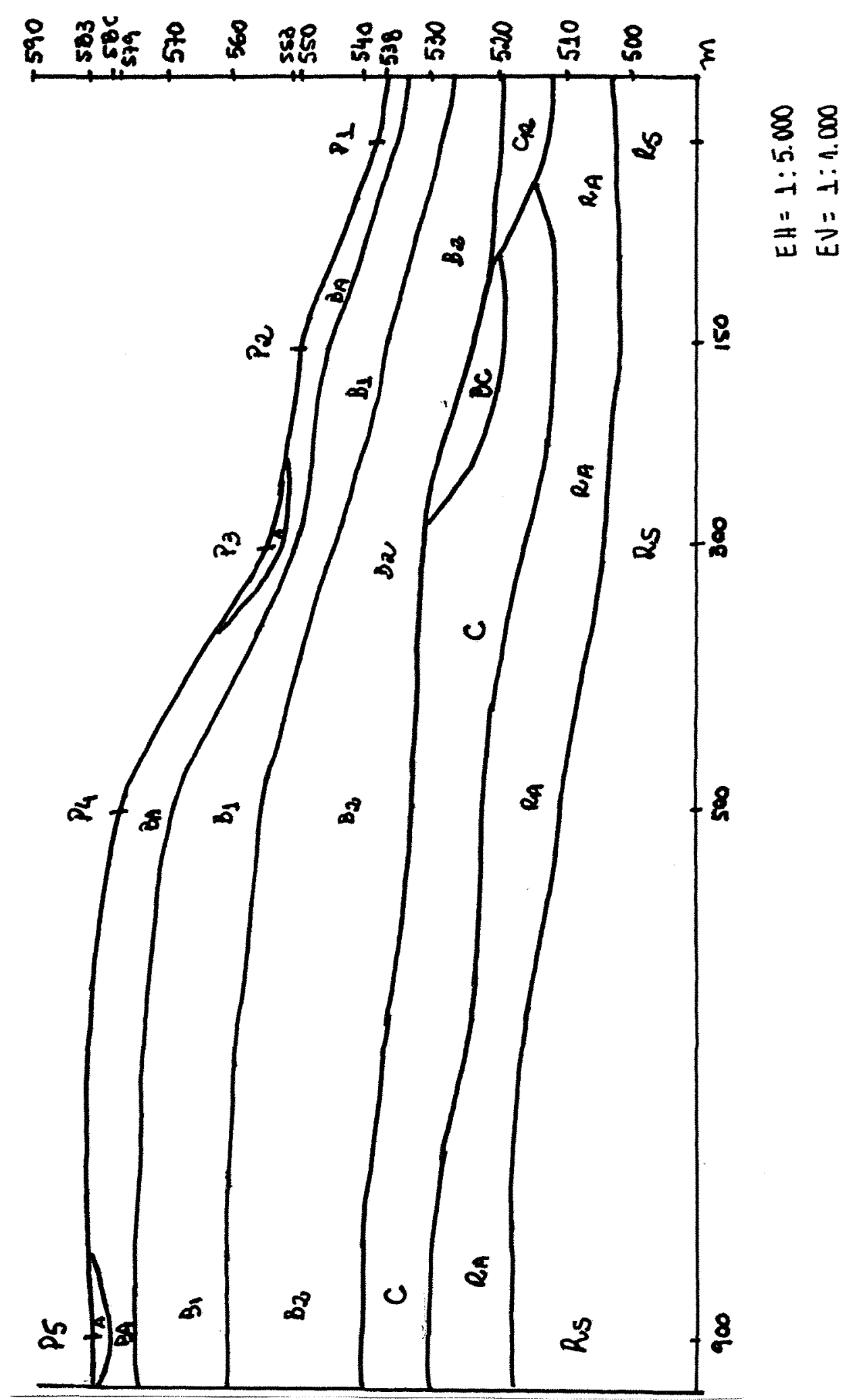

Figura 7 - Representação esquemática da topossequência estudada com a localização dos Perfis P1, P2, P3, P4 e P5 e a distribuição lateral e vertical dos diferentes horizontes. 
As classes texturais deste perfis são muito argilosa a média-argilosa no horizonte $\mathrm{Cr}$ e nas camadas de alteração vão desde uma textura média-arenosa para uma textura média-argilosa.

O material saprolítico é progressivamente manchado em tons acinzentados à medida que se aprofunda no perfil.

A Figura 9 indica detalhes da alteração, na interface rocha/alteração/ solo.

A presença de cerosidade ocorre apenas no horizonte B1, sendo esta classificada como sendo tipicamente de compressão.

A estrutura é composta por blocos subangulares e de grau fraco a medianamente desenvolvido e de estrutura grumosa de tamanho milimétrico ( 3 a $8 \mathrm{~mm}$ ) no horizonte A.

A presença de microagregados é comum em todos os horizontes, nódulos e litorrelíquias são encontrados nos horizontes B1 e B2.

Quanto a separação das fases de alteração foram identificadas de acordo com a "dureza" que estas apresentam, onde chamamos de fácies de rocha pouco alterada, fácies de rocha alterada e fácies de rocha muito alterada.

Neste perfil a fácies de rocha pouco alterada é caracterizada pelo início da alteração da rocha, conservando ainda as texturas e estruturas petrográficas. Apresenta leves modificações da cor original da rocha sã, exibindo tons amarelados à cinza amarelados. A rocha é bastante resistente ao contato com o martelo.

$\mathrm{Na}$ fácies de rocha alterada predomina cores amareladas e o material é bem mais friável. Os fenocristais de plagioclásio apresentam sinais marcantes de alteração, com coloração modificada.

$\mathrm{Na}$ fácies de rocha muito alterada as cores são mais acinzentadas. A estrutura foi toda destruída tornando-se uma rocha muito friável. Os plagioclásios estão coloridos de tons amarelados. A espessura máxima de toda essa sequiência de alteração é de aproximadamente 1,20 metro.

A rocha sã trata-se de um riodacito de coloração cinza-amarronzado, apresenta cristais euhédricos de feldspato plagioclásio e amígdalas preenchidas por 
quartzo, zeólitas, ou por goethita imersos em uma massa afanítica de coloração acinzentada.

\subsubsection{Perfil P2}

Para a coleta do perfil P2, o segundo da parte mais baixa para a mais alta da topossequência, aproveitou-se de um corte de estrada fazendo-se a limpeza do mesmo. Sua distância dista de $150 \mathrm{~m}$ a montante do primeiro perfil (Figura 8 B).

Classificou-se 5 horizontes de solo, com uma espessura de 4,30 metros, de textura muito argilosa, semelhante ao perfil P1. Sua cor varia no horizonte A de 2,5 YR 3/4 (marrom avermelhado escuro) para 2,5 YR 4/6 (vermelho) no horizonte B1, permanecendo com 2,5 YR 4/4 (marrom avermelhado) nos demais horizontes de solo.

Quanto a cerosidade, foi semelhante ao perfil P1, observada somente no horizonte B1 do solo. A estrutura típica de todo o perfil foi classificada como sendo blocos subangulares de grau pouco desenvolvido. Ocorre também a presença de nódulos argilosos e ferruginosos nos horizonte $\mathrm{B} 2, \mathrm{BC}$ e $\mathrm{C}$.

$\mathrm{O}$ horizonte $\mathrm{BC}$, apresenta maior quantidade de litorrelíquias (plagioclásios). $\mathrm{O}$ aspecto é maciço, com alguns domínios apresentando estrutura forte.

No horizonte $\mathrm{C}$, a abundância de plagioclásios e vesículas é comum. A estrutura é herdada da rocha, com domínios formados por agregados granulares pequenos. As variações na estrutura, cor e quantidade de minerais primários decomponíveis são gradativas em direção ao topo.

Abaixo do horizonte $\mathrm{C}$, as camadas de alteração foram classificadas como fácies de rocha alterada e muito alterada. $\mathrm{Na}$ fácies de rocha alterada os fenocristais de plagioclásio já apresentam sinais marcantes de alteração enquanto que na fácies de rocha muito alterada os plagioclásios já se encontram com uma coloração mais alaranjada, essa camadas exibem coloração arroxeada, a textura varia de argilosa a média-argilosa e a espessura atinge cerca de 1 metro.

\subsubsection{Perfil P3}


Este perfil situa-se na parte intermediária da topossequência a uma distância de $150 \mathrm{~m}$ a montantes do segundo perfil.

O perfil P3 foi dividido em 5 horizontes, apresentando um horizonte A, de coloração 2,5YR 3/4 (marrom avermelhado escuro), um horizonte de transição B/A e um horizonte B1 ambos de coloração 2,5YR 3/6 (vermelho escuro), horizonte B2 de 2,5YR 4/4 (marrom avermelhado) e um horizonte C de coloração 2,5YR 5/6 (vermelho), onde apresenta-se manchado, com pontuações milimétricas brancas a rosadas. Em profundidade aumentam os volumes rosados com aspecto litológico (Figura $8 \mathrm{C}$ ). A espessura máxima atingida é de aproximadamente 3,45 metros.

A textura geral dos horizontes do solo corresponde a uma textura muito argilosa, o que comprova ser semelhante com os demais perfis descritos anteriormente e a estrutura é formada por blocos subangulares pouco desenvolvidos, ocorre também a presença de microagregados ligados a pedotúbulos.

Neste perfil observa-se as fácies de rocha alterada, onde o material é bem mais friável. Os fenocristais de plagioclásio já apresentam sinais marcantes de alteração, com coloração modificada.

$\mathrm{Na}$ fácies de rocha muito alterada deste perfil, observa-se que as cores são um pouco mais avermelhadas que a da fácies anterior e a estrutura é bem mais friável. A estrutura de ambas as fácies variam de média argilosa a argilosa e a espessura atinge cerca de 1,50 metros.

A rocha sã exibe coloração amarronzada, apresentando auréolas de alteração em tons avermelhados que começam a se difundir do fundo matricial, provavelmente esta coloração é dada pela alteração de piroxênios e magnetita. A matriz da rocha é afanítica, ocorrendo microfenocristais de plagioclásio e vesículas preenchidas por quartzo e goethita.

\subsubsection{Perfil P4}

Localiza-se na meia encosta da topossequência, a uma distância de $200 \mathrm{~m}$ a montante do terceiro perfil (Figura 8 D). 
Dos perfis analisados, este é o que apresenta a maior espessura de alteração (aproximadamente $3 \mathrm{~m}$ ). Os horizontes de solo classificam-se como B/A, Bl e B2, onde, a coloração dos horizontes varia de 2,5YR 3/6 (vermelho escuro) a 2,5 YR 4/6 (vermelho), com uma espessura de 4,46 metros e textura variando de argilosa nas camadas de alteração gradando para muito argilosa em direção ao topo do perfil.

A presença de cerosidade ocorre apenas no horizonte $\mathrm{B} / \mathrm{A}$ em algumas faces dos agregados subangulares.

Abaixo desta camada, o material tem estrutura maciça com porções microgranulares e alguns agregados subangulares de grau pouco desenvolvido. Presença de nódulos argilosos e ferruginosos mais abundantes na base do horizonte B2.

Neste perfil foi possível notar uma fácies de rocha alterada onde as estruturas litológicas são reconhecíveis junto ao sistema de fraturamento original da rocha. As cores variam do acinzentado a uma coloração mais rosada. Os plagioclásios apresentam-se coloridos da mesma cor da matriz da rocha.

Logo acima desta camada ocorrem duas fácies de rocha muito alterada (4.6 e 4.7) com coloração mais avermelhada que a anterior. Nota-se apenas uma diferença marcante entre essa duas alterações, na fácies 4.6 ocorre uma maior quantidade de pedotúbulos preenchidos totalmente por microagregados (figura 10).

\subsubsection{Perfil P5}

Novamente, trata-se de um perfil completo de alteração desde a rocha levemente alterada até o horizonte superficial do solo. Situa-se na parte mais alta da topossequência a uma distância de $400 \mathrm{~m}$ do perfil anterior. $\mathrm{O}$ perfil é um pouco mais profundo que o perfil $\mathrm{P} 1$, tanto que a rocha sã aparece a 6 metros de profundidade. A amostragem foi realizada aproveitando-se o corte de estrada, sendo necessário apenas a sua limpeza.

A Figura $8 \mathrm{E}$ ilustra o perfil completo de alteração desde a rocha levemente alterada até o horizonte superficial do solo.

O perfil apresenta um horizonte superficial A e um horizonte de transição B/A de coloração 2,5YR 3/4 (marrom avermelhado escuro). Os horizontes B1, B2 e C 
apresentam uma coloração de 2,5YR 4/4 (marrom avermelhado) e textura muito argilosa. A espessura máxima dos horizontes atinge neste perfil 5,30 metros.

No horizonte $\mathrm{C}$ a textura passa a ser argilosa, apresentando saprolito de coloração marrom amarelado (10YR 6/8) para marrom avermelhado (2,5YR 5/4).

A estrutura típica do perfil corresponde a uma estrutura microgranular com presença de nódulos argilosos e ferruginosos de tamanho centimétricos.

Em relação as fácies de alteração podemos classifica-las como a fácies de rocha pouco alterada, caracterizada pelo início de alteração da rocha. Apresenta leves modificações da cor original da rocha sã, exibindo tons amarelados à cinza amarelados.

$\mathrm{Na}$ fácies de rocha alterada predominam cores amareladas e o material é bem mais friável. Os fenocristais de plagioclásio apresentam sinais marcantes de alteração, com coloração modificada.

$\mathrm{Na}$ fácies de rocha muito alterada as cores são mais acinzentadas. A estrutura foi toda destruída tornando-se um material muito friável.

A espessura máxima atingida pela rocha alterada é de 1,20 metros.

A rocha sã exibe coloração esverdeada, matriz fina, presença de pequena quantidade de microfenocristais de plagioclásio. O que apresenta-se bem visível são amígdalas de tamanhos variados chegando a atingir até $7 \mathrm{~cm}$ e totalmente preenchidas principalmente por quartzo e algumas por zeólitas. Estas amígdalas apresentam auréolas de alteração de tonalidade avermelhada, podendo ser explicadas pela alteração de piroxênios e/ou magnetita os quais podem dar origem a esta coloração. 

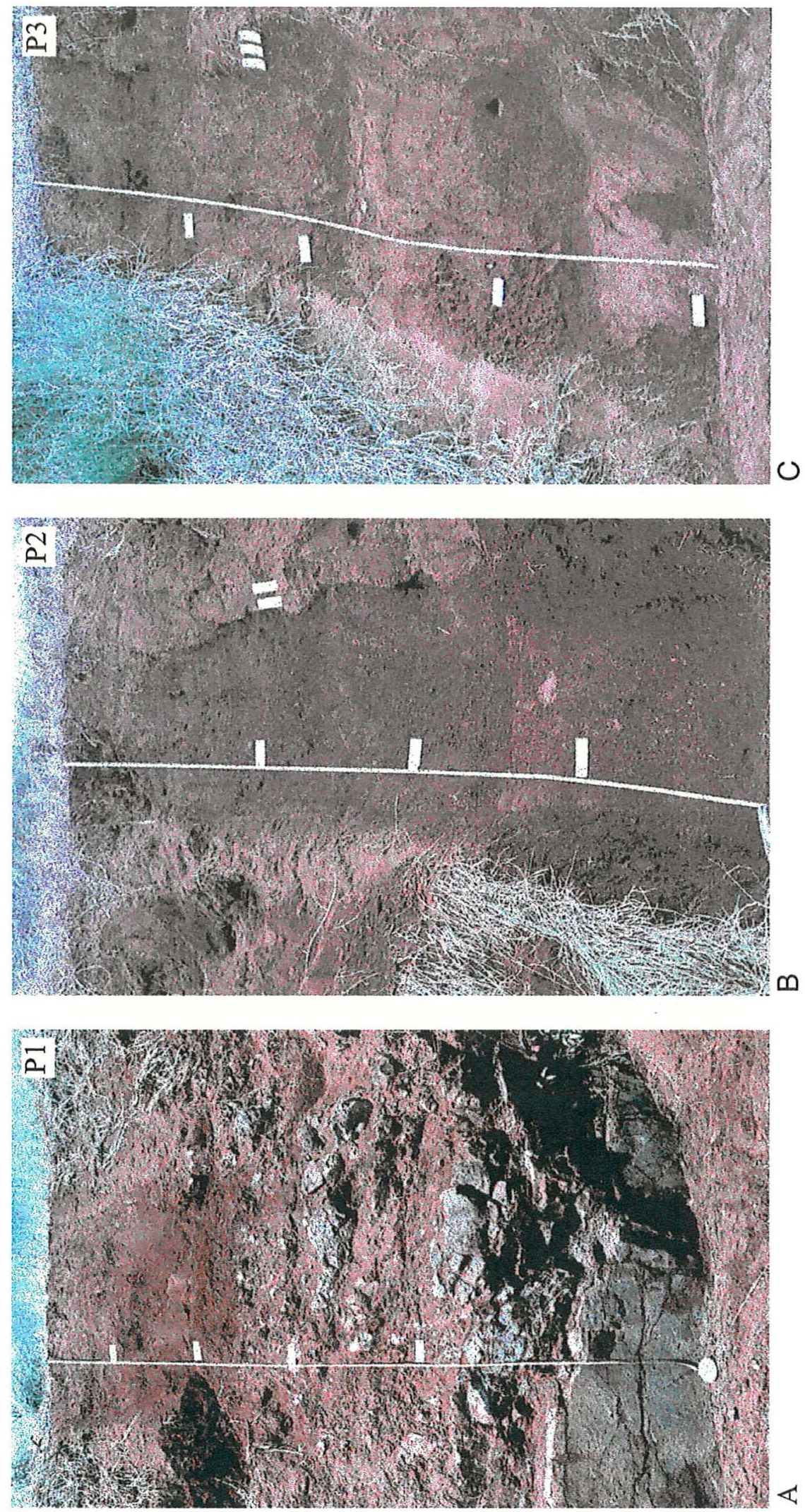

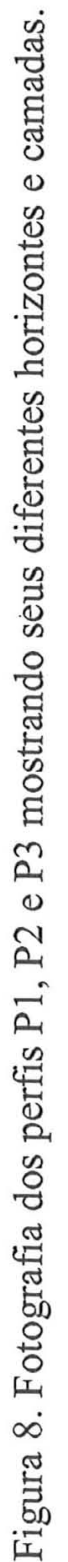




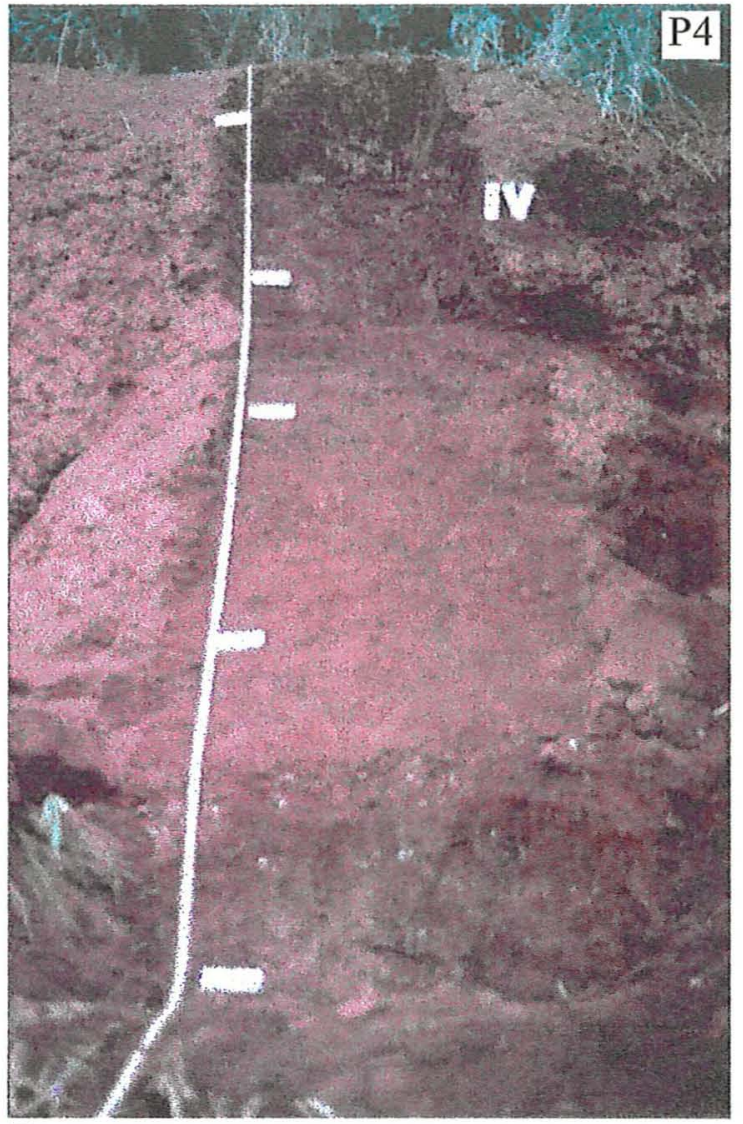

D

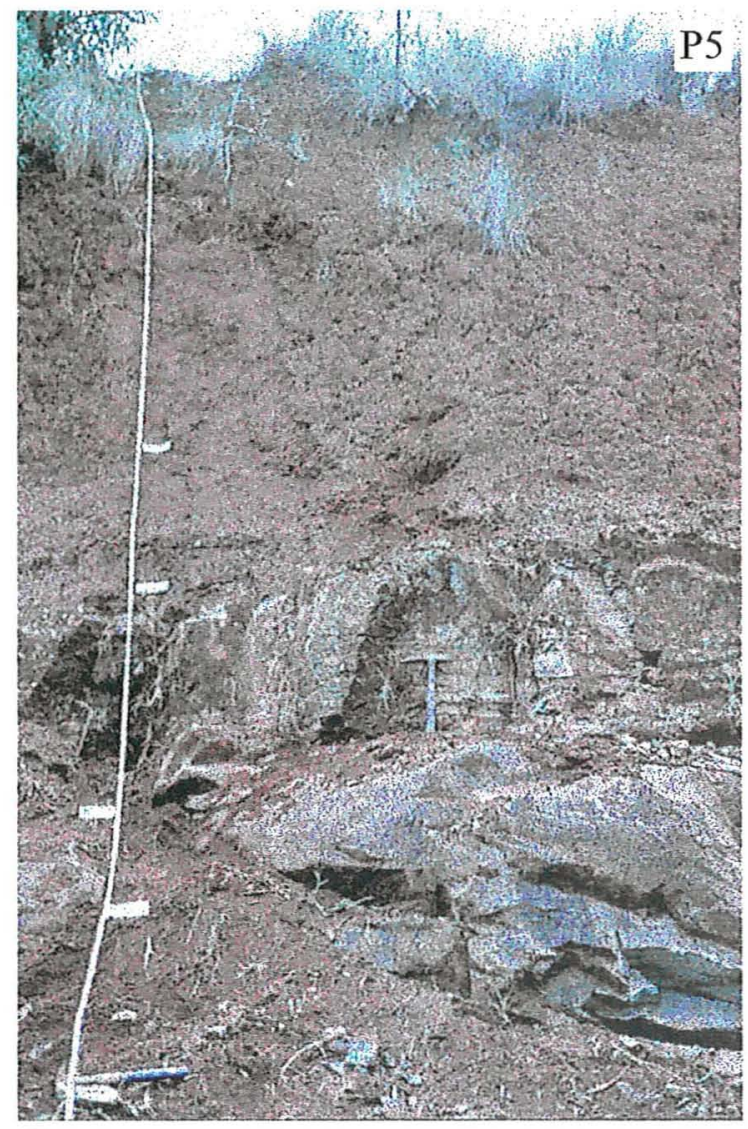

Continuação. Fotografia dos Perfis P4 e P5 mostrando os diferentes horizontes e camadas. 


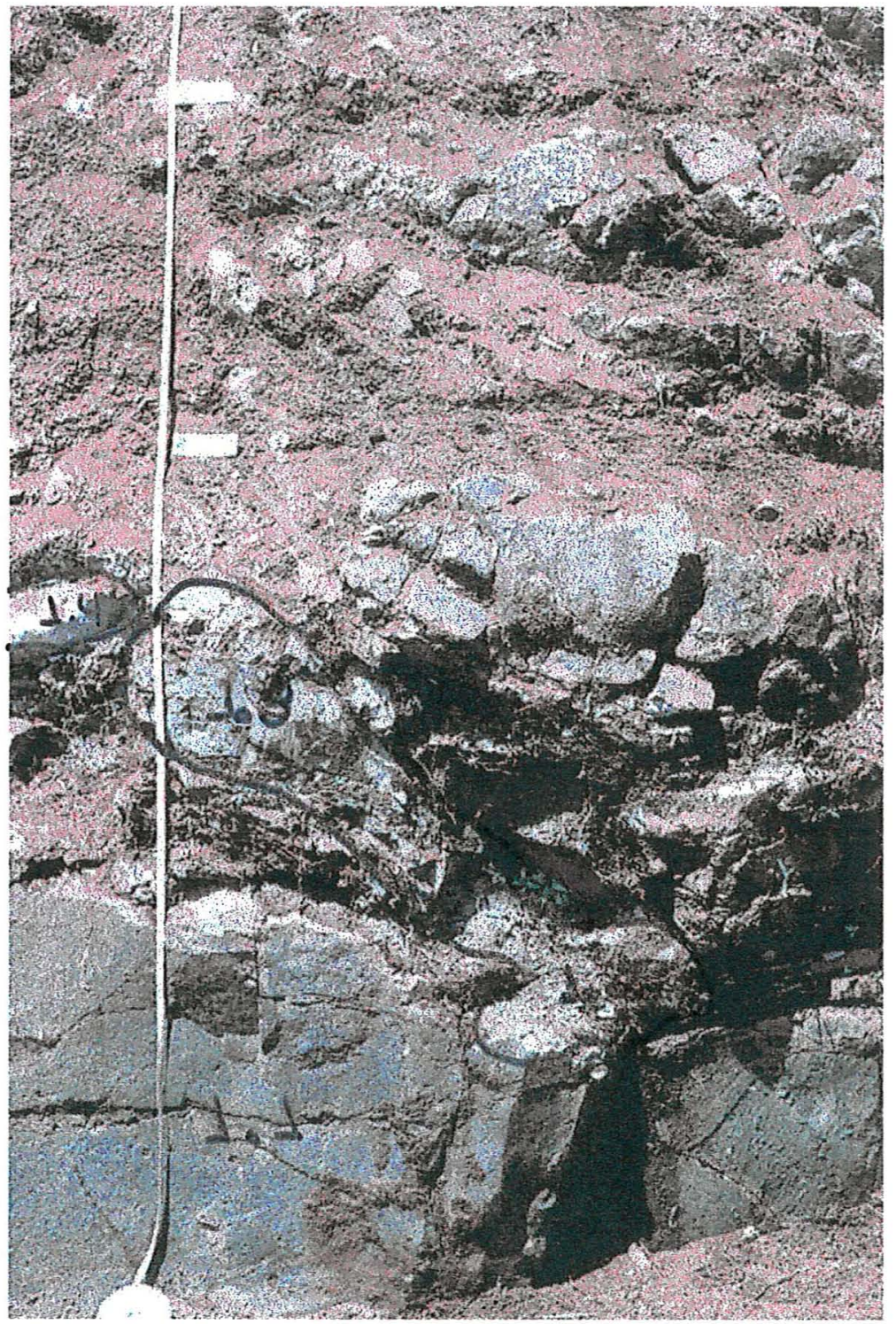

Figura 9. Detalhe das fases de alteração do Perfil P1. 


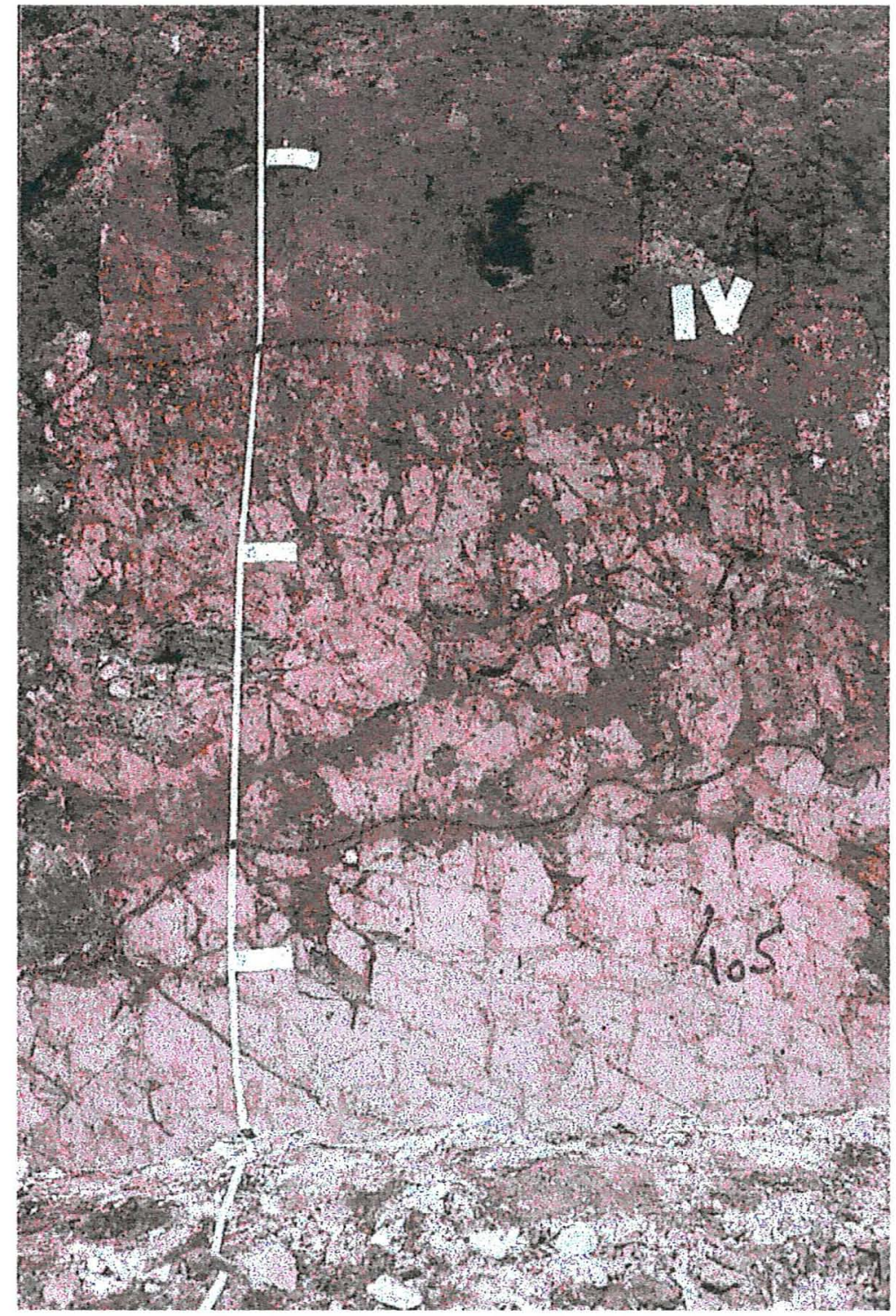

Figura 10. Detalhe das fases de alteração do Perfil P4. 
A seguir, evidências físicas, químicas, mineralógicas, micromorfológicas e submicroscópicas serão agrupadas e integradas dentro do possível, objetivando elucidar os diferentes mecanismos envolvidos na alteração dos minerais e da rocha.

\subsection{Evidências físicas}

\subsubsection{Granulometria}

A análise granulométrica dos perfis P1, P2, P3, P4 e P5 encontra-se na Tabela 1. Nota-se teores baixos a médios de areia nos horizontes de solo ( $1 \%$ a $32 \%)$, baixos de silte (menores que 16\%) e elevados de argila (maiores que 54\%). Entretanto, nos horizonte de alteração observam-se intervalos amplos de variação para as três frações granulométricas.

No entanto se observa que quando comparado os valores das alterações com o solo, nota-se uma diminuição da fração silte e um incremento da fração argila.

Ocorre também uma redução no conteúdo de argila com a profundidade para os horizontes de alteração da rocha, que associado ao aumento no conteúdo de areia total e ao conteúdo de silte, pode-se sugerir que as fácies de alteração possa estar fornecendo argila proveniente da degradação de minerais primários facilmente decomponíveis e presentes na fração areia, entre eles os plagioclásios e piroxênios facilmente identificáveis.

\subsection{Evidências Químicas}

\subsubsection{Análises químicas e análises por ataque sulfúrico}

\section{Análises químicas}

As propriedades químicas determinadas incluíram: matéria orgânica, reação do solo $(\mathrm{pH})$, bases trocáveis $(\mathrm{SB})$, Valor $(\mathrm{V})$, capacidade de troca cationica à $\mathrm{pH}$ $7\left(\mathrm{CTC}_{7}\right)$ e saturação em $\mathrm{Al}$.

Os dados obtidos para os perfis P1, P2, P3, P4 e P5 encontram-se na Tabela 2. Os 5 perfis analisados são classificados como sendo solos ácidos com $\mathrm{pH}$ em água variando de 4,0 a 4,9 . 
Tabela 1 - Propriedades físicas dos solos da Topossequência Timburi.

\begin{tabular}{|c|c|c|c|c|c|c|c|c|c|c|}
\hline \multirow[b]{2}{*}{$\mathbf{H z}$} & \multirow[b]{2}{*}{$\overline{\mathrm{MG}}$} & \multicolumn{2}{|c|}{$\begin{array}{c}\text { AREIA } \\
(\%)\end{array}$} & \multirow[b]{2}{*}{$\bar{F}$} & \multirow[b]{2}{*}{$\overline{\mathrm{MF}}$} & \multirow[b]{2}{*}{ TOT } & \multirow[t]{2}{*}{$\begin{array}{l}\text { SILTE } \\
(\%)\end{array}$} & \multirow{2}{*}{$\begin{array}{c}\text { ARGILA } \\
(\%)\end{array}$} & \multirow[t]{2}{*}{$\begin{array}{c}\text { FLOCULA } \\
\text { ÇÃOO } \\
(\%)\end{array}$} & \multirow[t]{2}{*}{$\begin{array}{c}\text { CLASSE } \\
\text { DE } \\
\text { TEXTURA }\end{array}$} \\
\hline & & $\bar{G}$ & $\bar{M}$ & & & & & & & \\
\hline $\mathrm{P} 1 \mathrm{~B} / \mathrm{A}$ & - & - & 2,0 & 5 & 2 & 9,0 & 15,0 & 76 & 100 & m.arg \\
\hline P1B1 & - & - & - & 1 & 1 & 2,0 & 15,0 & 83 & 100 & m.arg \\
\hline P1B2 & - & - & - & - & 1 & 1,0 & 15,0 & 84 & 100 & m.arg \\
\hline P1CR & - & 1,0 & 1,0 & 4 & 2 & 8,0 & 15,0 & 77 & 100 & m.arg \\
\hline $\mathrm{P1} .4$ & 8,0 & 11,0 & 12,0 & 15 & 6 & 52,0 & 16,0 & 32 & 100 & md-arg \\
\hline P1.3 & 25,0 & 10,0 & 10,0 & 12 & 7 & 64,0 & 17,0 & 19 & 100 & md-ar \\
\hline P1.2 & 18,0 & 7,0 & 10,0 & 17 & 7 & 59,0 & 18,0 & 23 & 100 & md-ar \\
\hline $\mathbf{P} 2 \mathrm{~A} / \mathrm{B}$ & - & - & 1,0 & 2 & - & 3,0 & 15,0 & 82 & 100 & m.arg \\
\hline P2B1 & - & - & 1,0 & 4 & 4 & 9,0 & 9,0 & 82 & 100 & m.arg \\
\hline P2B2 & - & - & 1,0 & 5 & 2 & 8,0 & 12,0 & 80 & 100 & m.arg \\
\hline P2BC & - & 1,0 & 2,0 & 11 & 11 & 25,0 & 2,0 & 73 & 100 & m.arg \\
\hline P2C & 1,0 & 1,0 & 4,0 & 15 & 11 & 32,0 & 8,0 & 60 & 100 & m.arg \\
\hline P2.5 & - & - & 1,0 & 1 & - & 2,0 & 42,0 & 56 & 100 & arg \\
\hline P2.4 & 1,0 & 2,0 & 5,0 & 14 & 4 & 26,0 & 40,0 & 34 & 100 & md-arg \\
\hline P2.3 & 7,0 & 3,0 & 6,0 & 14 & 8 & 38,0 & 21,0 & 41 & 100 & arg \\
\hline P3A & - & - & 1,0 & 3 & 1 & 5,0 & 13,0 & 82 & 100 & m.arg \\
\hline$\overline{\mathrm{P} 3 \mathrm{~B} / \mathrm{A}}$ & - & - & 1,0 & 3 & 3 & 7,0 & 13,0 & 80 & 100 & m.arg \\
\hline P3B1 & - & 1,0 & 1,0 & 6 & 3 & 11,0 & 9,0 & 80 & 100 & m.arg \\
\hline$\overline{\text { P3B2 }}$ & - & 1,0 & 1,0 & 10 & 14 & 26,0 & 2,0 & 72 & 100 & m.arg \\
\hline$\overline{P 3 C}$ & 1,0 & 2,0 & 4,0 & 9 & 6 & 22,0 & 6,0 & 72 & 100 & m.arg \\
\hline P3.5 & - & - & 1,0 & I & T & 3,0 & 58,0 & 39 & 100 & $\overline{\arg }$ \\
\hline P3.4 & 14,0 & 6,0 & 5,0 & 5 & 2 & 32,0 & 44,0 & 24 & 100 & md-ar \\
\hline
\end{tabular}


Continuação da tabela 1 - Propriedades físicas dos solos da Topossequência Timburi.

\begin{tabular}{|c|c|c|c|c|c|c|c|c|c|c|}
\hline P4A/B & - & - & - & 1 & 2 & 3,0 & 13,0 & 84 & 100 & m.arg \\
\hline P4B1 & - & - & 1,0 & 6 & 4 & 11,0 & 9,0 & 80 & 100 & m.arg \\
\hline P4B2 & - & - & 2,0 & 9 & 5 & 16,0 & 4,0 & 80 & 100 & m.arg \\
\hline P4.7 & - & 1,0 & 3,0 & 7 & 4 & 15,0 & 39,0 & 46 & 100 & arg \\
\hline P4.6 & 3,0 & 4,0 & 7,0 & 11 & 4 & 29,0 & 35,0 & 36 & 100 & arg \\
\hline P4.5 & 1,0 & 6,0 & 13,0 & 22 & 6 & 48,0 & 7,0 & 45 & 100 & arg \\
\hline \multicolumn{10}{|c|}{} \\
\hline \multicolumn{10}{|c|}{} \\
\hline P5A & - & 1,0 & 2,0 & 9 & 4 & 16,0 & 8,0 & 76 & 100 & m.arg \\
\hline P5A/B & - & - & 1,0 & 8 & 4 & 13,0 & 7,0 & 80 & 100 & m.arg \\
\hline P5B1 & - & 1,0 & 1,0 & 8 & 3 & 13,0 & 11,0 & 76 & 100 & m.arg \\
\hline P5B2 & - & - & 1,0 & 7 & 5 & 13,0 & 9,0 & 78 & 100 & m.arg \\
\hline P5C & 1,0 & 2,0 & 3,0 & 15 & 9 & 30,0 & 16,0 & 54 & 100 & arg \\
\hline P5.4 & 15,0 & 6,0 & 7,0 & 17 & 5 & 50,0 & 18,0 & 32 & 100 & md-arg \\
\hline P5.3 & 35,0 & 11,0 & 14,0 & 13 & 5 & 78,0 & 8,0 & 14 & 100 & ar \\
\hline P5.2 & 40,0 & 14,0 & 14,0 & 11 & 5 & 84,0 & 8,0 & 8 & 100 & ar \\
\hline
\end{tabular}

\section{Metodologia : Método do densímetro}

\section{Classes de Diâmetro (mm):}

Com 5 frações de areia: Muito Grossa $=2-1$; Grossa $=1-0,5 ;$ Média $=0,5-0,25$; Fina $=0,25-0,10$; Muito Fina $=0,10-0,05$.

Total $=2-0,05 ;$ Silte $=0,05-0,002 ;$ Argila total $<0,002$; Com duas frações de areia:

Grossa $=2-0,25 ;$ Fina $=0,25-0,05$.

\section{Classe de Textura:}

Até 14\% - arenosa : ar.; 15 -24\% - média-arenosa: md-ar.; 25-34\% - média-argilosa: md-arg.;

Obs: (-) elemento não analisado ou valor "zero" no resultado.

$1.2 ; 1.3 ; 1.4 ; 2.3 ; 2.4 \ldots . .5 .4$ - correspondem as fácies de alteração da rocha derivada do riodacito.

$1.1 ; 3.1$ e 5.1 - correspondem a rocha sã (riodacito) 
$\mathrm{O} \mathrm{pH}$ em $\mathrm{KCl}$ foi inferior ao $\mathrm{pH}$ em água, resultando em valores de $\Delta \mathrm{pH}$ negativo. Percebe-se assim, que mesmo sendo um solo evoluído há predominância de cargas negativas.

Em relação a matéria orgânica, este solo não possui teores elevados devido as condições de vegetação e relevo. A vegetação não é densa, não havendo, portanto, grandes incrementos de material orgânico.

O relevo da topossequência estudada por ser bastante inclinado, favorece o desenvolvimento da erosão. Esse processo erosivo ocasiona perdas da camada superficial do solo, mais rica em matéria orgânica, o que justifica a ausência de horizonte $\mathrm{A}$ em alguns perfis.

Em relação aos cátions trocáveis básicos, o sódio $(\mathrm{Na})$ foi o único não determinado na análise química, isto porque o sódio é altamente solúvel e porque todos os perfis encontram-se numa zona bem drenada.

Quanto ao teor de potássio $(\mathrm{K})$, pode-se perceber que seu teor decresce com a profundidade do solo, exceto no perfil P4.

$\mathrm{Na}$ tabela observa-se que os teores de cálcio $(\mathrm{Ca})$ permanecem constantes no perfil P2. Nos perfis P1 e P5 os teores desse elemento diminuem com a profundidade do solo. Entretanto, o Ca do complexo de troca apresenta tendência de incremento com a profundidade nos perfis P3 e P4. Os teores de Magnésio (Mg) nos solos estudados geralmente estão abaixo dos de $\mathrm{Ca}$, entretanto, apresentam comportamento semelhante nos perfis.

O complexo de troca possui alta proporção de $\mathrm{H}+\mathrm{Al}$, fazendo com que a percentagem de saturação de bases (V\%) seja baixo. Apesar da saturação por alumínio (M\%) ser maior que $50 \%$ em alguns horizontes dos perfis estudados, estes solos não possuem caráter alumínico devido ao baixo teor de alumínio extraível. Entretanto tem caráter distrófico por apresentarem valores $\mathrm{V}$ inferiores a $50 \%$.

A capacidade de troca de cátions $(\mathrm{T})$ desses solos é baixa e, devido a contribuição da matéria orgânica, os valores de $\mathrm{T}$ se encontram nos horizontes superficiais. 
Tabela 2 - Análise química dos solos da Topossequência Timburi.

\begin{tabular}{|c|c|c|c|c|c|c|c|c|c|c|c|c|c|c|c|}
\hline & & & & & & & & & & & & & & & \\
\hline & & $\mathrm{pH}$ & & M.O & $\mathbf{P}$ & $\mathrm{Na}$ & $\mathrm{K}$ & $\mathrm{Ca}$ & $\mathrm{Mg}$ & Al & $\mathrm{H}+\mathrm{Al}$ & SB & $\bar{T}$ & $\bar{V}$ & $\overline{\mathbf{M}}$ \\
\hline $\mathrm{Hz}$ & $\mathrm{H} 2 \mathrm{O}$ & $\mathrm{KCL}$ & $\mathrm{CaCl} 2$ & $\underset{\mathrm{kg}-1}{\mathrm{~g}}$ & $\mathrm{mg} \mathrm{kg} \mathrm{-1}$ & & & & $\begin{array}{c}\text { Mmolc } \\
\mathrm{kg}-1\end{array}$ & & & & & $(\%)$ & $(\%)$ \\
\hline $\mathrm{P} 1 \mathrm{~B} / \mathrm{A}$ & 4,6 & 3,6 & 3,8 & 17 & 4 & - & 1,9 & 10 & 2 & 11 & 61 & 13,9 & 74,9 & 19 & 44 \\
\hline P1B1 & 4,4 & 3,9 & 3,9 & 12 & 2 & - & 0,6 & 6 & 1 & 8 & 42 & 7,6 & 49,6 & 15 & 51 \\
\hline P1B2 & 4,7 & 4,0 & 4,0 & 10 & 1 & - & 0,9 & 4 & 1 & 4 & 34 & 5,9 & 39,9 & 15 & 40 \\
\hline P1CR & 4,7 & 4,0 & 4,0 & 12 & 2 & - & 2,4 & 6 & $T$ & 6 & 36 & 9,4 & 45,4 & 21 & 39 \\
\hline P1.4 & 5,2 & 3,7 & 3,9 & 3 & 4 & - & $\overline{5,0}$ & 10 & 10 & 47 & 63 & 25,0 & 88,0 & 28 & 65 \\
\hline P1.3 & 5,2 & 3,5 & 3,9 & 3 & 62 & - & 5,8 & 23 & 15 & 56 & 78 & 43,8 & 121,8 & 36 & 56 \\
\hline P1.2 & 4,9 & 3,7 & 4,0 & 5 & 53 & - & 6,0 & 20 & 13 & 8 & 73 & 39,0 & 112,0 & 35 & 17 \\
\hline P1.1 & 5,7 & 4,3 & 4,9 & 8 & 165 & - & 9,0 & 65 & 17 & 2 & 21 & 91,0 & 112,0 & 81 & 2 \\
\hline P2A/B & 4,5 & 3,7 & 3,9 & 12 & 3 & - & 2,6 & 1 & 1 & 9 & 53 & 4,6 & 57,6 & 8 & 66 \\
\hline P2B1 & 4,7 & 4,1 & $\overline{4,0}$ & 3 & 4 & - & 2,0 & 1 & 1 & 2 & 31 & 4,0 & 35,0 & 11 & 33 \\
\hline P2B2 & 4,1 & 4,0 & 3,9 & 3 & 2 & - & 0,7 & 1 & 1 & 5 & 32 & 2,7 & 34,7 & 8 & 65 \\
\hline P2BC & 4,8 & 4,2 & 4,0 & 5 & 2 & - & 0,7 & 3 & 3 & 3 & 25 & 6,7 & 31,7 & 21 & 31 \\
\hline P2C & 4,7 & 3,8 & 4,0 & 3 & 4 & - & 1,1 & 3 & 1 & 14 & 35 & 5,1 & 40,1 & 13 & 73 \\
\hline P2.5 & 4,7 & 3,8 & 3,7 & 5 & 2 & - & 0,9 & 2 & 1 & 34 & 50 & 3,9 & 53,9 & 7 & 90 \\
\hline P2.4 & 4,7 & 3,6 & 3,9 & 3 & 2 & - & 1,6 & 4 & 4 & 68 & 81 & 9,6 & 90,6 & 11 & 88 \\
\hline P2.3 & 4,7 & 3,6 & 3,8 & 3 & 8 & - & 3,8 & 9 & 4 & 53 & 64 & 16,8 & 80,8 & 21 & 76 \\
\hline$\overline{P 3 A}$ & 4,5 & 3,8 & 4,0 & 12 & 3 & - & 3,2 & 1 & 1 & 6 & 41 & 5,2 & 46,2 & 11 & 54 \\
\hline $\mathbf{P 3 B} / \mathbf{A}$ & 4,3 & 4,0 & 3,9 & 12 & 2 & - & 1,9 & 1 & 1 & 3 & 30 & 3,9 & 33,9 & 12 & 43 \\
\hline
\end{tabular}


Continuação da tabela 2 - Análise química dos solos da Topossequência Timburi.

\begin{tabular}{|c|c|c|c|c|c|c|c|c|c|c|c|c|c|c|c|}
\hline P3B1 & 4,6 & 4,1 & 4,1 & 5 & 2 & - & 1,3 & 2 & 1 & 3 & 29 & 4,3 & 33,3 & 13 & 41 \\
\hline P3B2 & 4,9 & 4,3 & 4,1 & 3 & 4 & - & 0,8 & 3 & 1 & 2 & 23 & 4,8 & 27,8 & 17 & 29 \\
\hline P3C & 4,7 & 3,8 & 3,9 & 3 & 1 & - & 0,5 & 3 & 1 & 15 & 33 & 4,5 & 37,5 & 12 & 77 \\
\hline P3.5 & 4,8 & 4,0 & 3,8 & 3 & 1 & - & 0,6 & 3 & 1 & 18 & 33 & 4,6 & 37,6 & 12 & 80 \\
\hline$\overline{\text { P3.4 }}$ & 4,9 & 3,5 & 3,9 & 3 & 10 & - & 3,3 & 5 & 15 & 123 & 55 & 23,3 & 78,3 & 30 & 84 \\
\hline P3.1 & 5,3 & 4,2 & 4,6 & 3 & 110 & - & 3,7 & 30 & 7 & 1 & 28 & 40,7 & 68,7 & 59 & 2 \\
\hline$\overline{\mathbf{P} 4 \mathbf{A} / \mathrm{B}}$ & 4,0 & 3,8 & 4,0 & 12 & 2 & - & 0,4 & 2 & 1 & 6 & 34 & 3,4 & 37,4 & 9 & 64 \\
\hline P4B1 & 4,5 & 4,1 & 4,1 & 8 & 2 & - & 0,4 & 4 & 1 & 2 & 22 & 5,4 & 27,4 & 20 & 27 \\
\hline$\overline{\text { P4B2 }}$ & 4,3 & 4,2 & 4,0 & 5 & 2 & - & 0,9 & 6 & 4 & 1 & 22 & 10,9 & 32,9 & 33 & 8 \\
\hline $\mathbf{P} 4.7$ & 4,3 & 3,9 & 3,8 & 3 & 2 & - & 0,1 & 2 & 1 & 18 & 35 & 3,1 & 38,1 & 8 & 85 \\
\hline P4.6 & 4,8 & 3,6 & 3,6 & 3 & 4 & - & 0,4 & 2 & 1 & 30 & 47 & 3,4 & \begin{tabular}{|l|}
50,4 \\
\end{tabular} & 7 & 90 \\
\hline $\mathbf{P 4 . 5}$ & 4,7 & 3,9 & 3,8 & 3 & $T$ & - & 0,1 & 2 & 1 & 14 & 31 & 3,1 & 34,1 & 9 & 82 \\
\hline P5A & 4,5 & 3,8 & 3,8 & 21 & 4 & - & 0,8 & 15 & 2 & 6 & 49 & 17,8 & \begin{tabular}{|l|}
66,8 \\
\end{tabular} & 27 & 25 \\
\hline $\mathrm{P5A} / \mathrm{B}$ & 4,6 & 4,1 & 4,0 & 12 & 2 & - & 0,3 & 4 & 1 & 3 & 36 & 5,3 & 41,3 & 13 & $\overline{36}$ \\
\hline P5B1 & 4,2 & 4,0 & 3,9 & 5 & 2 & - & 0,2 & 3 & 1 & 2 & 33 & 4,2 & 37,2 & 11 & 32 \\
\hline P5B2 & 4,6 & 4,3 & 4,1 & 5 & 6 & - & 0,3 & 2 & 1 & 2 & 25 & 3,3 & 28,3 & 12 & 38 \\
\hline P5C & 5,1 & 4,0 & 4,0 & 3 & 4 & - & 0,4 & 2 & 1 & 6 & 28 & 3,4 & 31,4 & 11 & 64 \\
\hline P5.4 & 4,7 & 3,6 & 3,7 & 3 & 12 & - & 1,1 & 7 & 3 & 75 & 91 & 11,1 & 102,1 & 11 & 87 \\
\hline P5.3 & 7,8 & 6,1 & 5,8 & 3 & 70 & - & 3,3 & 113 & 13 & 1 & 9 & 129,3 & 138,3 & 93 & 1 \\
\hline P5.2 & 5,5 & 3,7 & 4,1 & 5 & 173 & - & 4,9 & 53 & 13 & 11 & 146 & 70,9 & 216,9 & 33 & 13 \\
\hline P5.1 & 8,4 & 6,7 & 6,3 & 3 & 138 & - & 4,1 & 108 & 32 & 1 & 5 & 144,1 & 149,1 & 97 & 1 \\
\hline
\end{tabular}

Obs: (-) elemento não analisado ou valor "zero" no resultado.

$1.2 ; 1.3 ; 1.4 ; 2.3 ; 2.4 \ldots . .5 .4$ - correspondem as fácies de alteração da rocha derivada do riodacito.

$1.1 ; 3.1$ e 5.1 - correspondem a rocha sã (riodacito) 


\section{Ataque sulfúrico}

Comparando-se os conteúdos de silício (Si) e alumínio (Al) na Tabela 3, observa-se que os menores valores estão nos horizontes superficiais.

Em relação ao $\mathrm{Al}$, para o perfil $\mathrm{P} 1$ e $\mathrm{P} 4$, há uma diminuição do seu conteúdo nos horizontes superficiais à medida que caminha em profundidade, ao contrário dos perfis P2, P3 e P5 onde há um aumentos nos horizontes em direção a superfície. Quanto aos horizontes de alteração estes apresentam valores de baixos a médios de $\mathrm{Al}(0,71 \%$ a $26,16 \%)$.

Os valores de $\mathrm{Ki}$ e $\mathrm{Kr}$ são baixos indicando solos bastante intemperizados (solos evoluídos) se enquadrando no parâmetro exigido na classe dos latossolos (Ki $<2.2$ ), segundo Embrapa 1999. Em profundidade a quantidade de $\mathrm{Si}, \mathrm{Al}$ e $\mathrm{Fe}$ foi decrescente. Comparando-se o elemento Ferro (Fe) e Titânio (Ti), observa-se que os menores valores encontram-se nas rochas.

Os teores de Ti são baixos em todos os perfis, variando de 0,53 a 2,19\%. Essa variação nos teores podem estar ligadas ao intemperismo de minerais como a ilmenita por exemplo.

\subsection{2 - Análise por Fluorescência de raios-X}

Os resultados químicos obtidos na Tabela 4, mostraram para a rocha sã grande semelhança com os dados apresentados por outros autores, com os teores de $\mathrm{SiO}_{2}$ ao redor de $65 \%, \mathrm{Al}_{2} \mathrm{O}_{3} 15 \%$ e outros de menor quantidade também próximos.

Entretanto, os dados da análise por fluorescência de raios- $X$ das fases de alteração mostraram que, à medida que esta avança, ocorre um enriquecimento relativo do $\mathrm{Al}_{2} \mathrm{O}_{3}$ em detrimento do $\mathrm{SiO}_{2}$ e dos outros elementos. Esta mesma relação foi encontrada por Clemente (1988), em seu trabalho sobre alteração de rochas.

De acordo com Raposo (1987), os piroxênios encontrados nos riodacitos, apresentam uma quantidade alta de $\mathrm{TiO}_{2}$, isto provavelmente ocorre devido a cristalização concomitante de fenocristais de magnetita, que dificulta a entrada de $\mathrm{Fe}^{3+}$ nos piroxênios e ao balanceamento de cargas, que é feito com conteúdos relativamente altos de $\mathrm{TiO}_{2}$ nos piroxênios. 
Tabela 3 - Análise ataque sulfúrico da Topossequência Timburi.

\begin{tabular}{|c|c|c|c|c|c|c|c|}
\hline & $\mathbf{S i O}_{2}$ & $\mathbf{A l}_{2} \mathbf{O}_{3}$ & $\mathbf{F e}_{2} \mathbf{O}_{3}$ & $\mathbf{T i O}_{2}$ & $\mathbf{M n O}$ & \multirow{2}{*}{$\mathbf{~} \mathbf{~}$} & $\mathbf{K r}$ \\
\cline { 2 - 6 } Horizonte & & & $\mathbf{( \% )}$ & & & & \\
\hline P1 B\A & 26,10 & 22,84 & 13,76 & 1,85 & 0,06 & 1,94 & 1,40 \\
\hline P1 B1 & 27,1 & 24,83 & 13,01 & 1,88 & 0,05 & 1,86 & 1,39 \\
\hline P1 B2 & 27,40 & 25,54 & 13,75 & 1,90 & 0,05 & 1,82 & 1,36 \\
\hline P1 CR & 26,90 & 24,73 & 13,41 & 1,89 & 0,06 & 1,85 & 1,37 \\
\hline P1-4 & 21,80 & 15,86 & 8,61 & 1,17 & 0,06 & 2,34 & 1,73 \\
\hline P1-3 & 9,60 & 4,95 & 7,33 & 1,13 & 0,06 & 3,30 & 1,69 \\
\hline P1-2 & 9,90 & 4,84 & 8,15 & 1,19 & 0,07 & 3,48 & 1,67 \\
\hline P1-1 & 4,90 & 2,24 & 5,61 & 0,93 & 0,08 & 3,72 & 1,43 \\
\hline
\end{tabular}

\begin{tabular}{|c|c|c|c|c|c|c|c|}
\hline $\mathbf{P 2} \mathbf{A} \backslash \mathbf{B}$ & 28,50 & 24,83 & 13,59 & 1,96 & 0,07 & 1,95 & 1,45 \\
\hline $\mathbf{P 2} \mathbf{B 1}$ & 28,90 & 26,06 & 13,98 & 1,92 & 0,06 & 1,89 & 1,40 \\
\hline $\mathbf{P 2} \mathbf{B 2}$ & 27,50 & 25,85 & 13,62 & 1,86 & 0,06 & 1,81 & 1,35 \\
\hline $\mathbf{P 2} \mathbf{B C}$ & 32,00 & 26,16 & 13,48 & 1,85 & 0,06 & 2,08 & 1,56 \\
\hline $\mathbf{P 2} \mathbf{C}$ & 26,70 & 23,51 & 12,19 & 1,76 & 0,06 & 1,93 & 1,45 \\
\hline $\mathbf{P 2 . 5}$ & 28,90 & 24,73 & 9,88 & 1,57 & 0,06 & 1,99 & 1,58 \\
\hline $\mathbf{P 2 . 4}$ & 23,30 & 17,39 & 10,47 & 1,33 & 0,07 & 2,28 & 1,64 \\
\hline $\mathbf{P 2 . 3}$ & 27,20 & 18,15 & 9,22 & 1,47 & 0,09 & 2,55 & 1,92 \\
\hline
\end{tabular}

\begin{tabular}{|c|c|c|c|c|c|c|c|}
\hline P3A & 28,20 & 24,52 & 12,73 & 1,76 & 0,06 & 1,96 & 1,47 \\
\hline P3BA & 27,30 & 24,43 & 12,48 & 1,74 & 0,06 & 1,90 & 1,43 \\
\hline P3B1 & 28,60 & 25,24 & 13,16 & 1,79 & 0,06 & 1,93 & 1,44 \\
\hline P3B2 & 30,80 & 24,83 & 12,83 & 1,80 & 0,06 & 2,11 & 1,58 \\
\hline P3C & 29,00 & 22,03 & 11,87 & 1,67 & 0,07 & 2,24 & 1,66 \\
\hline P3.5 & 24,90 & 20,80 & 9,90 & 1,34 & 0,06 & 2,04 & 1,56 \\
\hline
\end{tabular}


Continuação da tabela 3 - Análise ataque sulfúrico da Topossequência Timburi.

\begin{tabular}{|c|c|c|c|c|c|c|c|}
\hline P3.4 & 25,50 & 16,16 & 8,58 & 1,26 & 0,09 & 2,68 & 2,00 \\
\hline P3.1 & 5,20 & 2,86 & 5,51 & 1,15 & 0,05 & 3,09 & 1,38 \\
\hline P4 A $\backslash B$ & 29,40 & 25,09 & 13,26 & 1,76 & 0,06 & 1,99 & 1,49 \\
\hline P4 B2 & 30,90 & 24,88 & 13,15 & 1,79 & 0,06 & 2,11 & 1,58 \\
\hline P4 B1 & 28,20 & 25,70 & 13,40 & 1,83 & 0,06 & 1,87 & 1,40 \\
\hline $\mathbf{P 4 . 7}$ & 27,20 & 22,95 & 12,44 & 1,47 & 0,08 & 2,01 & 1,50 \\
\hline $\mathbf{P 4 . 6}$ & 24,60 & 19,38 & 10,19 & 1,32 & 0,08 & 2,16 & 1,61 \\
\hline P4.5 & 27,90 & 22,23 & 10,37 & 1,48 & 0,06 & 2,13 & 1,64 \\
\hline P5A & 25,90 & 23,76 & 12,58 & 2,19 & 0,06 & 1,85 & 1,38 \\
\hline P5 $A \backslash B$ & 25,20 & 25,39 & 13,44 & 1,98 & 0,05 & 1,69 & 1,26 \\
\hline P5 B1 & 26,80 & 25,49 & 13,87 & 2,09 & 0,06 & 1,79 & 1,33 \\
\hline P5 B2 & 25,50 & 26,10 & 13,73 & 2,00 & 0,05 & 1,66 & 1,24 \\
\hline P5 C & 25,40 & 23,45 & 13,05 & 1,62 & 0,05 & 1,84 & 1,36 \\
\hline P5.4 & 17,30 & 20,39 & 11,80 & 1,24 & 0,07 & 1,44 & 1,05 \\
\hline P5.3 & 10,20 & 5,60 & 7,11 & 0,79 & 0,05 & 3,10 & 1,71 \\
\hline P5.2 & 8,60 & 3,77 & 5,05 & 0,62 & 0,03 & 3,88 & 2,09 \\
\hline P5.1 & 4,10 & 0,71 & 4,65 & 0,53 & 0,05 & 9,82 & 1,89 \\
\hline
\end{tabular}

Obs:

$1.2 ; 1.3 ; 1.4 ; 2.3 ; 2.4 \ldots .5 .4$ - correspondem as fácies de alteração da rocha derivada do riodacito.

$1.1 ; 3.1$ e 5.1 - correspondem a rocha sã (riodacito). 


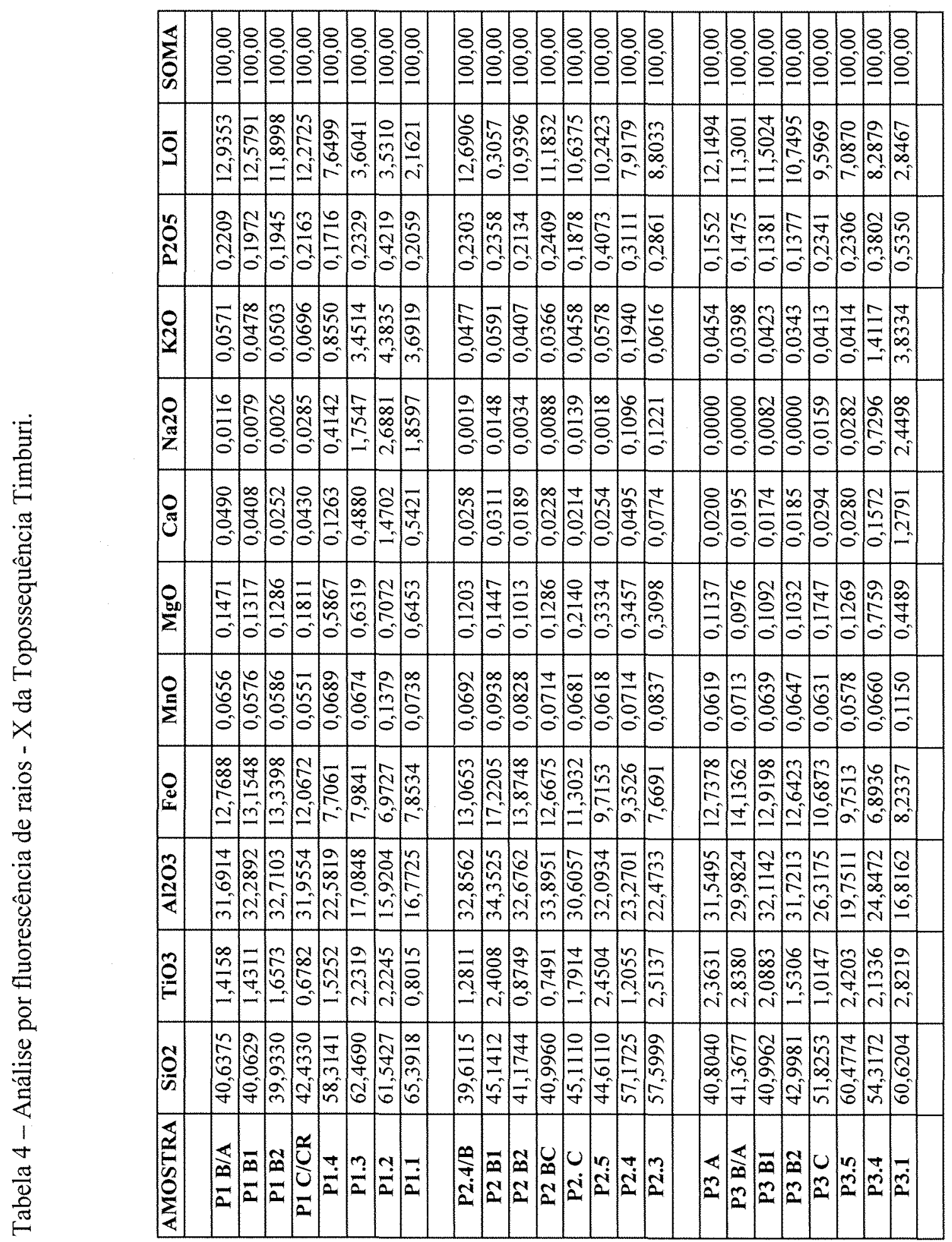




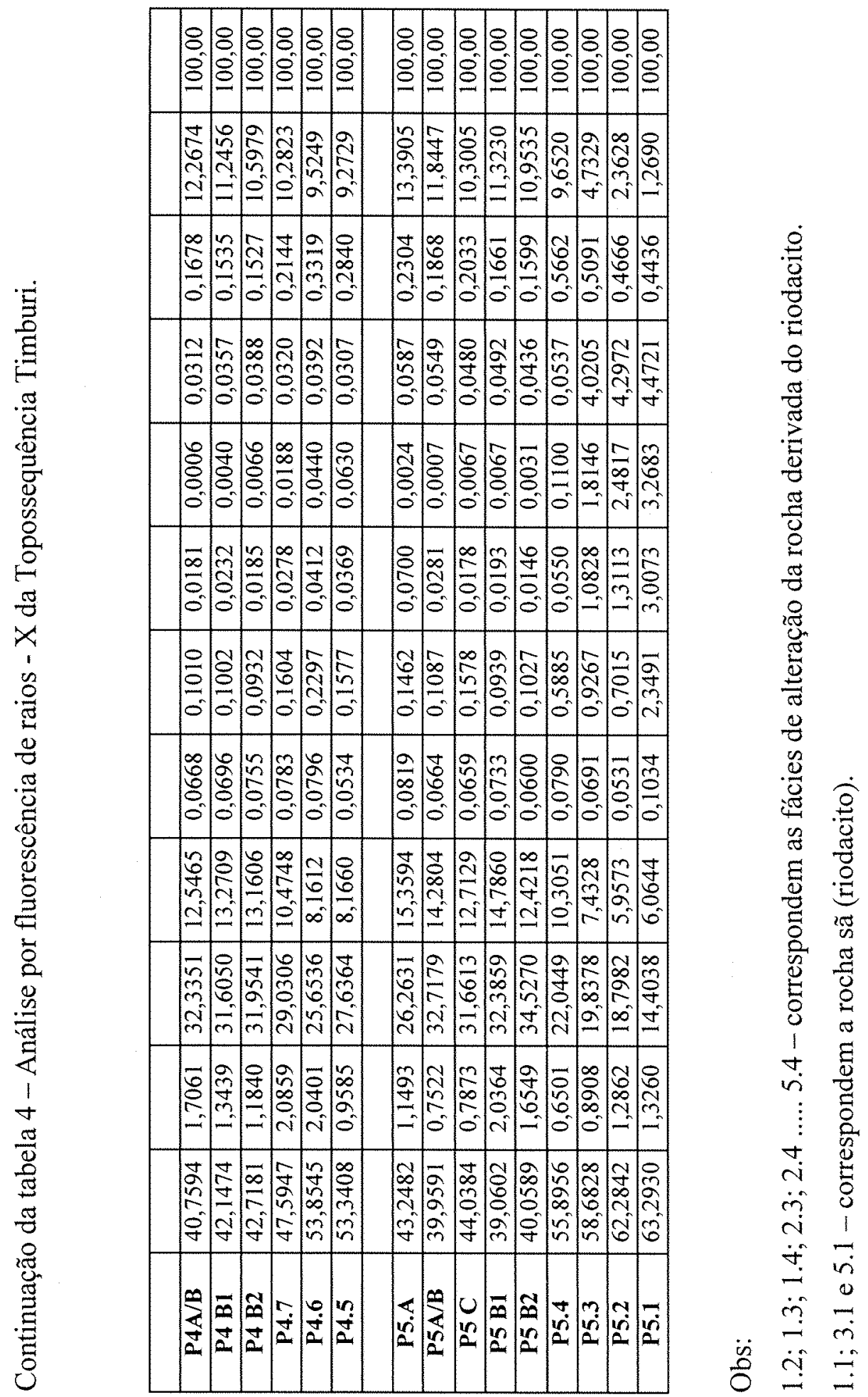




\subsection{Evidências mineralógicas}

\subsubsection{Análise por Microscopia óptica}

Os riodacitos estudados na região de Pirajú, são representados por macrofenocristais de plagioclásio (2\%), fenocristais de plagioclásio $(5 \%)$, piroxênios (3\%), opacos (ilmenita e Ti-magnetita $5 \%$, na forma de fenocristais e microfenocristais).

A matriz (80 - 85\%) dessa rocha é composta praticamente pelos mesmos minerais citados, além de feldspato alcalino (ortoclásio) e quartzo.

Os minerais presentes na matriz, apresentam textura de resfriamento rápido, onde, os plagioclásios são mal formados, os piroxênios mostram-se ocos e a magnetita de forma esqueletal.

Em algumas amostras ocorrem vesículas preenchidas por zeólitas (fotomicrografia 1 a e b).

A textura encontrada é classificada como fracamente porfirítica, pois, apresenta no máximo $5 \%$ de fenocristais.

Quanto ao grau de cristalinidade, a rocha caracteriza-se como holocristalina por conter quase que a totalidade de componentes cristalinos.

Os cristais de plagioclásio quando ocorrem na forma de fenocristais, são euhedrais à subhedrais, levemente zonados. Os macrofenocristais de plagioclásio são euhedrais, levemente zonados.

Os cristais de piroxênio são anhedrais (granulares) a subhedrais (prismáticos) e são representados principalmente por augita. De acordo com Nardy (1986) os piroxênios cálcicos (augita) são de cristalização precoce, ou seja, que ocorrem como fenocristais, são mais enriquecidos em Ca do que aqueles de cristalização tardia (os que ocorrem como microfenocristais ou na matriz), que por sua vez, são mais enriquecidos em ferro.

As zeólitas são silicatos de alumínio com sódio e cálcio (Dana, 1978). São comuns em rochas de origem vulcânica, onde preenchem vacúolos durante a fase hidrotermal no resfriamento das lavas. As zeólitas são instáveis no meio ácido (Ming \& Mumpton, 1989), o que explica a sua ausência nos horizontes mais superficiais do perfil de solo, bem como em classes de solo com feições de intemperismo mais avançado. 

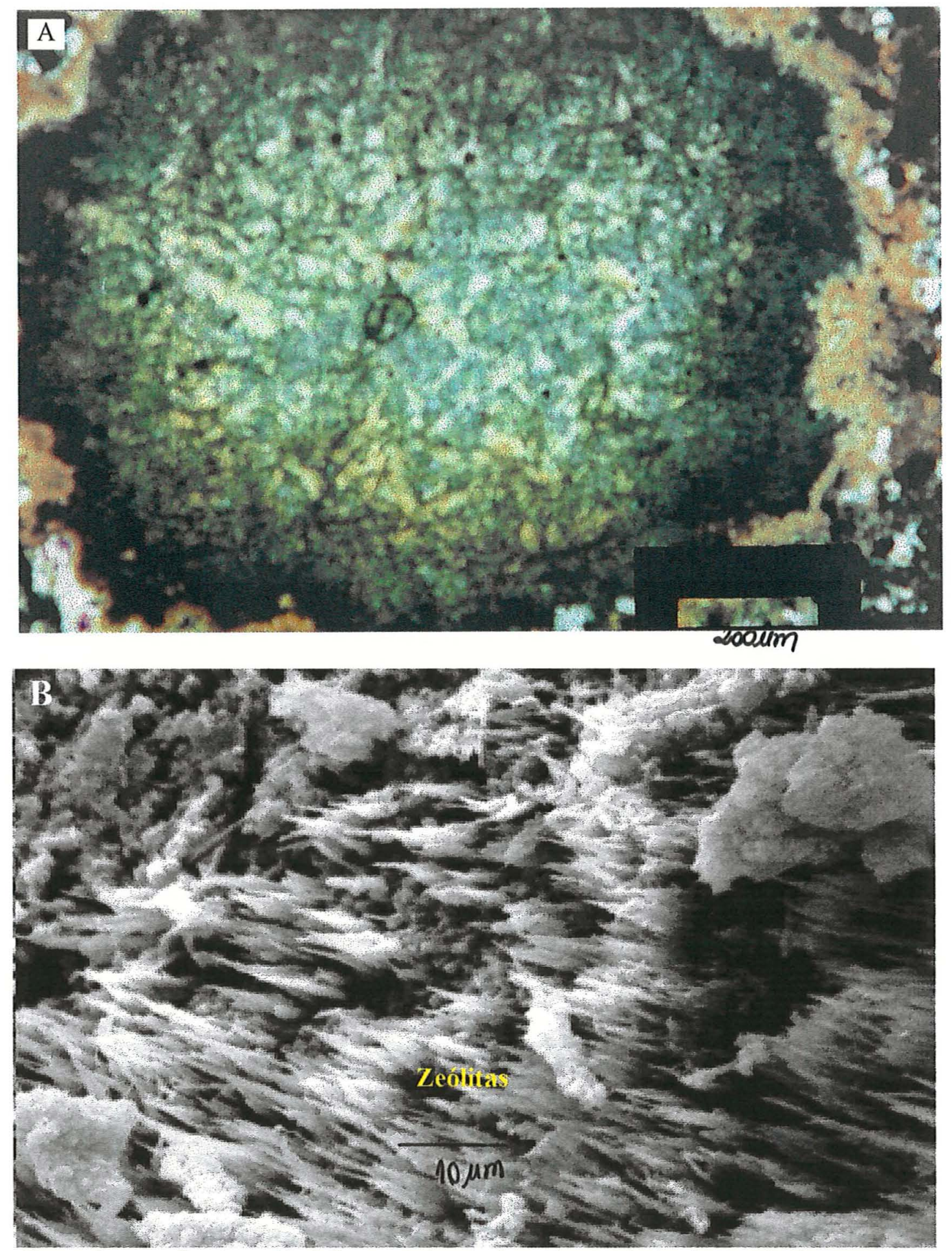

Fotomicrografia 1 - A) Microscópio óptico, luz polarizada e nicóis cruzados com aumento de x 2,5. Vesícula preenchida por zeólitas, de hábito acicular, em forma de cristais alongados e auréola de alteração por óxido-hidróxido de ferro; B) Microscópio Eletrônico de Varredura, apresentando maior detalhe das zeólitas. 
Os minerais opacos ocorrem como fenocristais e microfenocristais, subhedaris, com forma granular e esqueletal.

\subsubsection{Análises mineralógicas}

Nas figuras 11 a 15, encontram-se os difratogramas de raios-X da fração argila total para os horizontes selecionados de cada perfil. Constata-se que a mineralogia é bastante similar para os 5 perfis, sendo composta de caolinita (dominante), argilominerais com reflexão a 1,4 nm (vermiculita), gibbsita, esmectita, mica e plagioclásio (anortita).

Em todos os perfis analisados, há bastante semelhança das características mineralógicas, indicando a homogeneidade do material de origem.

Esse aspecto se coaduna com a descrição geral e morfológica, que não mostrou evidências de descontinuidade litológica nestes perfis.

Os reflexos da caolinita em todos os perfis são agudos e simétricos, sugerindo trata-se de argilominerais com alta cristalinidade a 0,$72 ; 0,36$ e $0,35 \mathrm{~nm}$, os quais são eliminados pelo aquecimento a $550^{\circ} \mathrm{C}$.

Não há variação no padrão da caolinita ao longo dos perfis, indicando ter sido formada "in situ", neste caso, produto de alteração de riodacitos da Formação Serra Geral.

Pequena quantidade de mica com picos a 1,$11 ; 0,51$ e $0,35 \mathrm{~nm}$ são detectados. A presença de uma pequena reflexão numa posição em torno de $1,4 \mathrm{~nm}$, que, praticamente, não se modifica no tratamento com glicol, é indicativa também da presença de argilominerais do tipo 2:1, provavelmente vermiculita (Douglas, 1989) e sua presença pode ser confirmada por seus picos intermediários a 0,49 e $0,43 \mathrm{~nm}$.

A formação de pico próximo a $1,4-1,8 \mathrm{~nm}$ pode indicar a presença de esmectita (Douglas, 1989) ou interestratificado desse mineral com micas (Sawhney, 1989).

A gibbsita mostra picos intensos em 0,48 e $0,43 \mathrm{~nm}$, sendo destruída pelo aquecimento a $350^{\circ} \mathrm{C}$. 

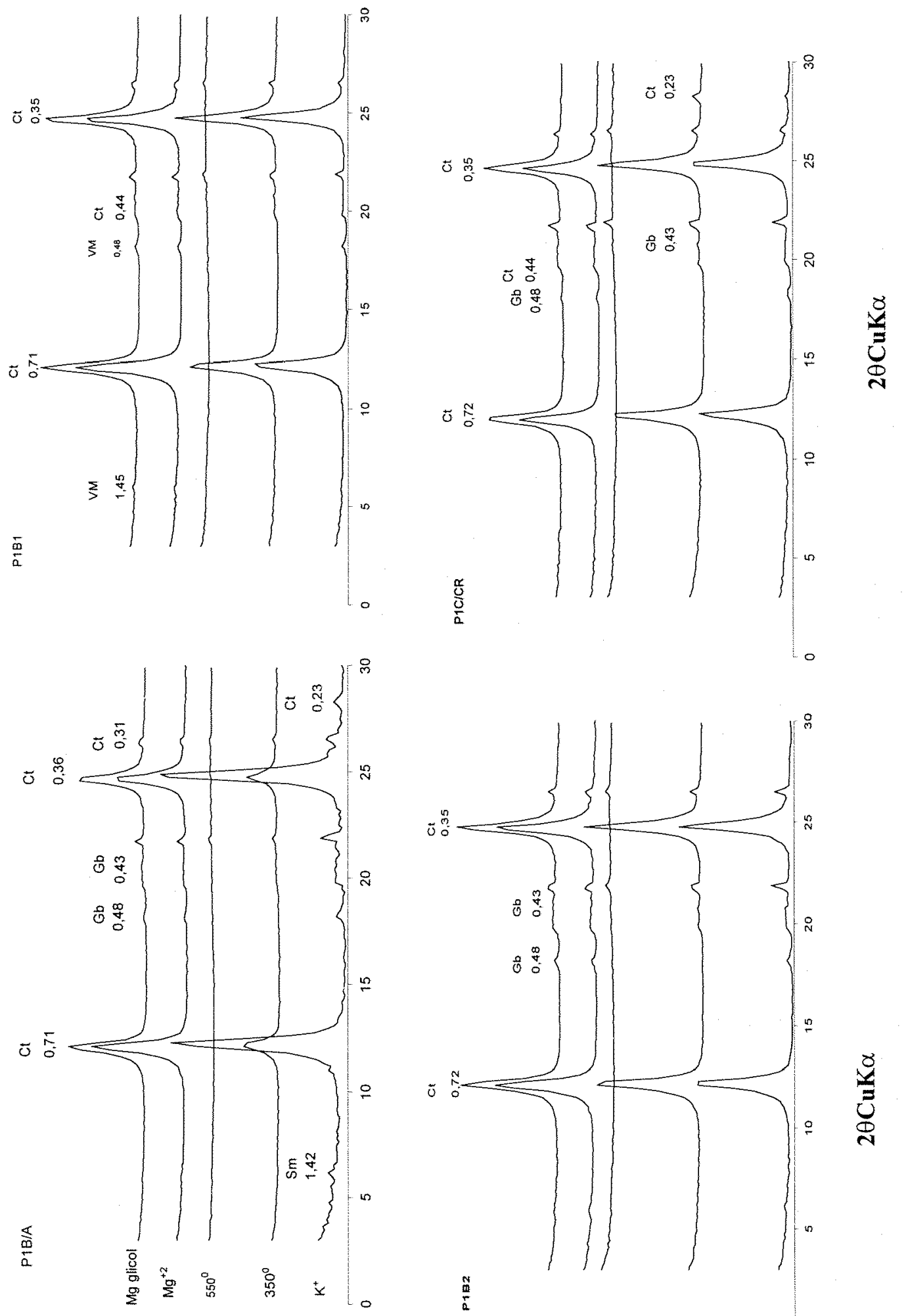

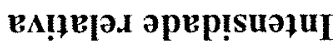

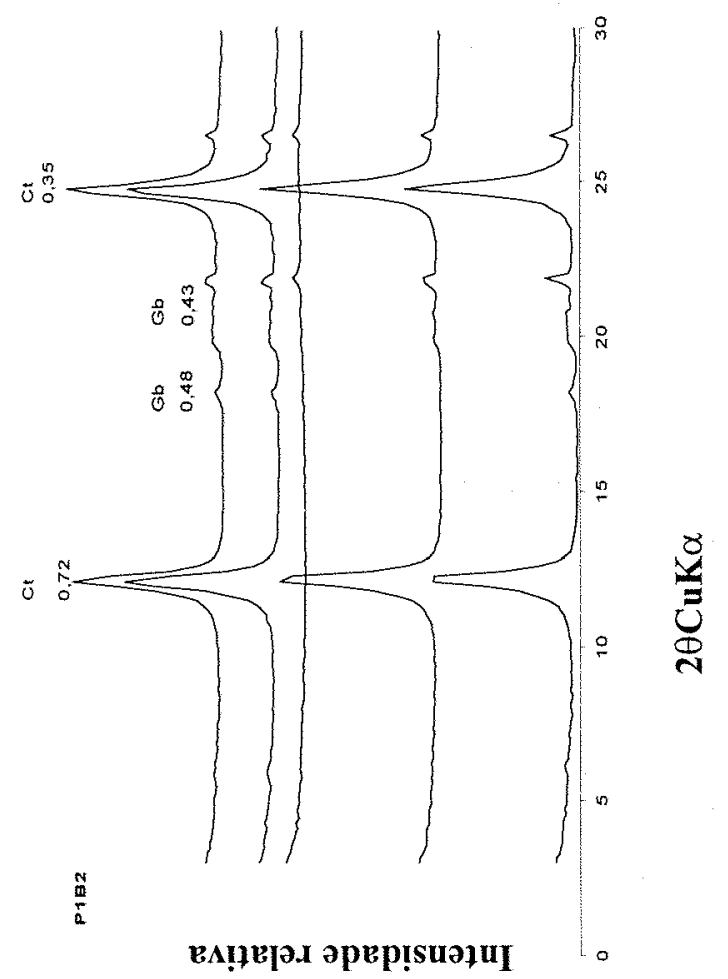

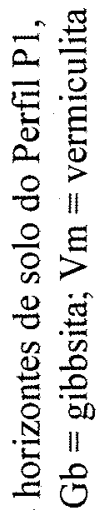

号.

胥

.

可

尤

if \&

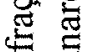

용

$\times$

क.

त्]

\&

密

总

50

윤

4 导

늘

$\overline{0} \|$

总 


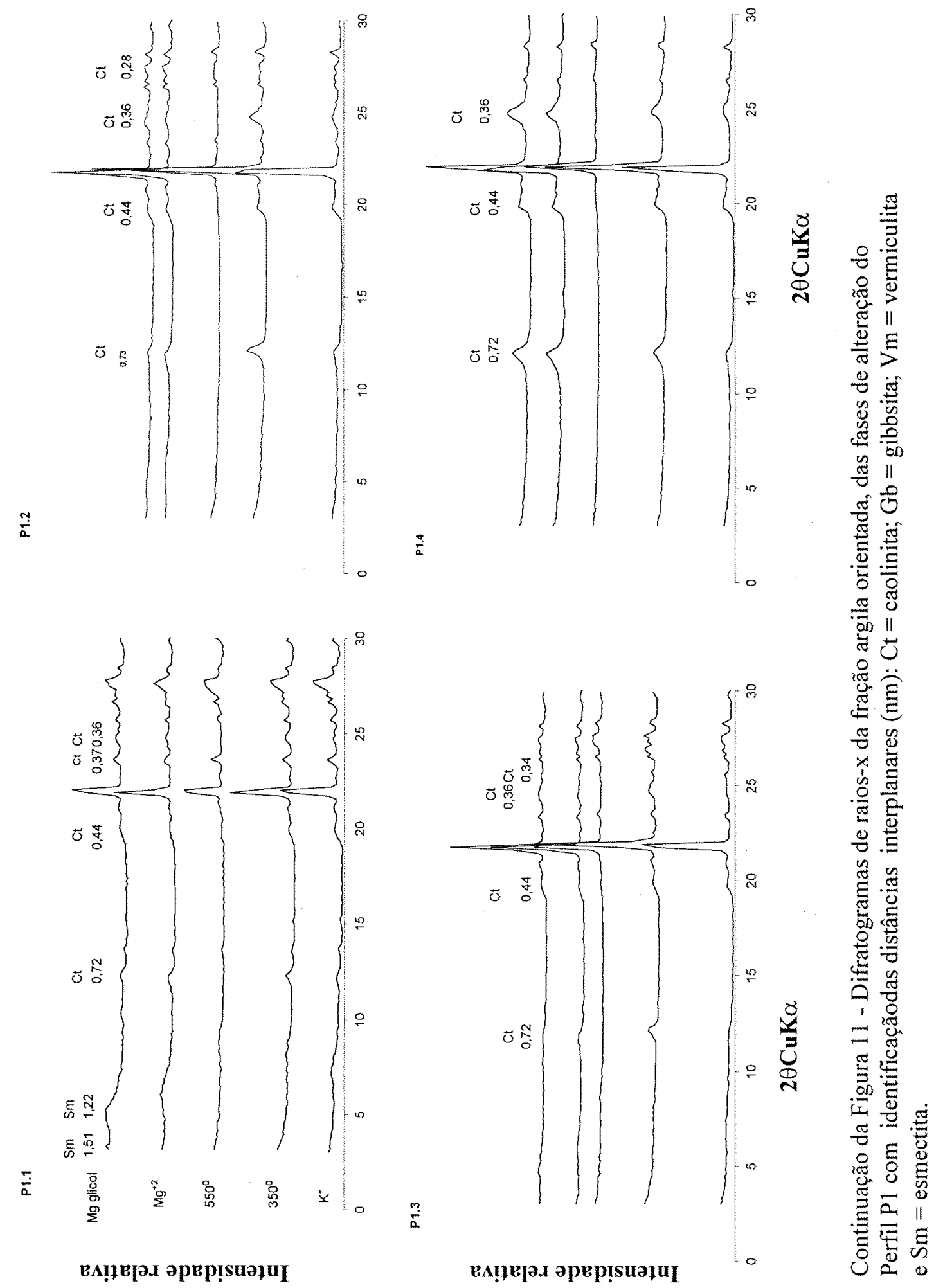




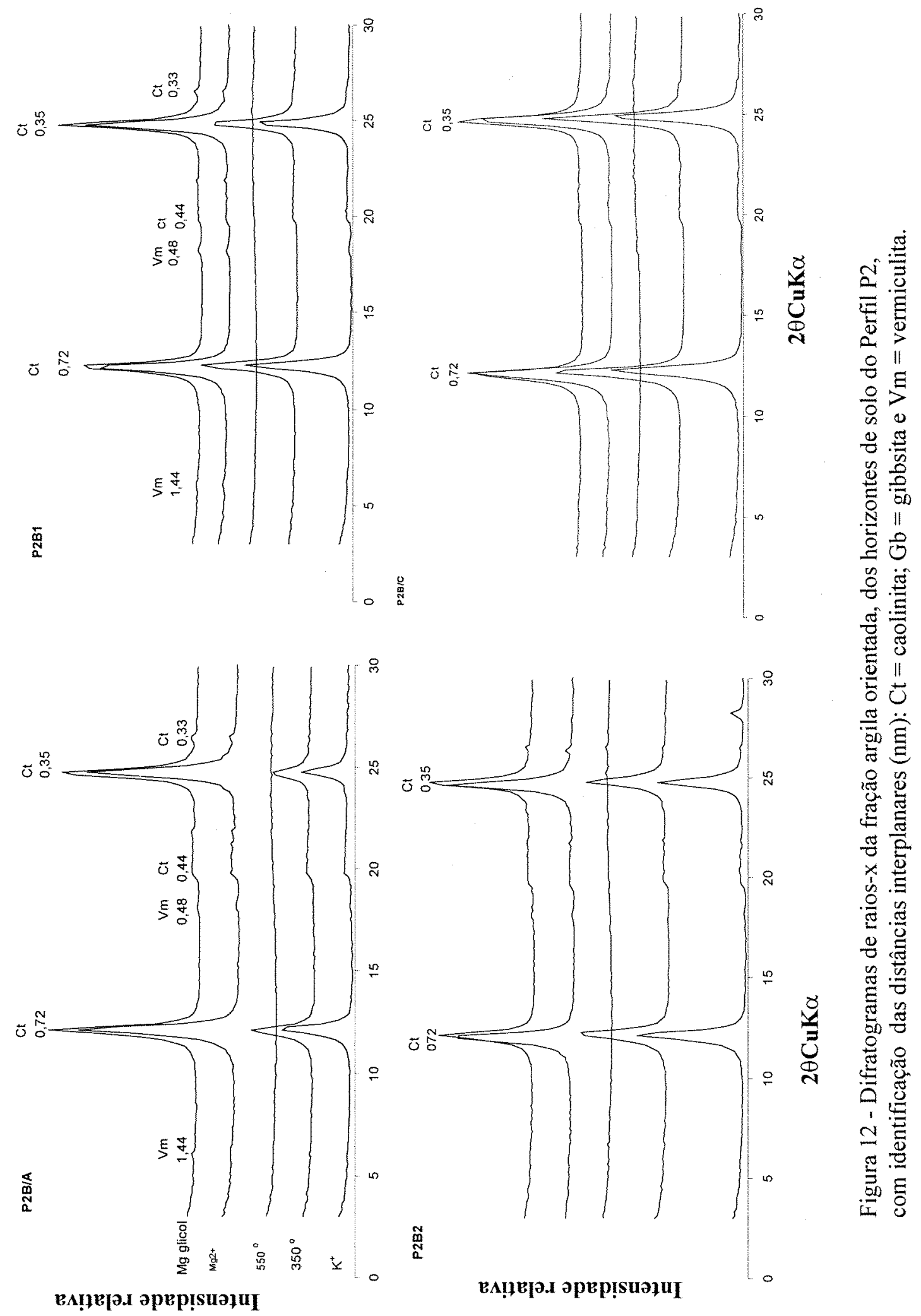




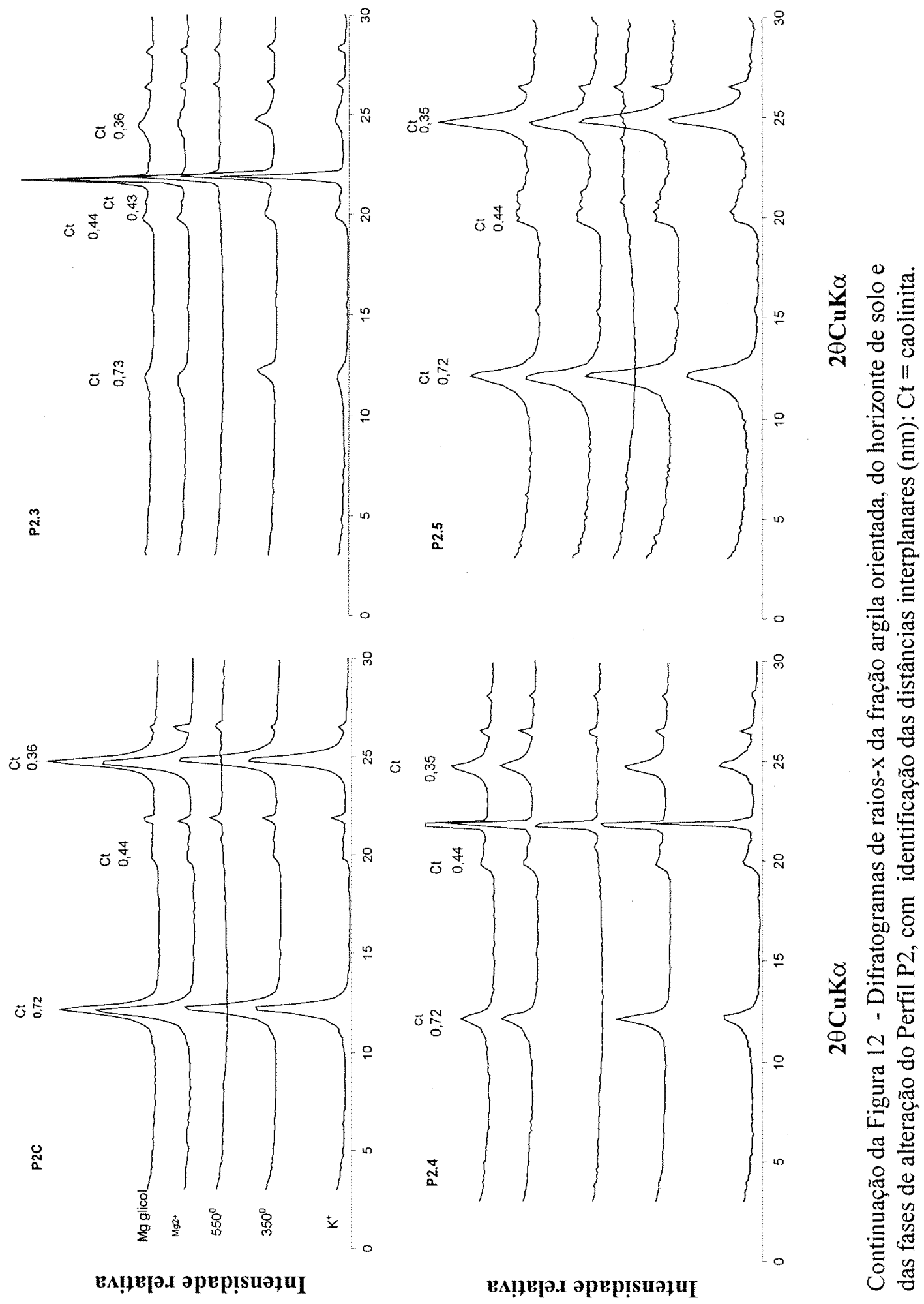



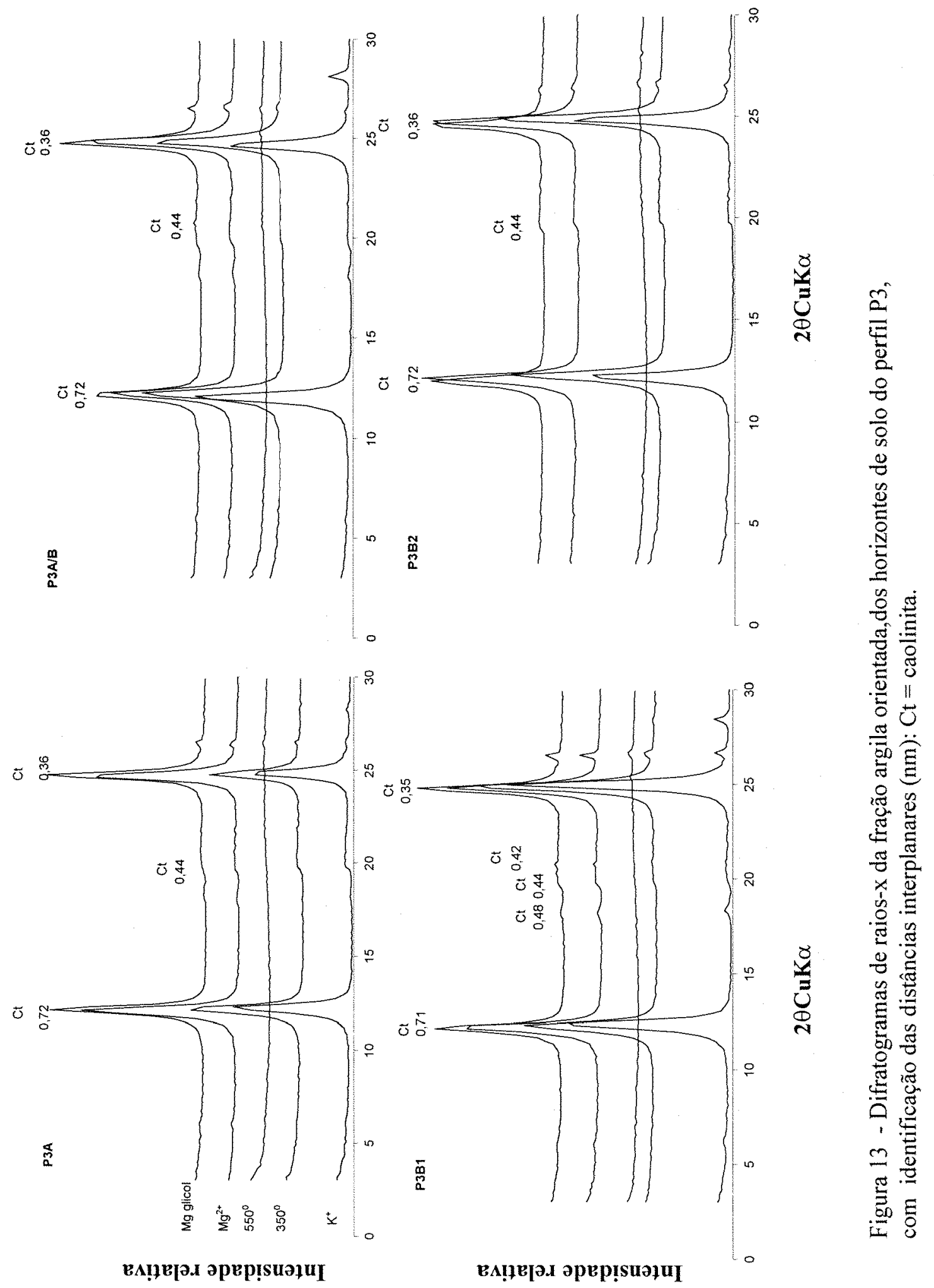


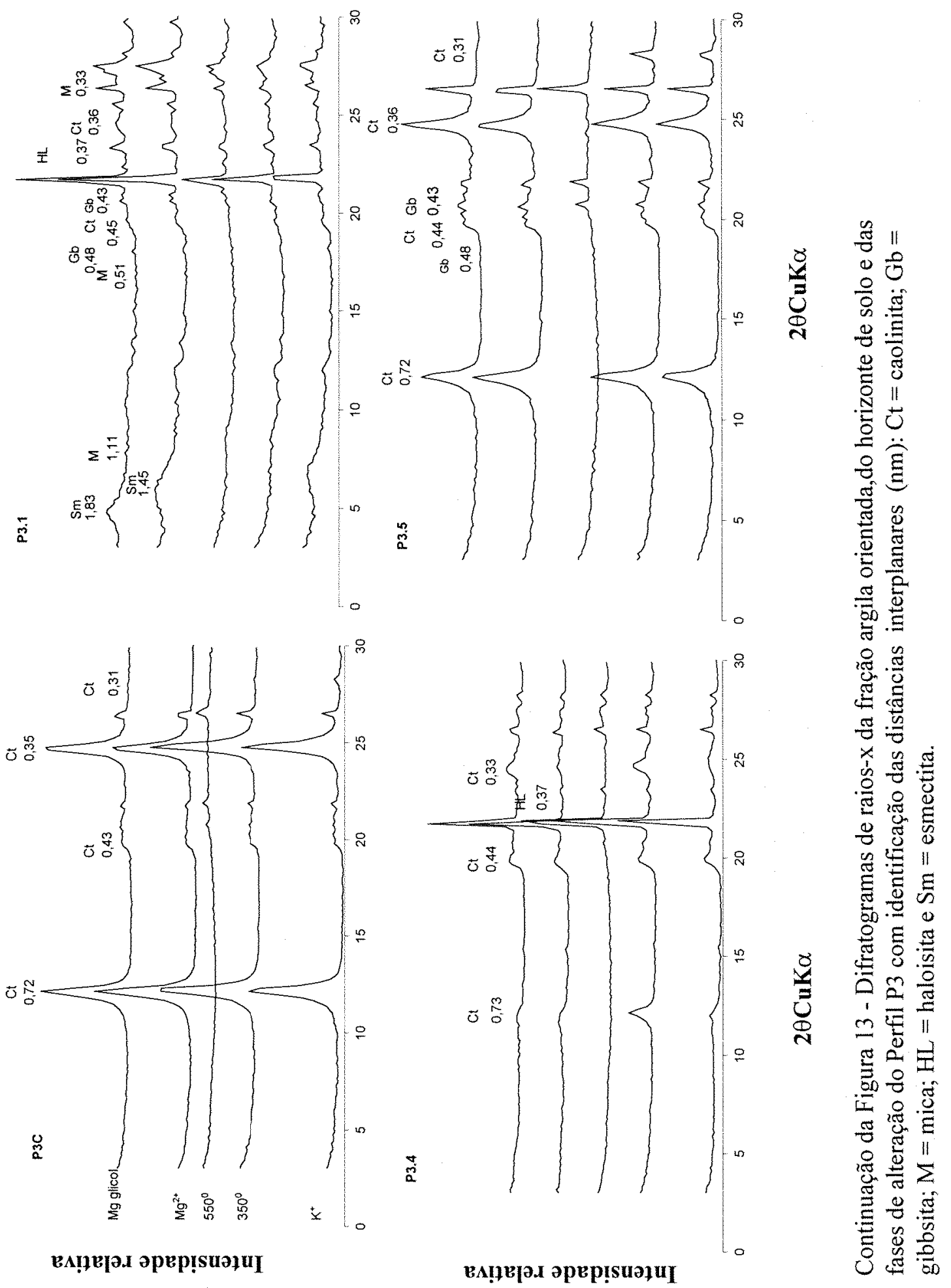




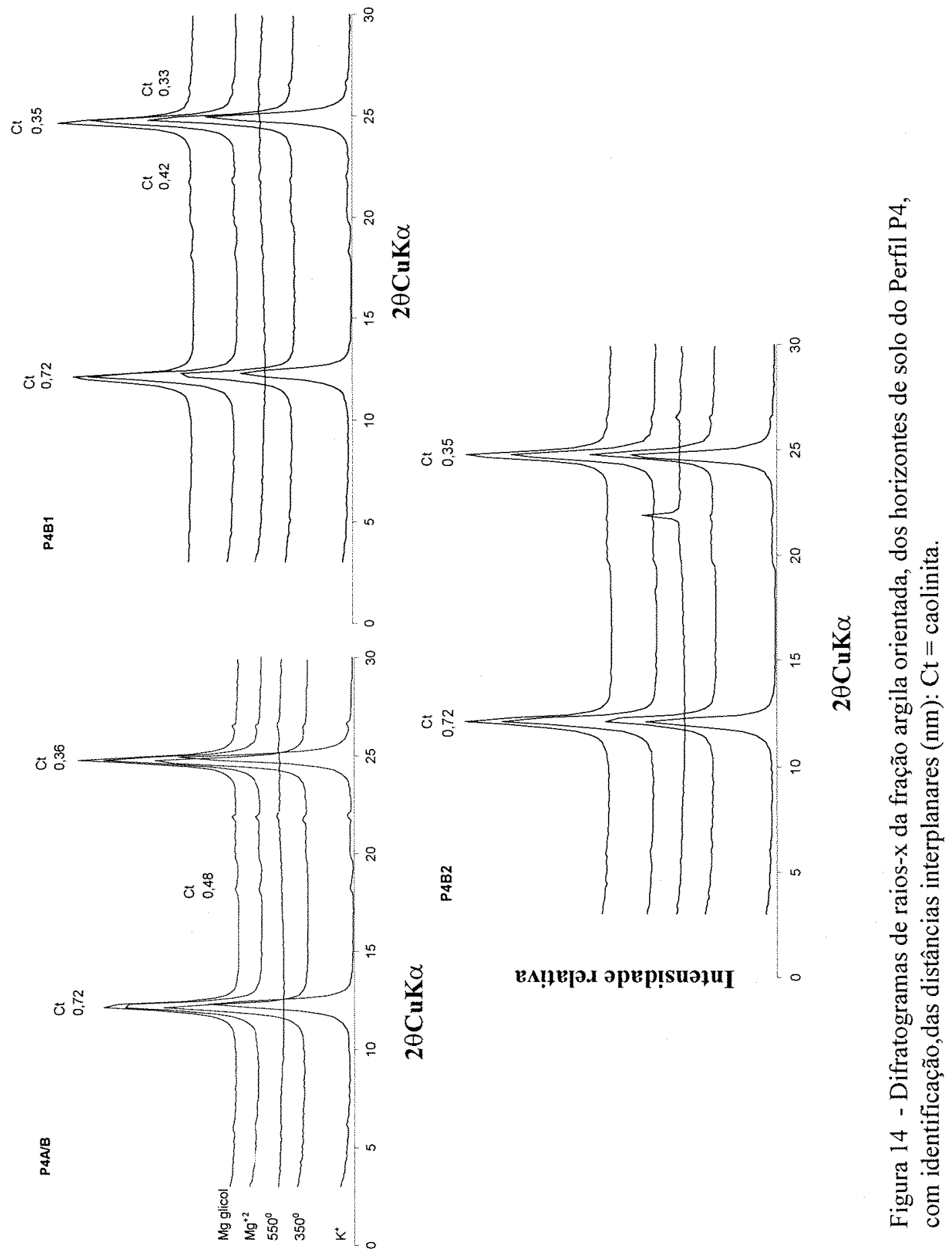

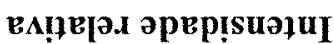




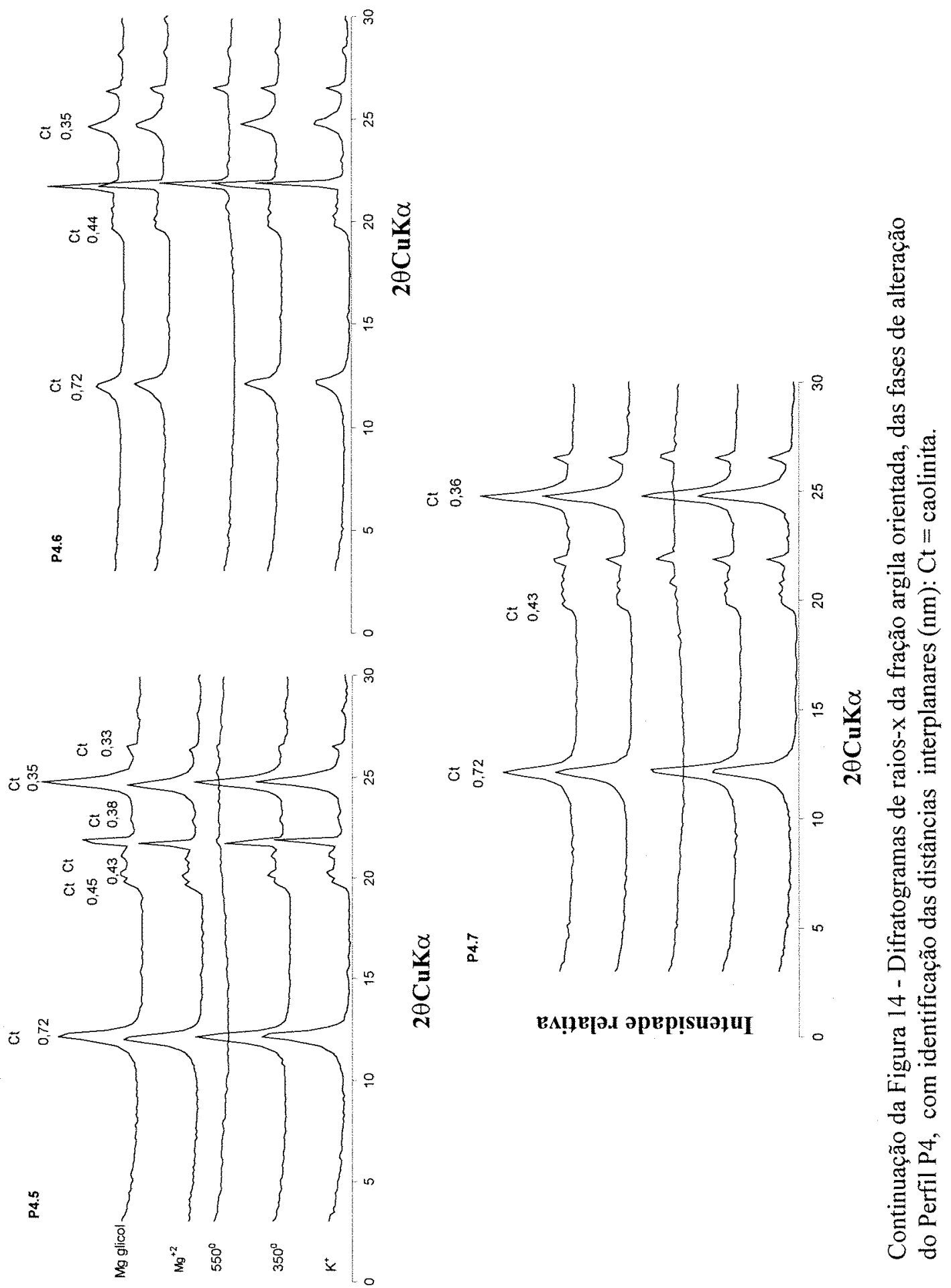

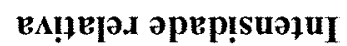




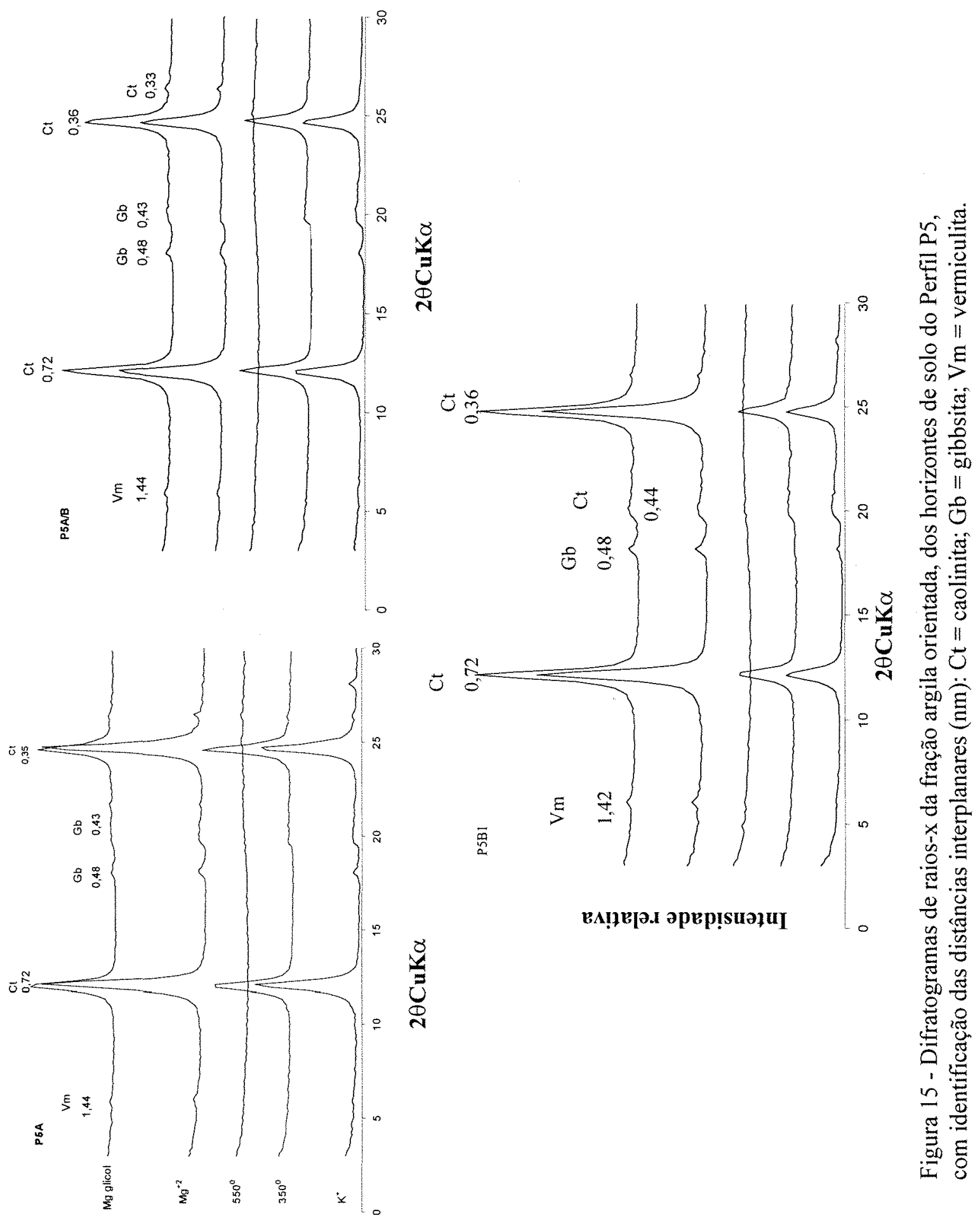

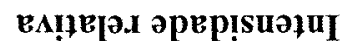



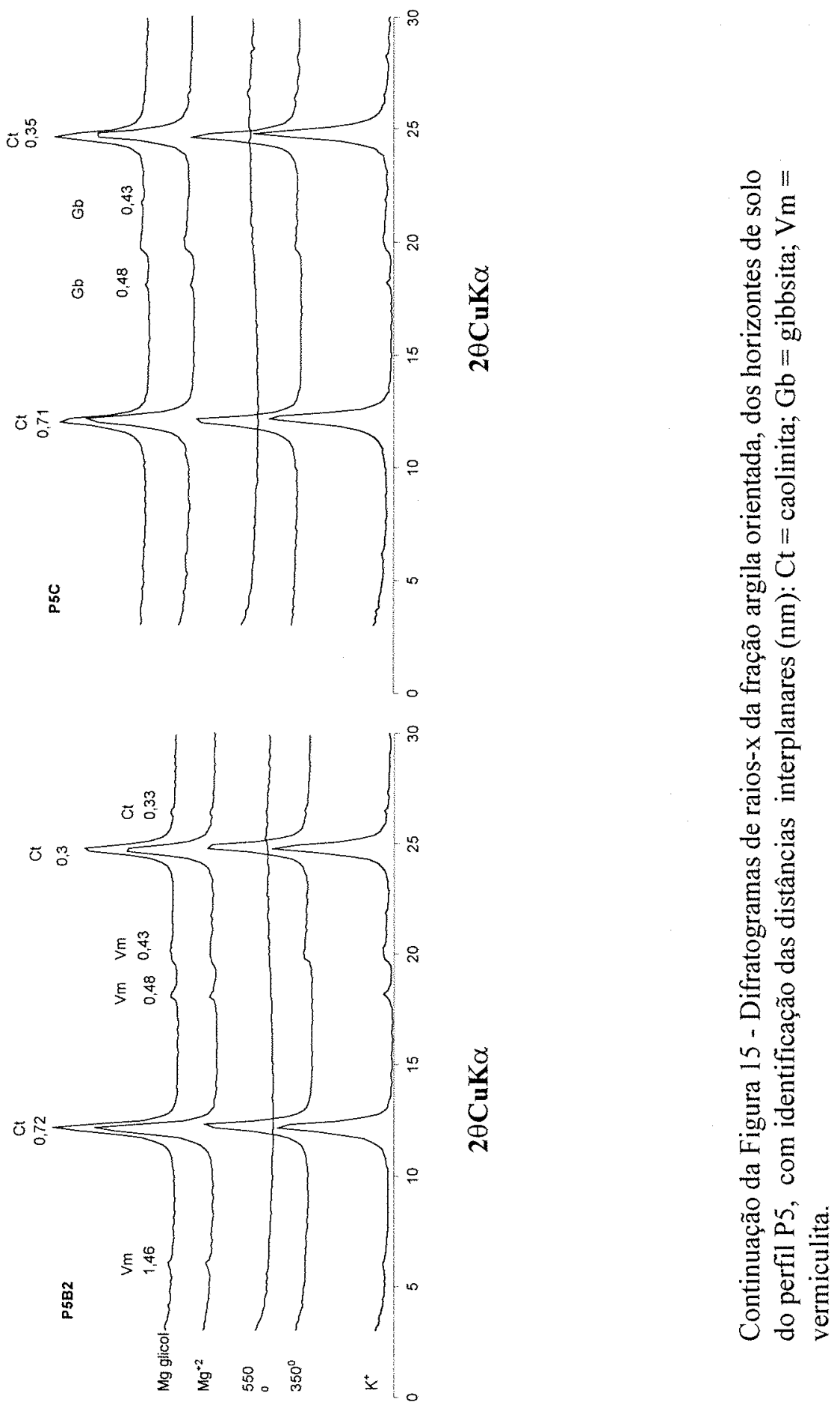

$\frac{8}{3}$

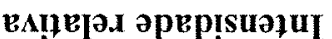




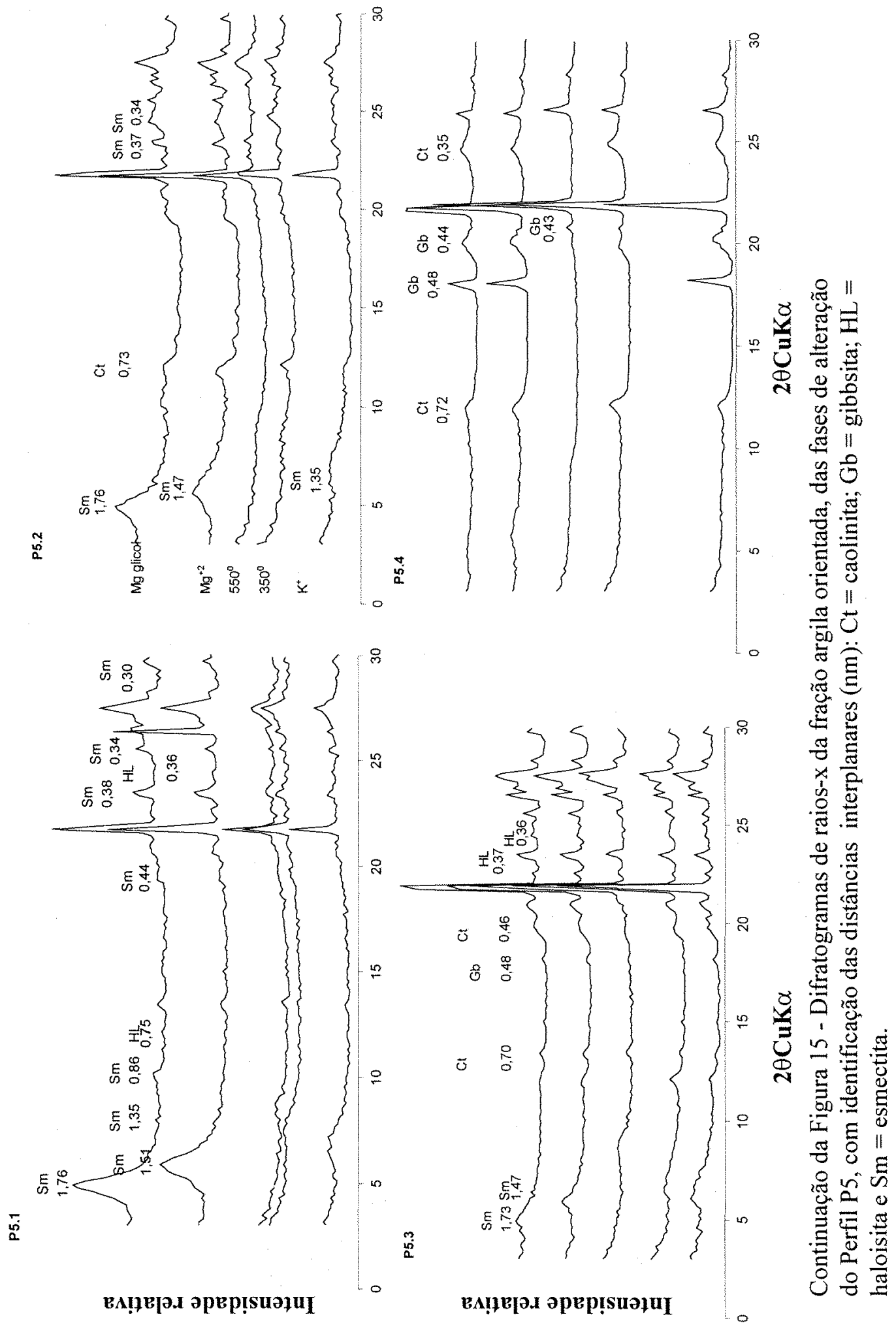


No perfil P 5.1 ocorre o aparecimento de haloisitas em 0,75 e $0,36 \mathrm{~nm}$. De acordo com Kampf (1995), tratam-se de haloisitas de baixa frequência, podendo ser decorrência de uma desidratação natural ocorrida no campo.

Dixon (1989) explica que a instabilidade das haloisitas, até em condições ambientes, torna-a como um constituinte incomum nos solos devido às condições de dessecação que são normalmente submetidas no seu ambiente natural.

Estudos realizados por Kretzschmar et al. (1996) sugerem que as haloisitas de hábito tabular possam ser produtos de alteração de biotitas e que estas haloisitas são argilominerais dominantes em saprolitos, mas o seu conteúdo diminui em direção a superfície do solo.

As haloisitas podem também ser produto da alteração de zeólitas. A alteração de zeólitas em esmectita é conhecida, enquanto que a formação de haloisitas não está citada na literatura (Ming \& Mumpton, 1989).

As figuras 16 a 20 mostram os difratogramas de raios- $X$ da fração silte.

Observa-se grande similaridade mineralógica entre eles, com dominância de quartzo, plagioclásio (anortita), feldspato (ortoclásio), piroxênio e pequenos picos de caolinita, o que, em parte, pode ser decorrente de uma separação inadequada da fração silte.

Os difratogramas apresentam picos intensos de quartzo com picos característicos em 0,42 e $0,33 \mathrm{~nm}$, e com picos intermediários em 0,$22 ; 0,18$ e $0,16 \mathrm{~nm}$, podendo ser um mineral herdado da rocha.

Os picos referentes ao plagioclásio $(0,40 ; 0,34$ e $0,32 \mathrm{~nm})$ e os feldspatos $(0,34 ; 0,29 ; 0,27$ e $0,25 \mathrm{~nm})$ não são muito intensos e alguns desses picos são coincidentes com a magnetita, também encontrada na rocha, destacando-se as difrações em 0,$48 ; 0,29$ e $0,25 \mathrm{~nm}$.

Os piroxênios com sua difração em 0,$44 ; 0,29 ; 0,27 \mathrm{~nm}$ destacam-se mais nos horizontes de rocha, desaparecendo quase que completamente nos horizontes de solo, o que evidência sua degradação em direção ao topo. 


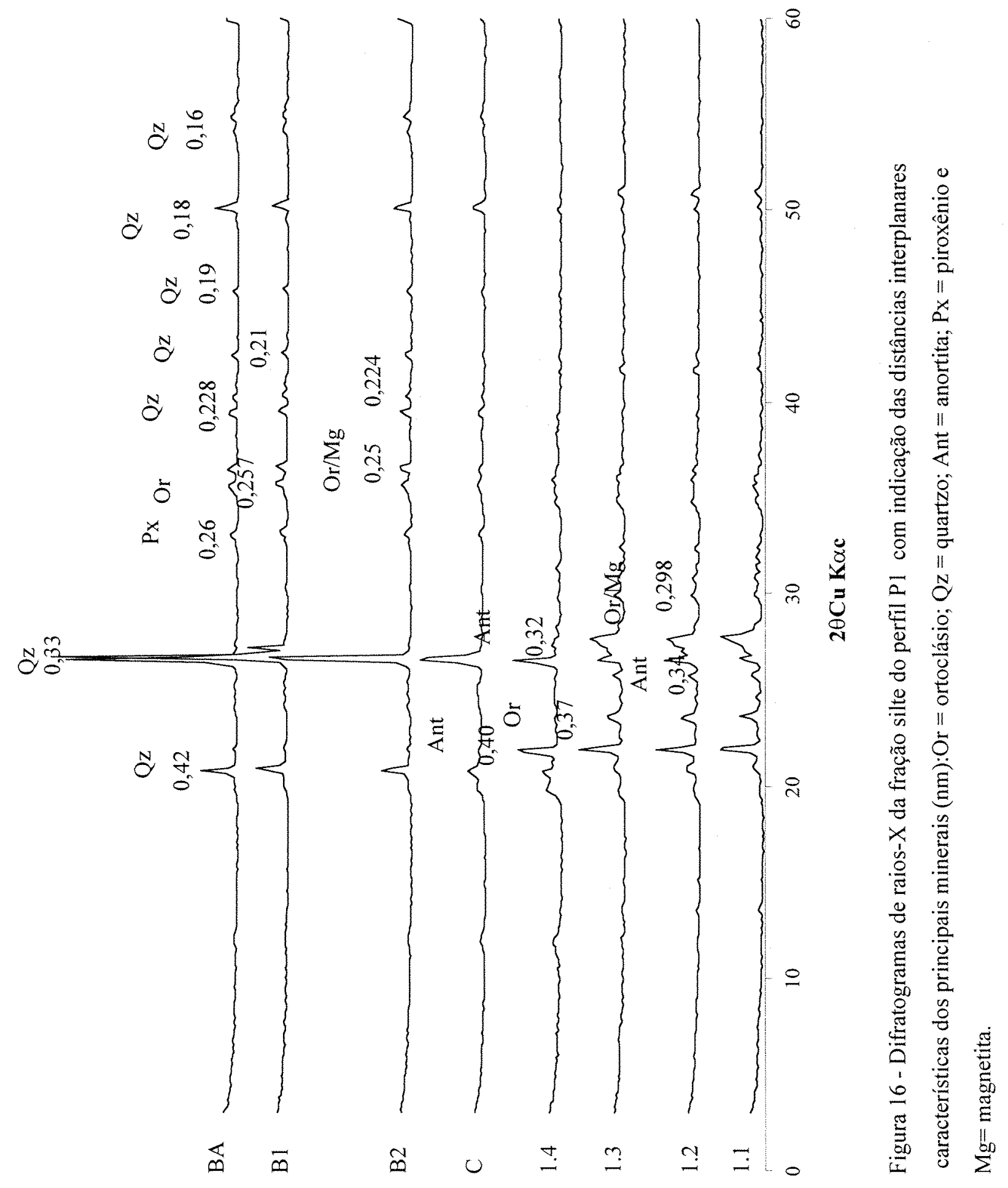




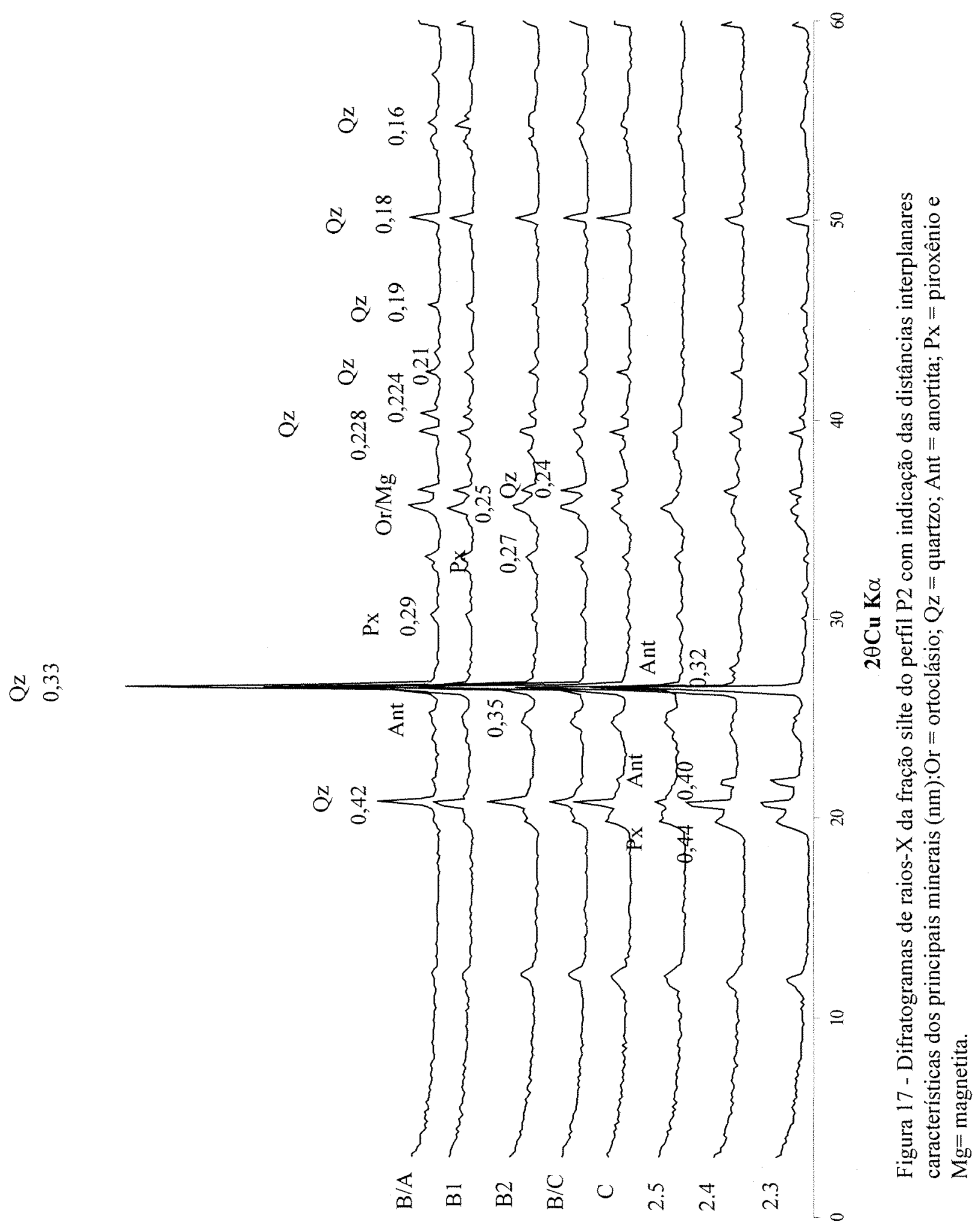




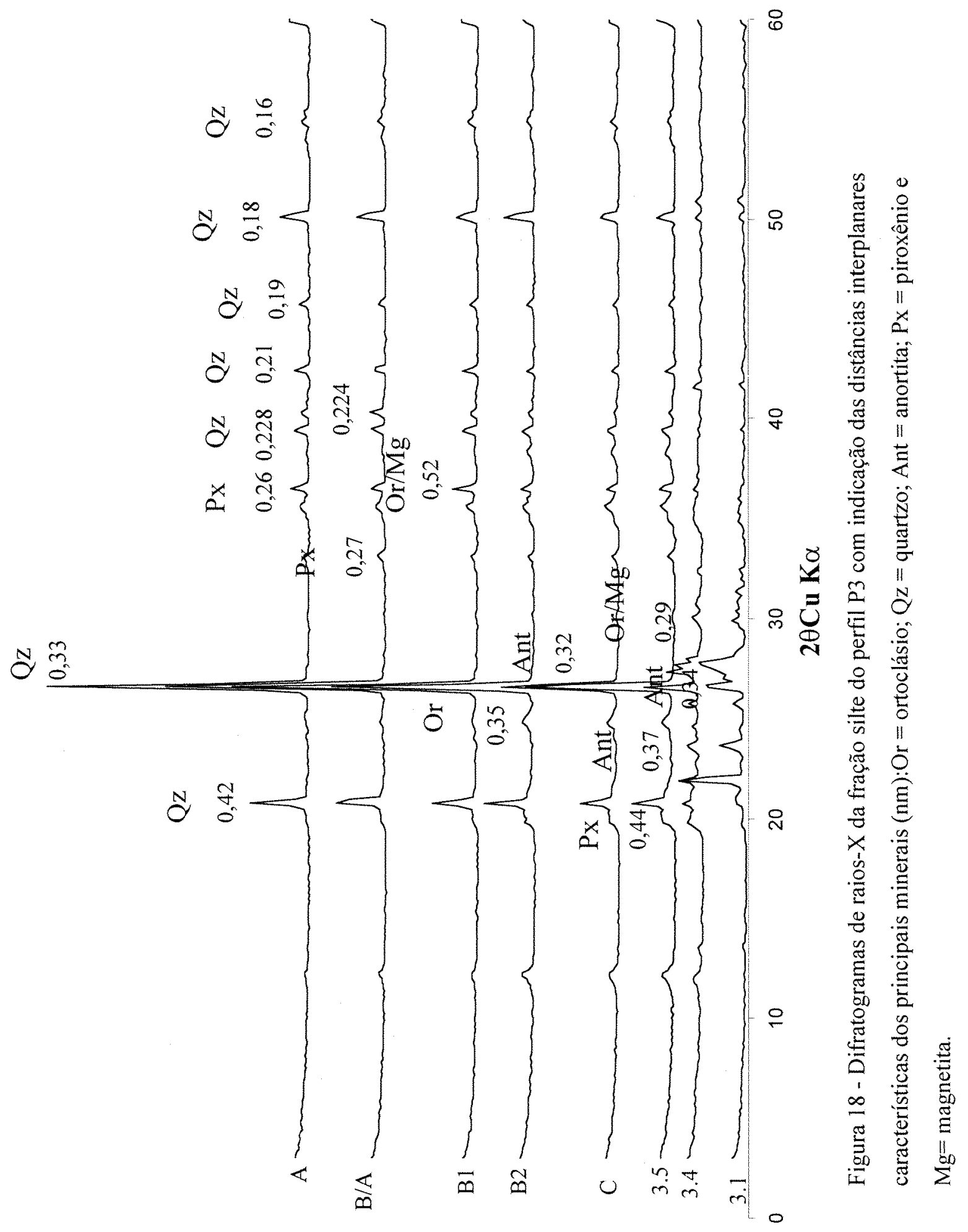




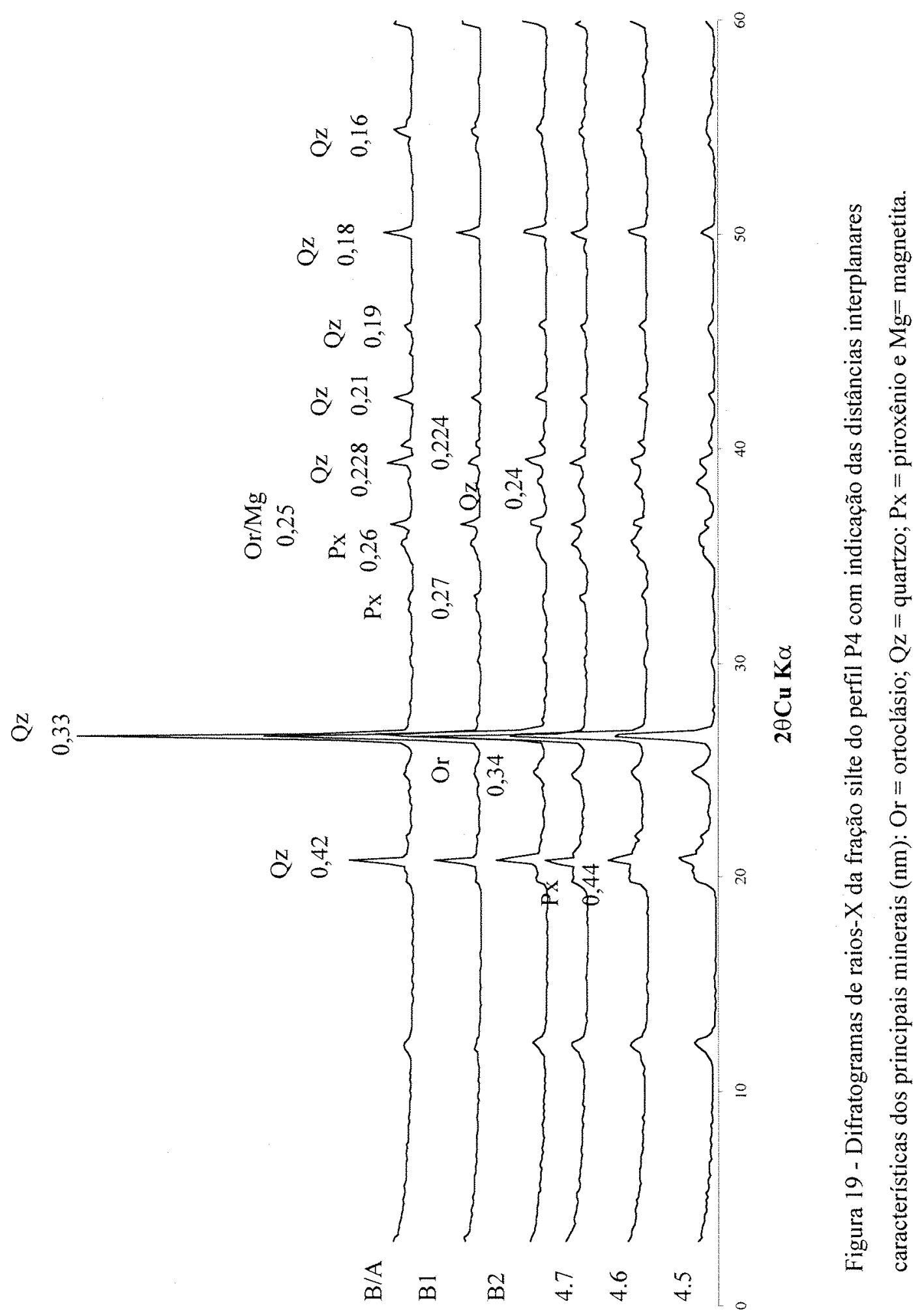




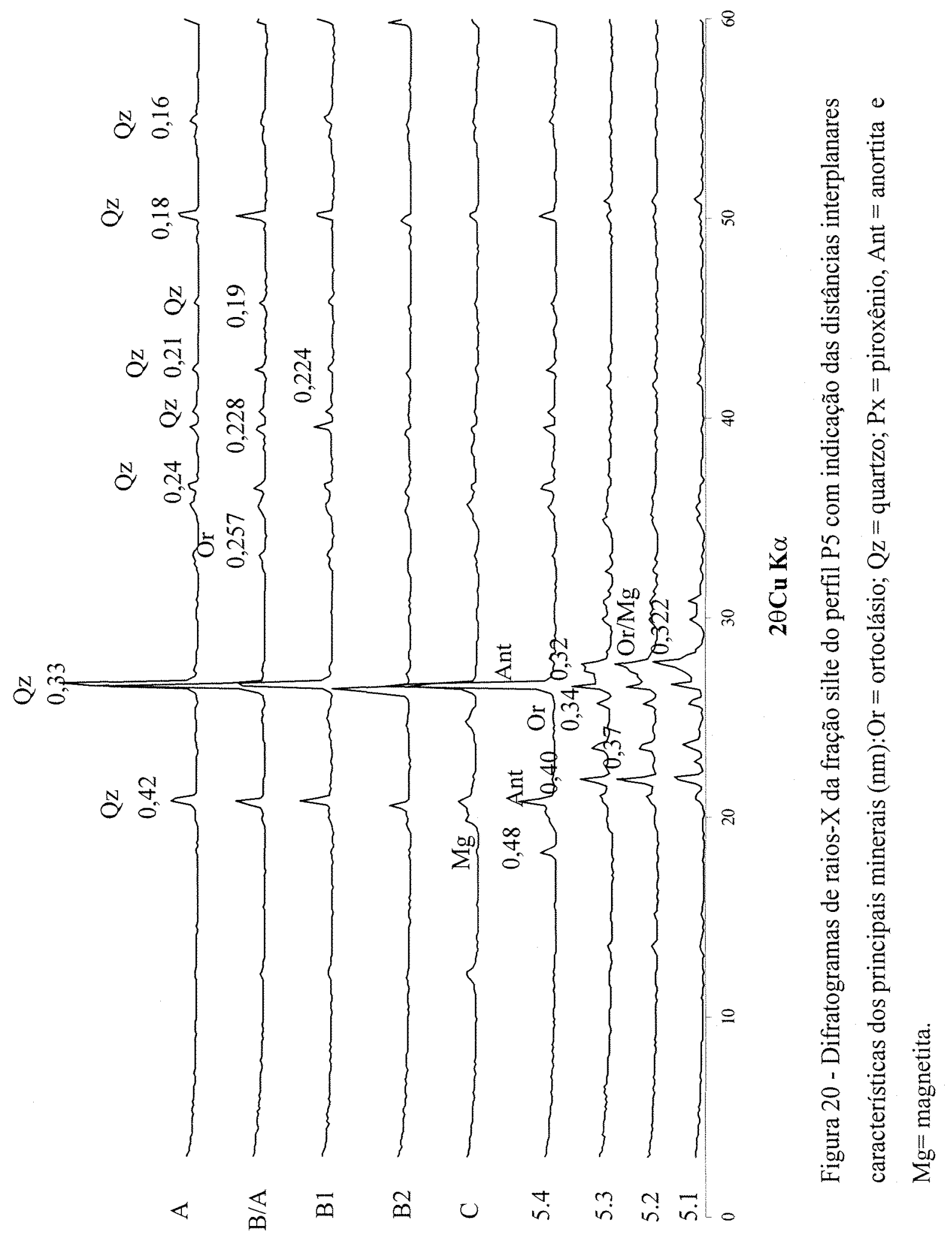


Um padrão mineralógico similar foi observado para a fração areia desse solo, porém nesta o piroxênio e a magnetita estão ausentes, evidenciando sua degradação logo nos primeiros estágios de degradação da rocha (figuras 21 a 25).

O quartzo é o mineral mais abundante e os plagioclásios ocorrem em quantidades intermediárias.

\subsubsection{Análises por microscopia eletrônica de varredura}

A observação dos materiais ao microscópio eletrônico de varredura, juntamente com as microanálise de raios- $X$, complementaram a identificação dos constituintes minerais presentes nas diferentes fases de alteração do riodacito.

Tal estudo foi realizado a partir dos fenocristais de plagioclásio, piroxênios e da matriz das rochas riodacíticas.

É importante o estudo da morfologia e do arranjo de minerais que sofreram alterações pois favorecem melhor o entendimento da transformação de minerais primários sob as condições naturais do campo.

\subsubsection{Alteração dos minerais do grupo dos plagioclásio.}

A alteração de minerais foram detalhadas e descritas por inúmeros autores, entre eles: Leneuf (1959); Bonifas (1959), Delvigne (1965), Lelong (1969), Novikoff (1974) e Boulange (1984) in Clemente (1988). Estes autores mostraram que as alterações dos plagioclásios evoluem de acordo com a situação geográfica da rocha de origem (clima, relevo, etc.) e drenagem interna do perfil onde se encontra o mineral.

Os plagioclásios tendem a desagregar-se logo nos primeiros estádios de alteração, levando a rocha uma perda de coesão.

Esta desagregação se traduz por um sistemas de fraturas, que tendem a se alargar à medida que a alteração progride. 


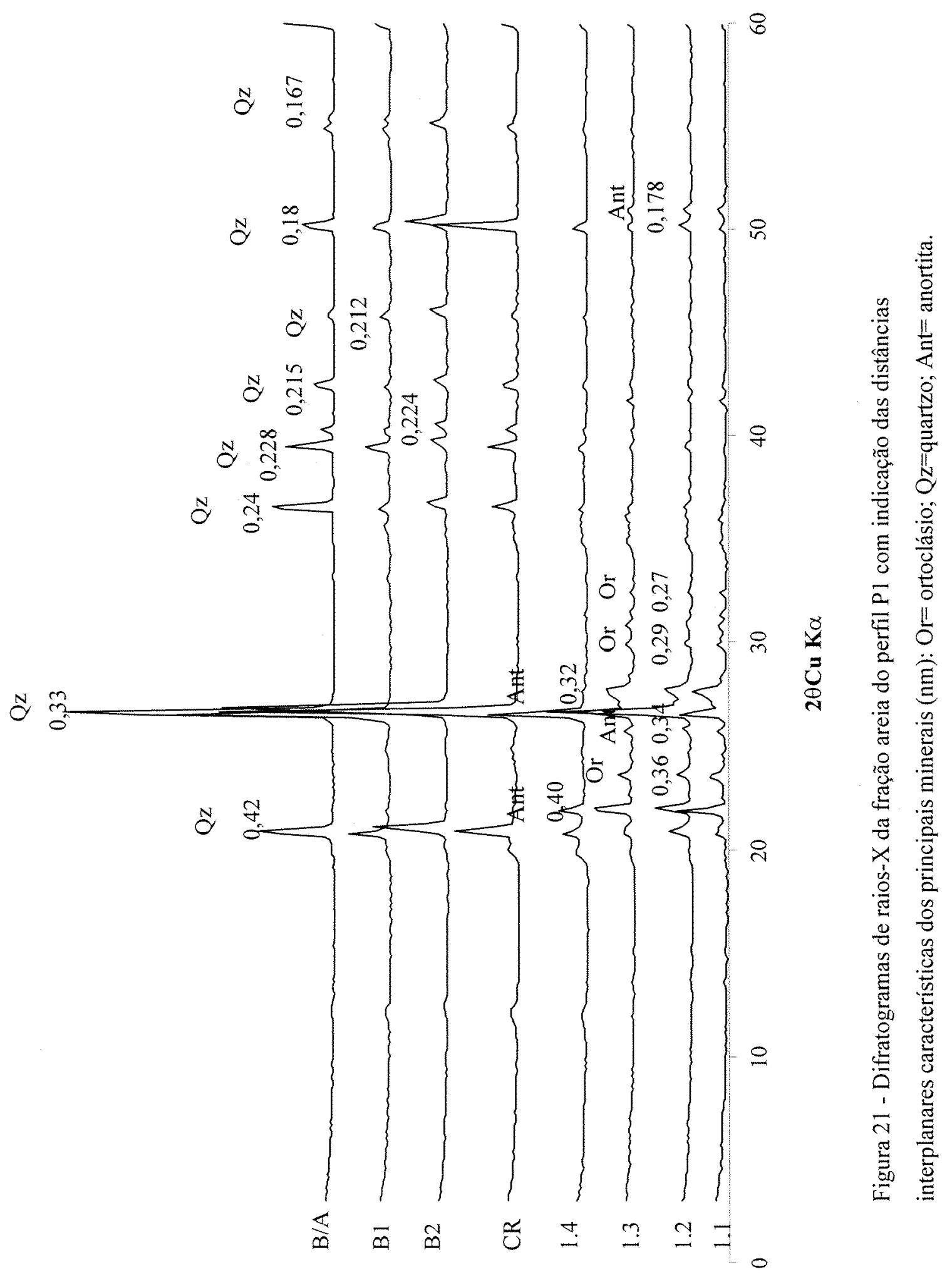




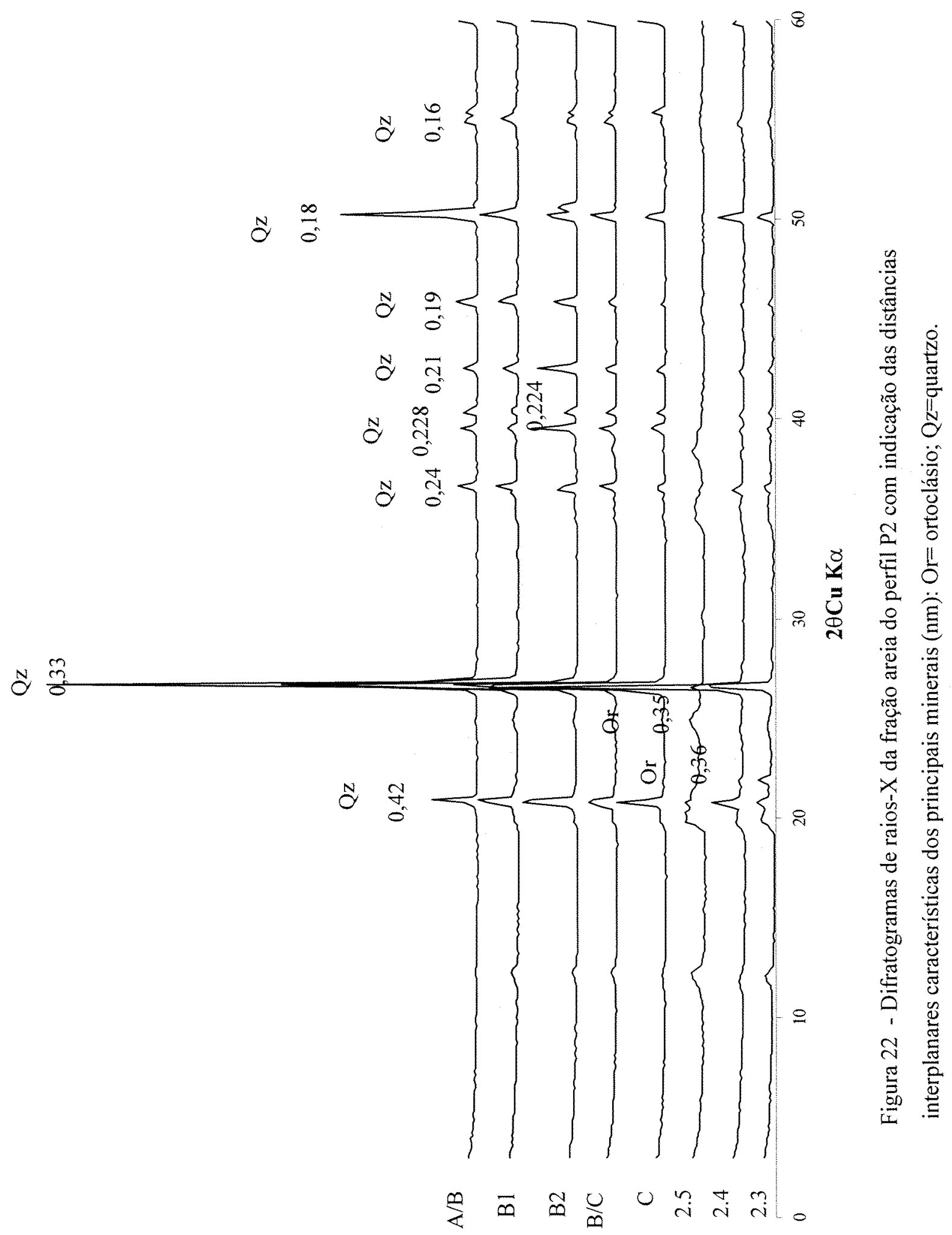




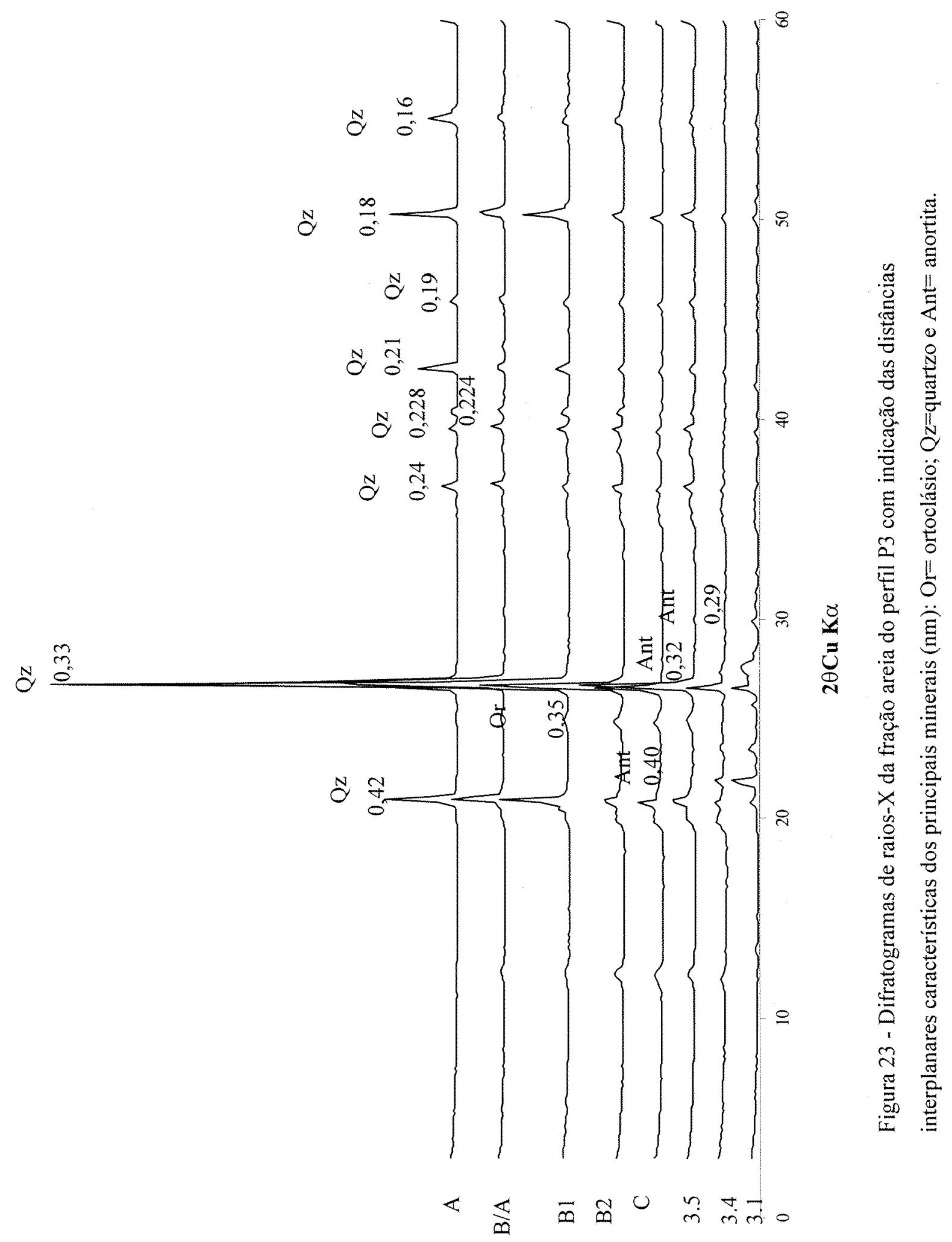




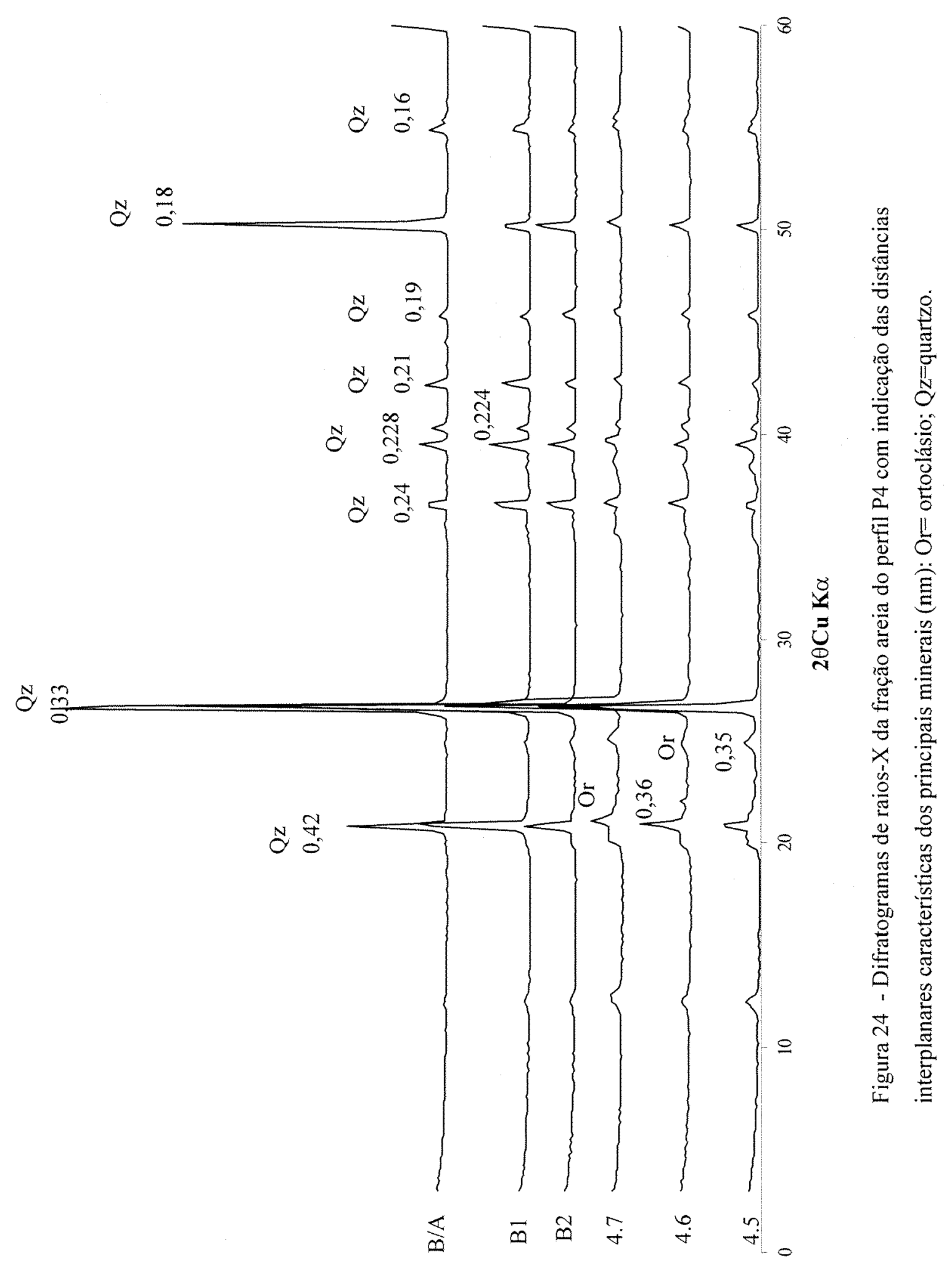




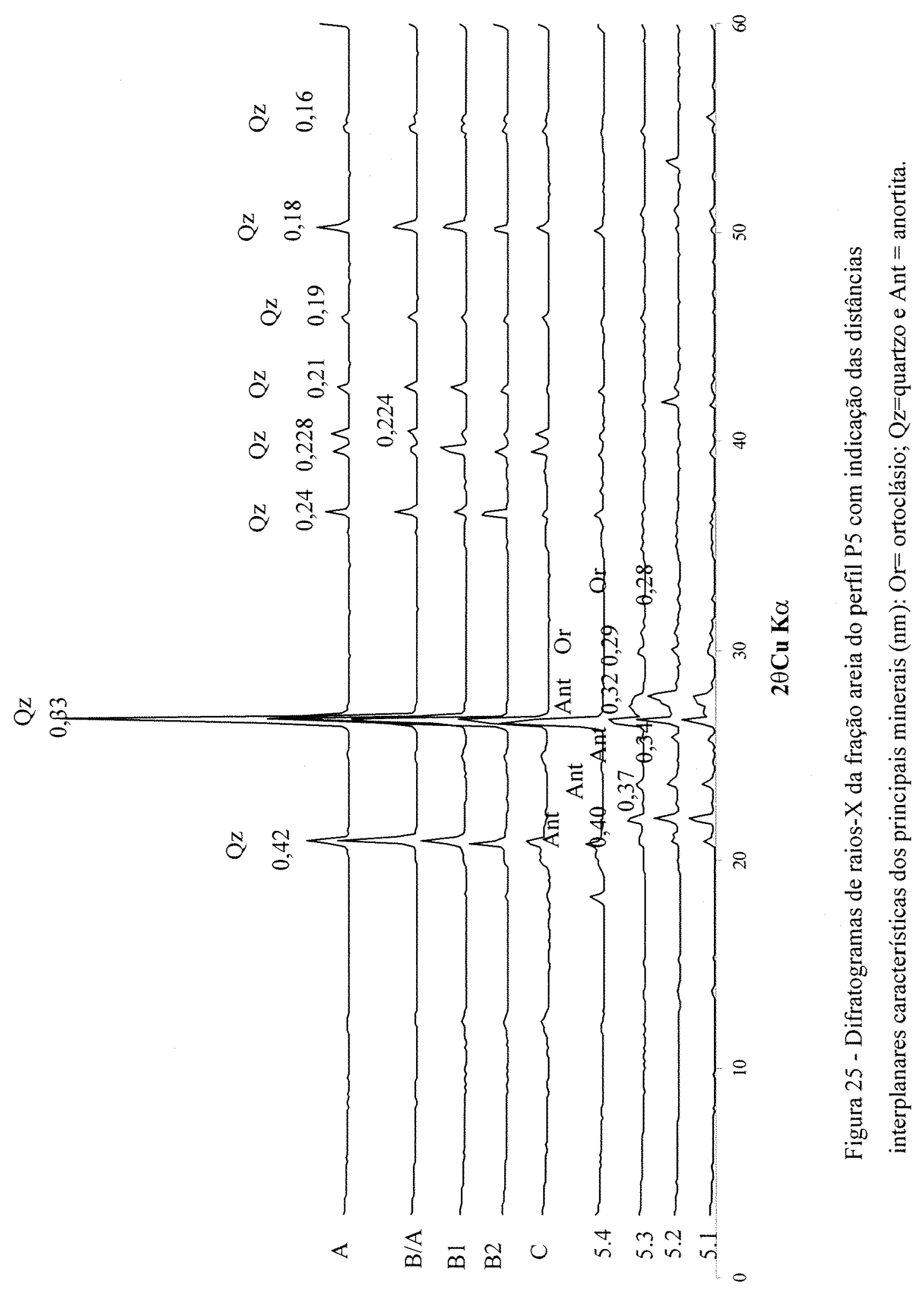


Essas modificações físicas estão intimamente relacionadas com as transformações químicas.

Em condições tropicais úmidas, regiões de elevada pluviosidade e boa drenagem o plagioclásio apresenta um tipo extremo de transformação. Tal alteração do plagioclásio é diretamente para gibbsita (Delvigne, 1965 e Clemente, 1988).

Em condições menos severas de intemperismo, as alterações seguem de outra maneira: plagioclásio $\rightarrow$ geles amorfo $\rightarrow$ gibbsita ou plagioclásio $\rightarrow$ geles amorfo $\rightarrow$ gibbsita + caolinita.

Segundo Delvigne (1965), a rapidez com que as bases e a sílica são eliminadas dos níveis de alteração, determina o aparecimento da gibbsita.

Se a exportação da sílica no ambiente de alteração é mais lento, uma parte da sílica se mantém combinada com o alumínio, causando o retardamento da destruição da estrutura, gerando o aparecimento de uma fase amorfa + caolinita. Esta fase amorfa + caolinita se mantém até a eliminação total do silício, quando se dá o aparecimento dos primeiros cristais de hidróxido de alumínio.

Delvigne (1965), descreve também que em meio ferralítico, os produtos de alteração mais freqüentes dos plagioclásios são os argilominerais 1:1 (caolinita, haloisita e metahaloisita), materiais amorfos até gibbsita quando a dessilificação for mais intensa.

Bellieni et al., 1986b, descreve que os fenocristais de plagioclásio se alteram de maneira uniforme. Em todos os casos, as primeiras manifestações da alteração consistem no aparecimento de finas fraturas, de alguns micrometros de espessuras, sinuosas e que não seguem geralmente os planos de clivagem.

Essas fissuras são as vezes fracamente amareladas ou amareloavermelhadas por hidróxidos de Fe proveniente da alteração dos minerais vizinhos.

Com o avanço da alteração, as finas fraturas sinuosas dividem o plagioclásio em algumas fases distintas. Os espaços entre essas fissuras são preenchidos ora por material isotrópico ora por partes do cristal formando ilhas do plagioclásio inalterado. 
Gonçalves (1987), descreve também que a alteração dos plagioclásios em direção ao cortex, se inicia por uma microfissuração intensa (sem orientação preferencial no cristal) e pelas microexpansões das linhas de clivagem, evidenciadas pela deposição de plasma ocre amarelado, ferruginosos.

Das bordas para o centro, os plagioclásios são pseudomorfeados por um plasma incolor a amarelo-pálido, isotrópico.

Cerri (1979) em seu estudo sobre alteração de minerais sob diferentes condições bioclimáticas concluiu que o comportamento dos plagioclásios em clima subúmido no Estado de São Paulo, são mais sensíveis á alteração. Já na rocha pouco alterada é possível detectar os primeiros sinais de sua decomposição. Nos primeiros estádios de alteração da rocha não é somente em gibbsita que se transformam os plagioclásios, mas também em caolinita.

Em clima subtropical úmido de altitude (Sul do Estado de São Paulo e Paraná), Cerri (1979) determinou que estes minerais apresentam uma fase micácea muito nítida quando presentes na faixa de transição entre rocha e camada alterada.

Quando presentes na camada alterada, os minerais estão praticamente desestruturados internamente, porém a sua forma externa permanece conservada. Podese esquematizar então, que a alteração no estado do Paraná se dá da seguinte forma:

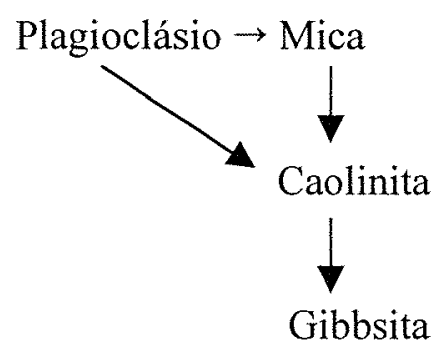

Cerri, 1979, concluiu também que em clima temperado úmido (Estado do Rio Grande do Sul), as condições hidrolíticas são menos acentuadas que aquelas atuantes no Estado do Paraná, não se registrando assim a presença de gibbsita. Desta 
maneira, a caolinita constitui-se o mineral mais estável neste tipo de clima permanecendo então:

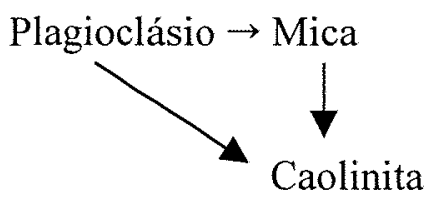

Bouabid et al., 1995, descreve que a interpretação do intemperismo dos plagioclásios é muito complexa pois estes apresentam uma grande variabilidade composicional.

Os resultados obtidos no estudo dos plagioclásios dos riodacitos da topossequência estudada não fogem as regras descritas pelos autores citados anteriormente.

De uma maneira geral, os fenocristais de plagioclásio da topossequência Timburi se alteram de uma maneira aproximadamente uniforme. As primeiras manifestações de alteração consistem no aparecimento de finas fraturas, de alguns micrometros de espessura e que não seguem geralmente os planos de clivagem.

Essas fissuras são as vezes fracamente amareladas ou amareloavermelhadas proveniente da alteração de minerais vizinhos (fotomicrografia 2).

Uma segunda evidência de alteração conclui que o comportamento dos plagioclásios seja sua alteração para caolinita e secundariamente em mica e haloisita, isto é, quando as condições de intemperismo não forem muito intensas (fotomicrografia $3)$.

Quando em condições severas de intemperismo, isto é, quando o processo de alitização for bastante intenso, é possível detectar a decomposição dos plagioclásios em gibbsita (fotomicrografia 4). A análise química qualitativa evidencia o aparecimento somente do pico de $\mathrm{Al}$ e praticamente não se observa o de Si.

As fotomicrografias que serão apresentadas a seguir mostram as várias formas dos cristais de plagioclásio. Pode-se observar um aspecto em forma de pente no conjunto todo e também estrutura em "boxwork" (fotomicrografia 5). Nota-se também 


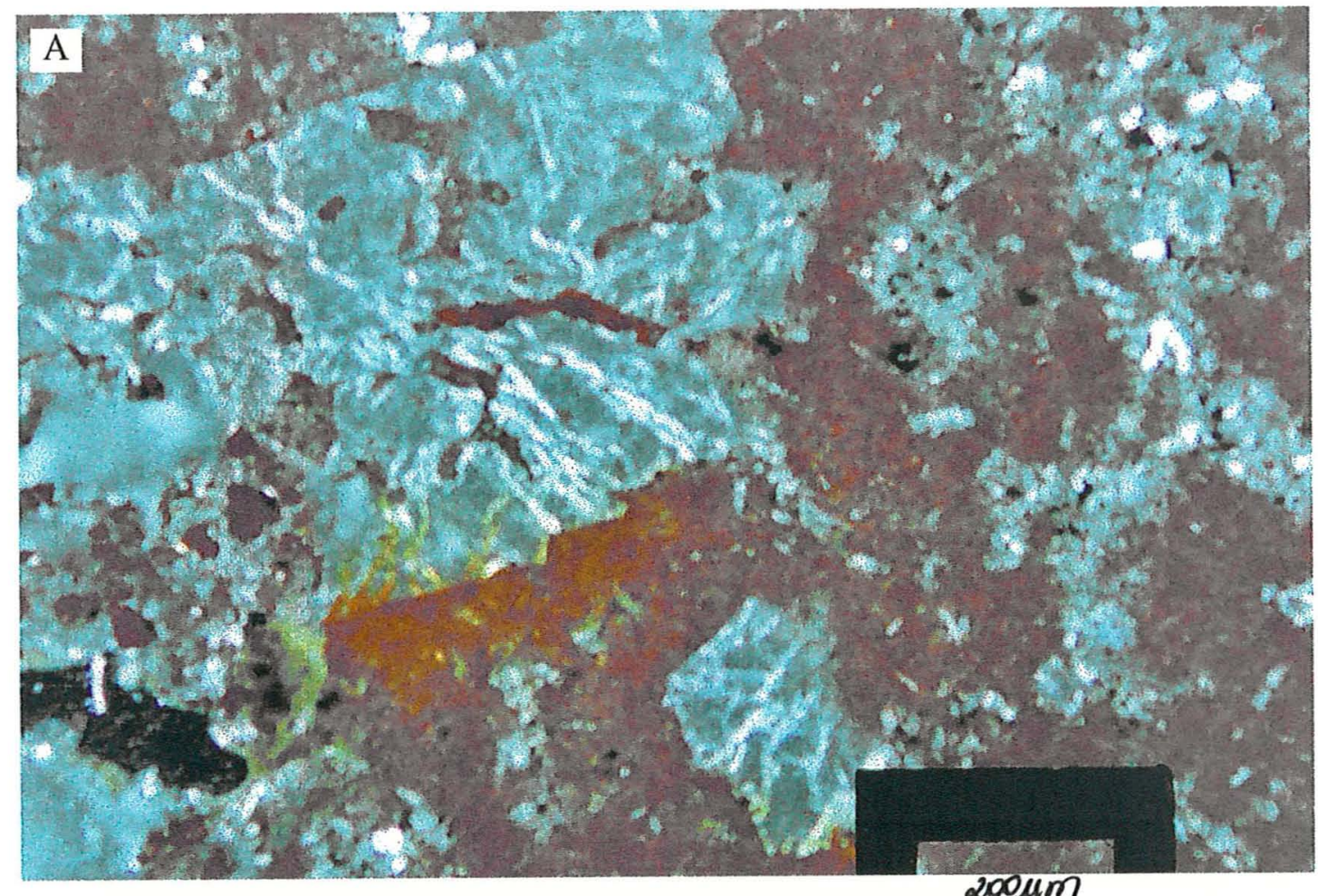

$200 \mu \mathrm{m}$

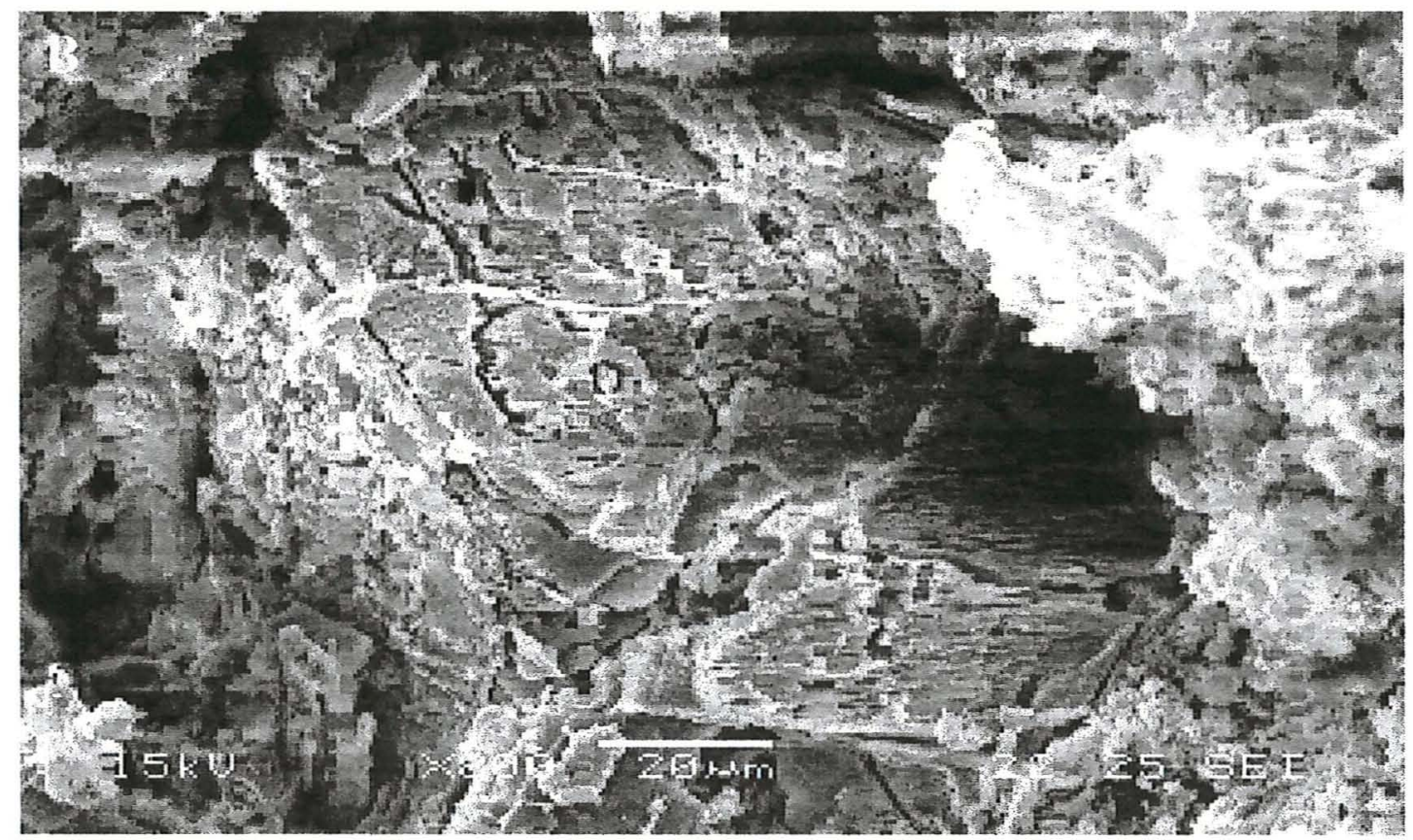

Fotomicrografia 2 - A) Microscópio óptico, luz polarizada e nicóis cruzados com aumento de x 2,5. Início da alteração do plagioclásio em finas fraturas de algumas micrometros de espessura; B) Microscópio Eletrônico de Varredura, também mostrando finas fraturas preenchidas por outros materiais. 

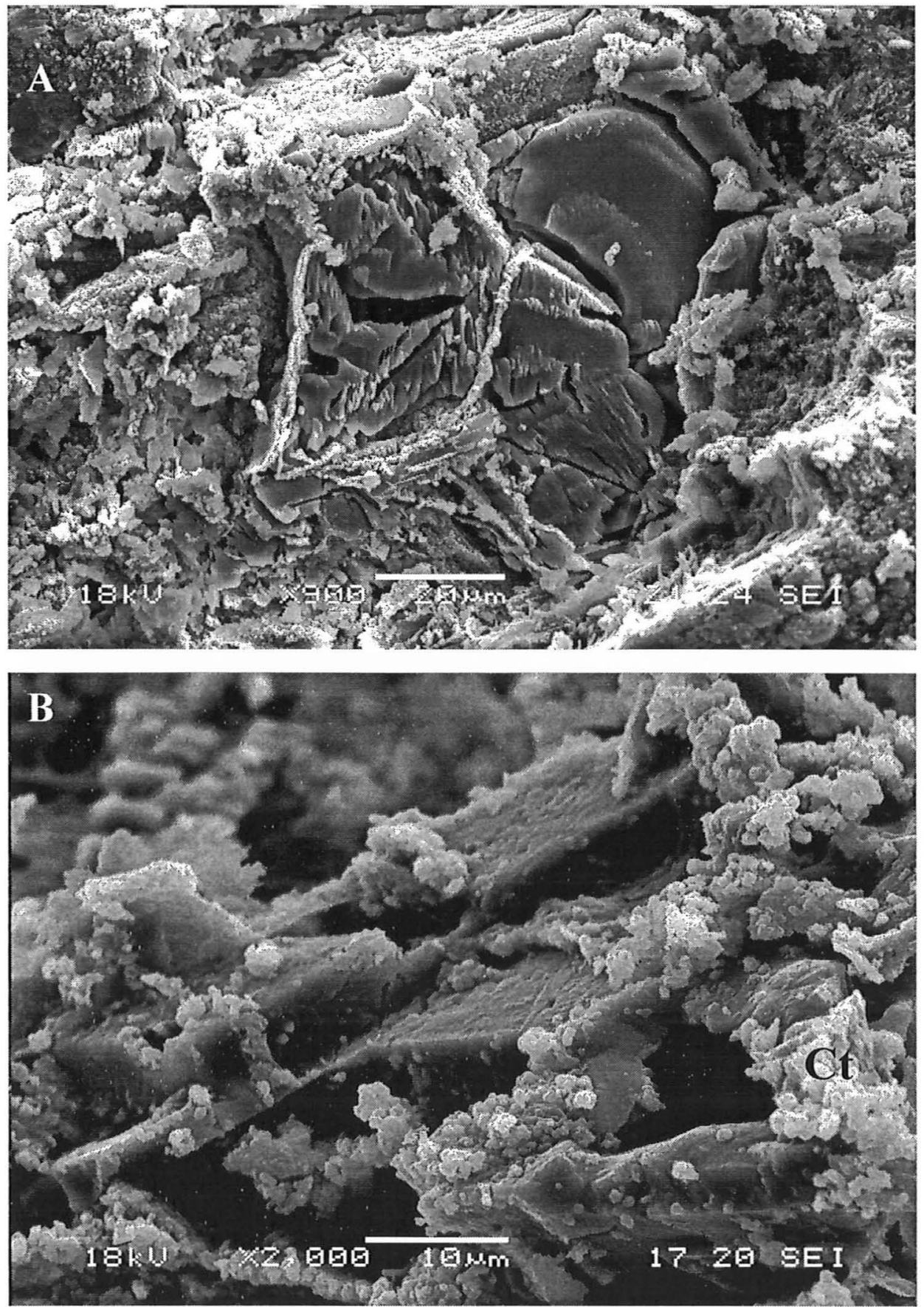

Fotomicrografia 3 - A) Microscópio Eletrônico de Varredura, detalhe da alteração do plagioclásio ocorrendo na superfície de clivagem do cristal; B) Microscópio Eletrônico de Varredura, detalhe de outro plagioclásio sofrendo alteração, mas do centro em direção a borda do cristal. Os espaços deixados são preenchidos totalmente por caolinitas $(\mathrm{Ct})$. 

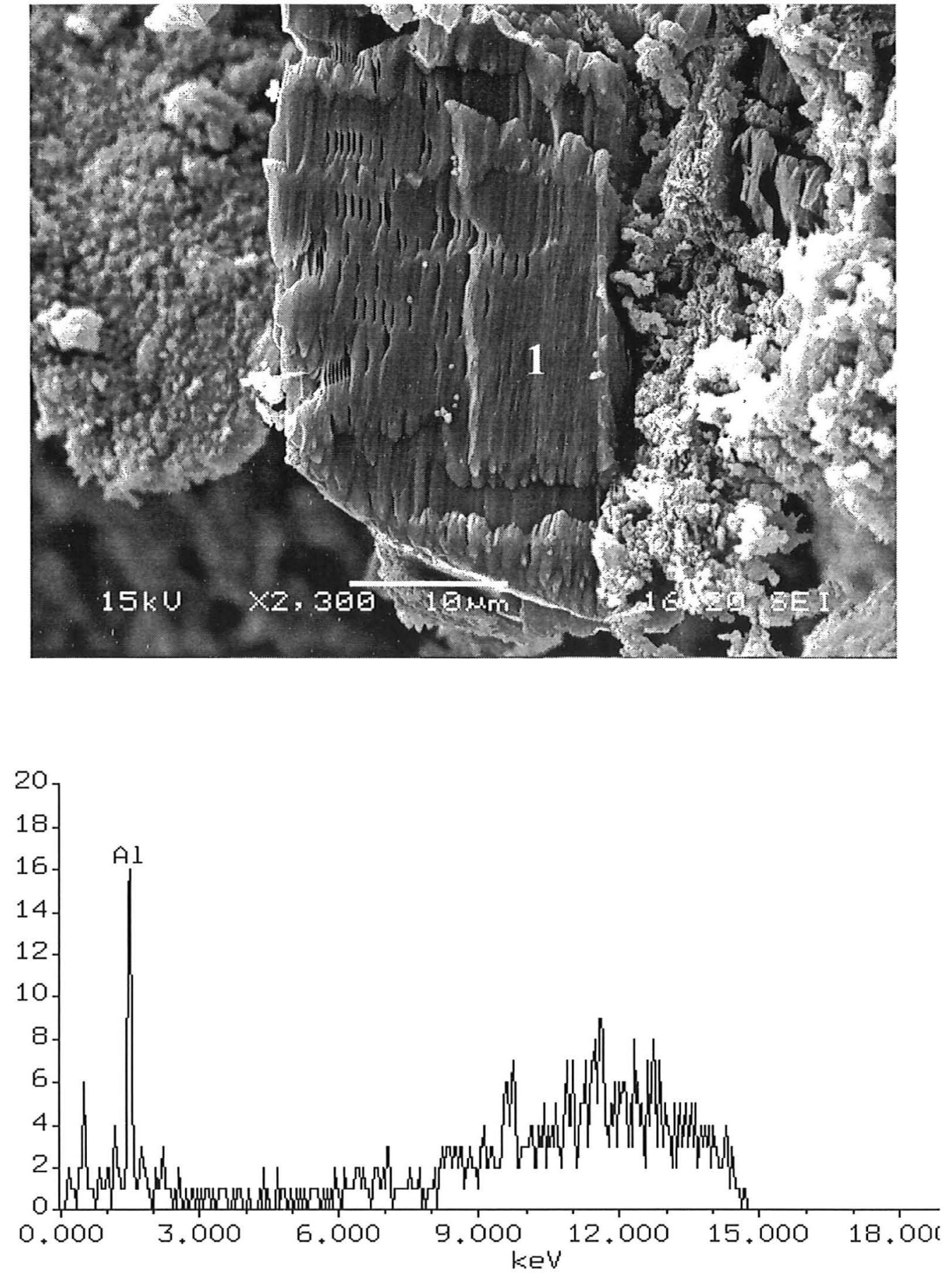

Fotomicrografia 4 - Microscópio Eletrônico de Varredura, plagioclásio transformado totalmente em gibbsita. Observe as linhas de dissolução. O ponto 1 refere-se a análise química qualitativa pontual realizada neste cristal. (amostra da alteração 3.4). 


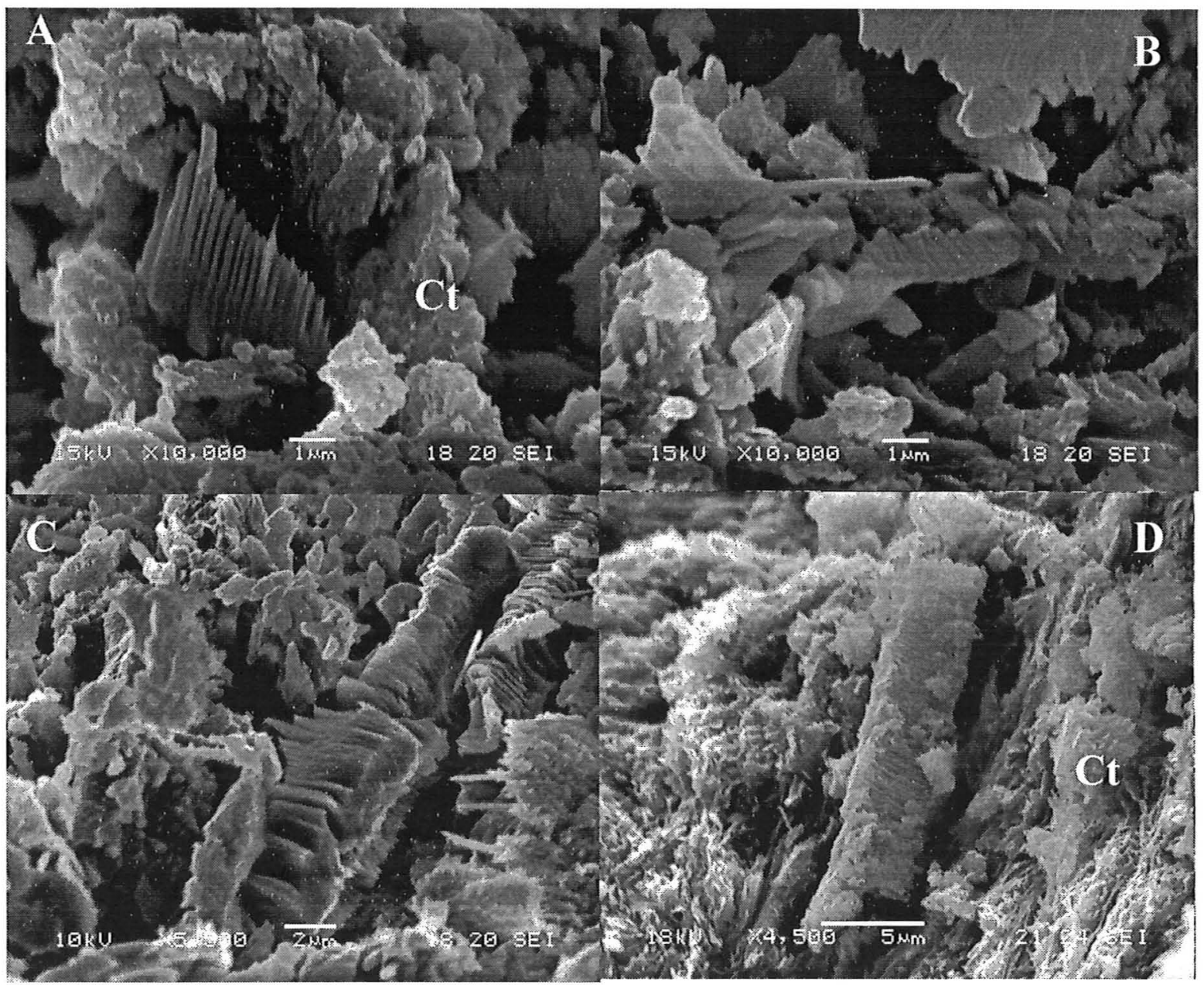

Fotomicrografia 5 - A, B, C e D - Análises com Microscópio Eletrônico de Varredura. Os plagioclásios apresentam estrutura em forma de pente sendo envolvidos por cristais de caolinita $(\mathrm{Ct})$ e mica. 

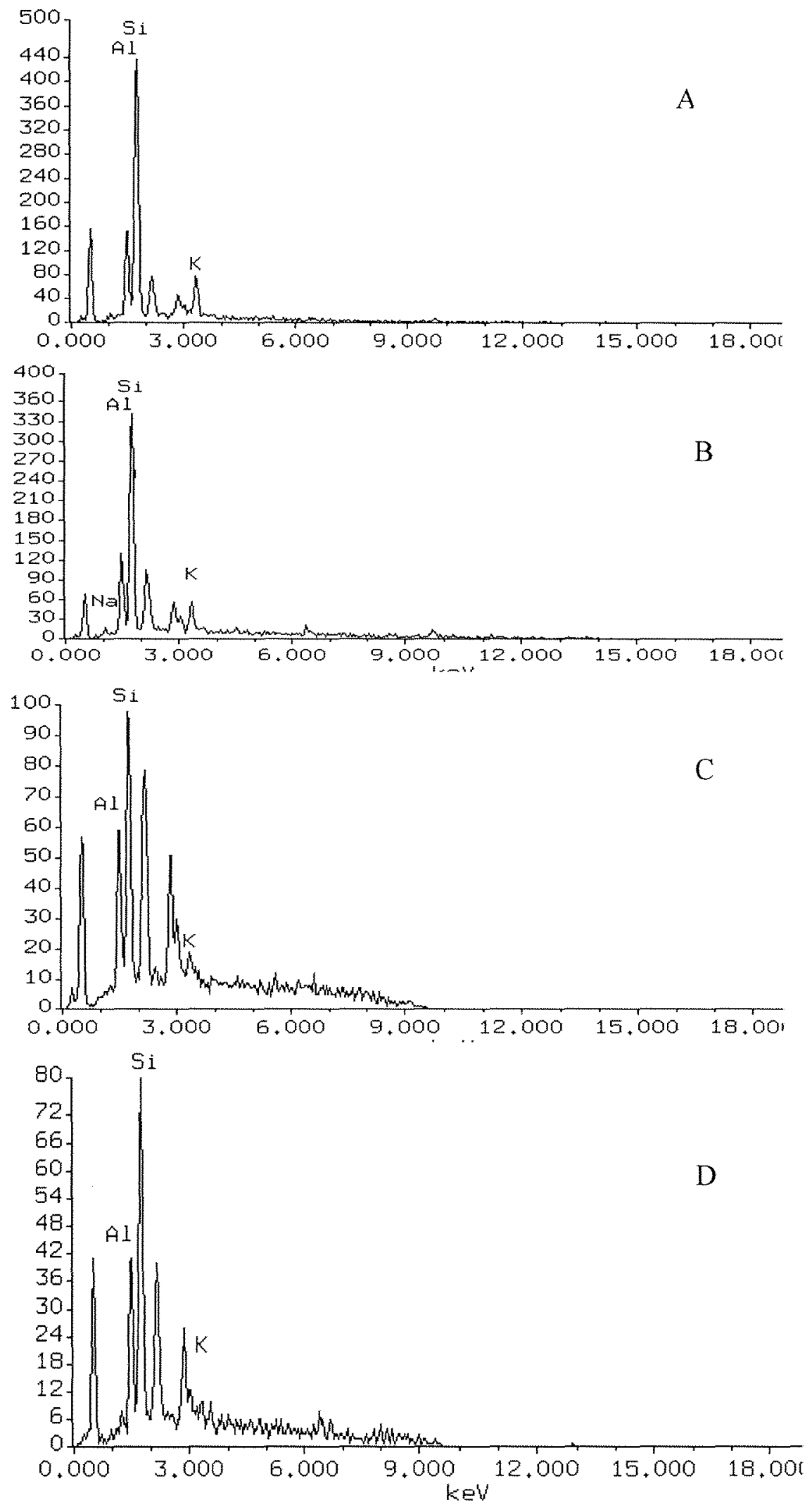

Figura 26. Análise química qualitativa nas diferentes formas apresentadas na fotomicrografia 5 . Os picos de $\mathrm{K}$ sugerem a ocorrência de mica. 


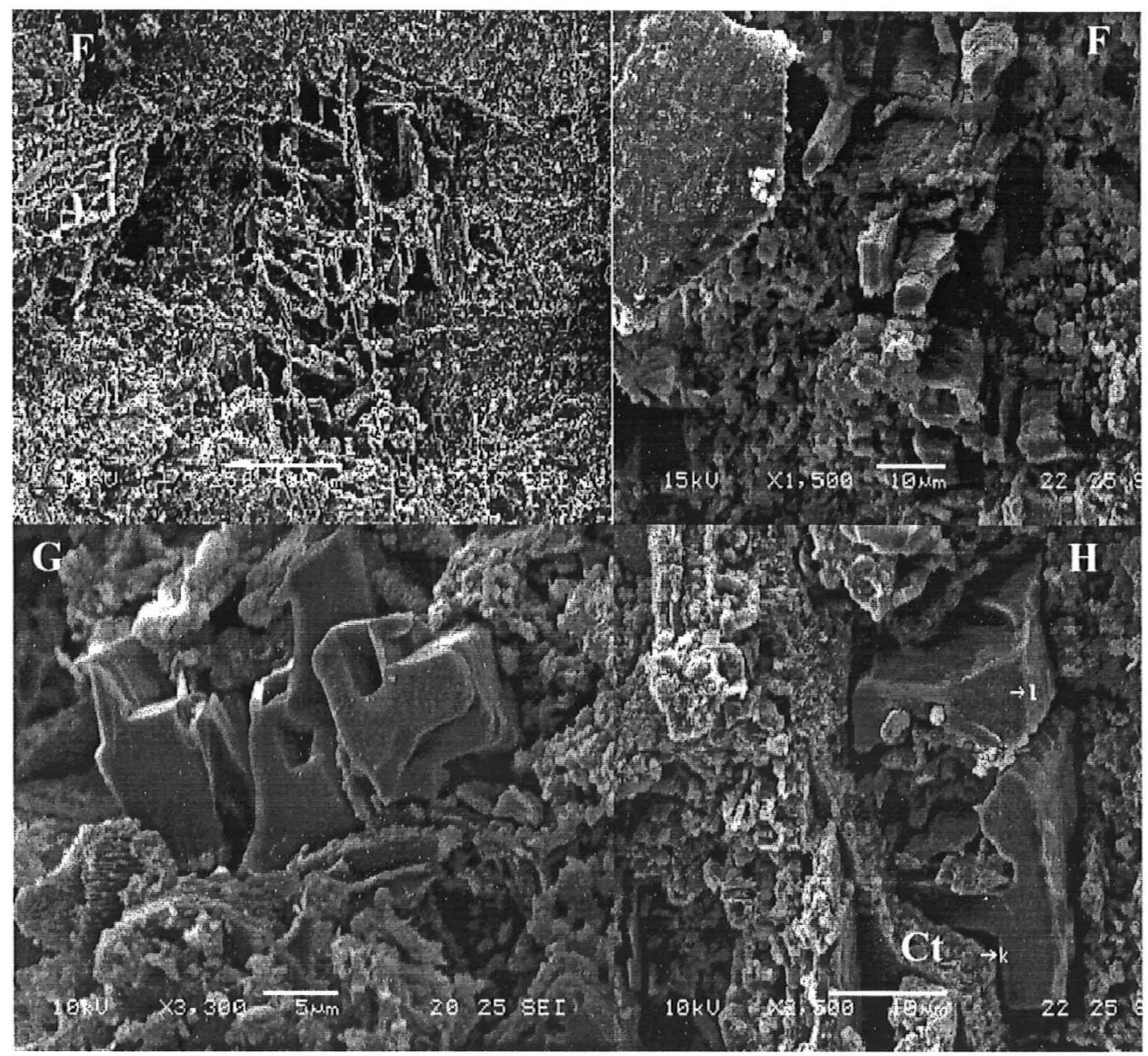

Continuação da fotomicrografia anterior, continuando os plagioclásios envoltos por cristais de caolinita. Na fotomicrografia E encontramos a estrutura em "Boxwork" do plagioclásio alterado. $\mathrm{Na}$ fotomicrografia $\mathrm{H}$ observa-se que a alteração se dá na superfície de clivagem do mineral e no centro do cristal, onde a caolinita está presente. Os pontos $\mathrm{k}$ e 1 correspondem a análise química qualitativa pontual realizada na amostra. 

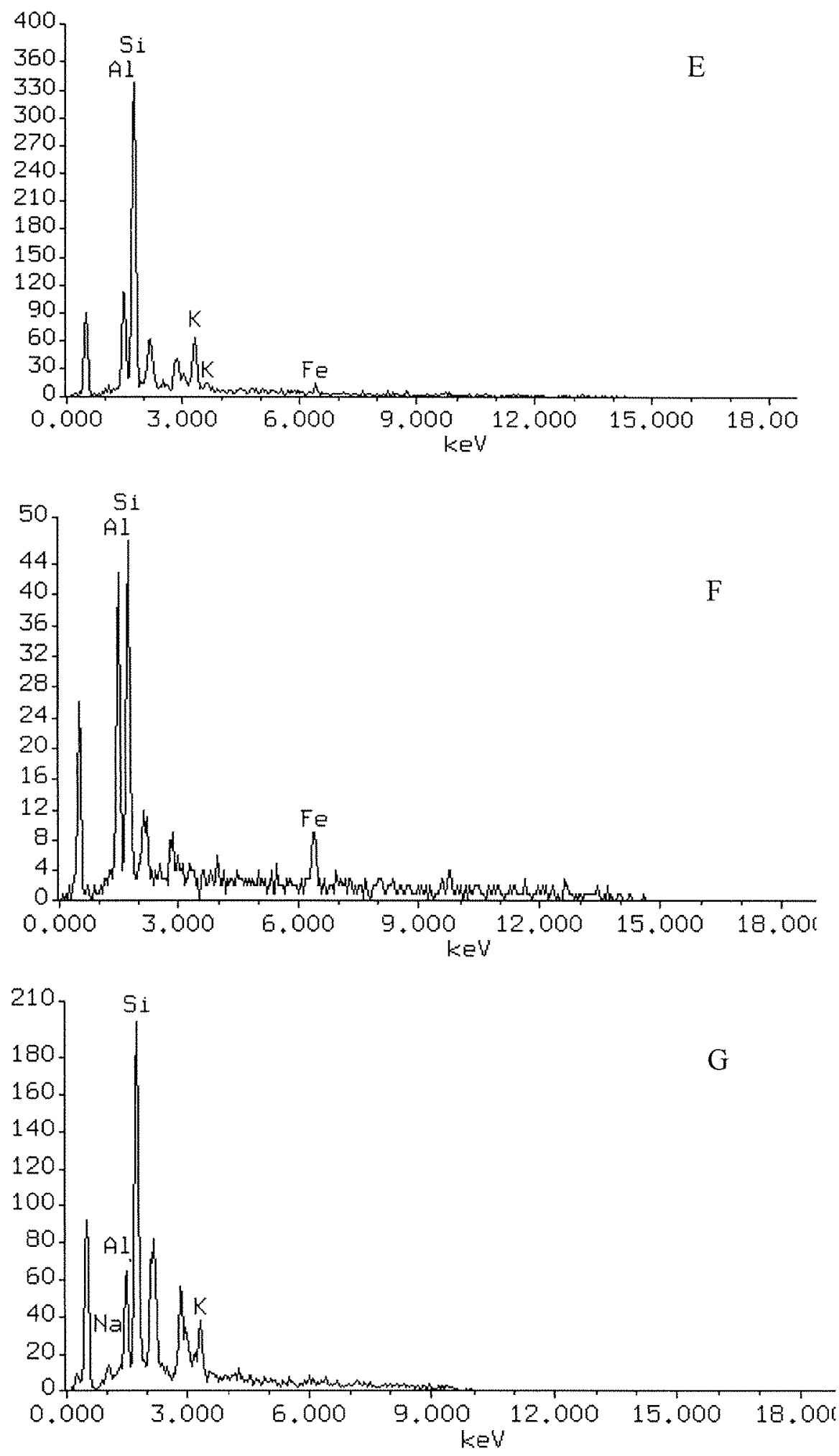

Continuação da Figura 26. Os picos de $\mathrm{K}$ sugerem a ocorrência de mica e os picos praticamente iguais de Al e Si sugerem a presença de caolinita. 

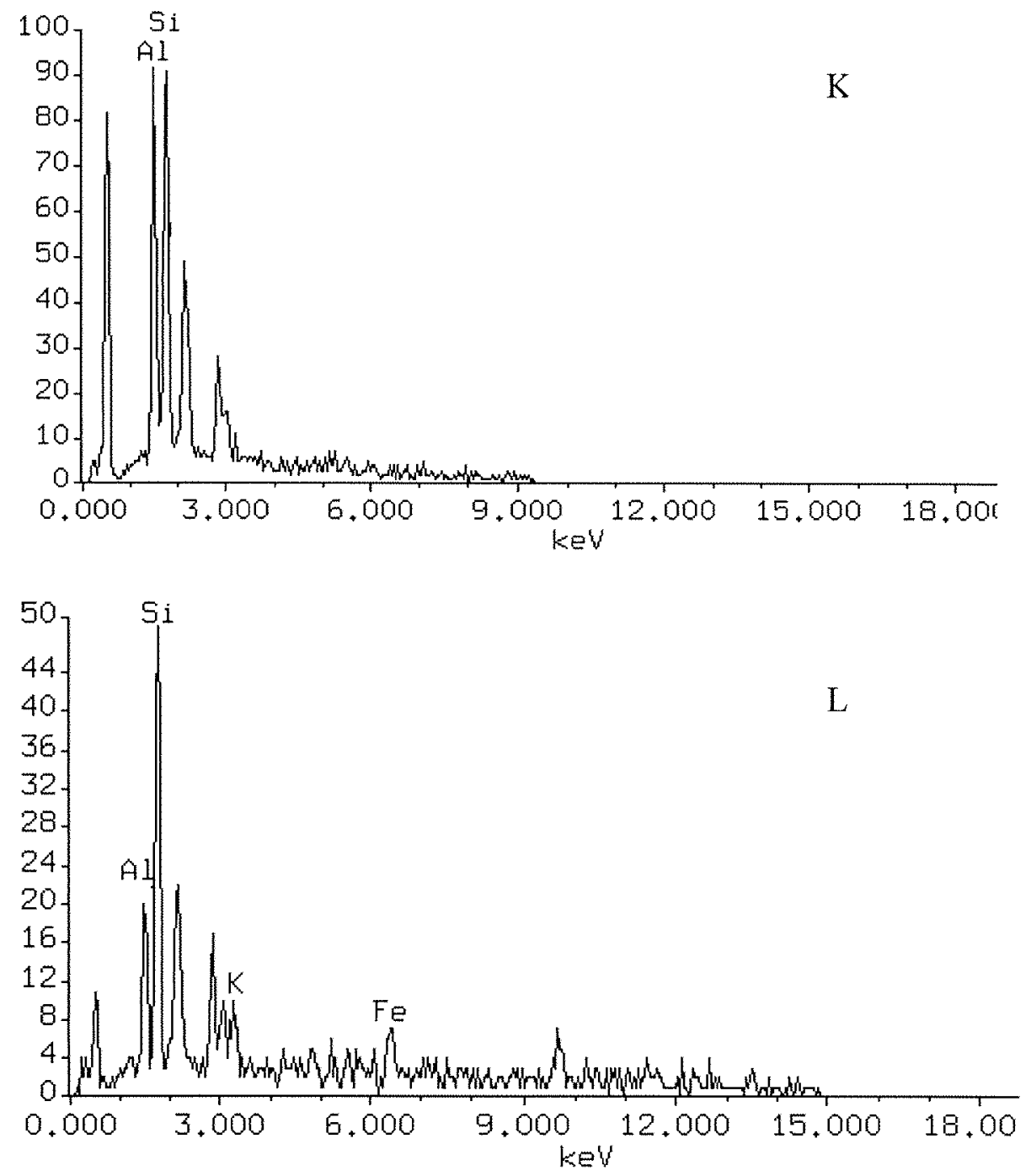

Continuação da Figura 26. Os picos de K sugerem a ocorrência de mica e os picos praticamente iguais de $\mathrm{Al}$ e $\mathrm{Si}$ sugerem a presença de caolinita. 
que a dissolução dos plagioclásios se dá na superfície de clivagem do mineral e do centro em direção a borda do cristal. A relação das análises químicas pontuais da microscopia eletrônica associada com a morfologia dos cristais obtidos no microscópio eletrônico colocou em evidência a ocorrência de caolinita, também evidenciada pela ocorrência de picos de $\mathrm{Al}$ e Si praticamente equivalentes. A presença do elemento $\mathrm{K}$ nas análises químicas indica que o mineral possa estar se alterando para mica (figura 26).

Glasmann \& Simonson, 1985, acreditam que nessa dissolução dos plagioclásios, formam cavidades e que a goethita é formada na superfície dessas cavidades. Isto pode ser observado na fotomicrografia 6.

De acordo com Grim 1968, a caolinita é o mineral de argila mas comum e pode ser identificada pelo formato hexagonal em placas característica. Os cristais de caolinita se encontram distribuídos ao acaso, formando uma matriz com aspecto granular (fotomicrografia 7).

$\mathrm{Na}$ figura 28 referente a fotomicrografia 7, pode-se observar que na análise química global de toda a amostra o pico de Si é relativamente mais intenso que o pico de $\mathrm{Al}$ e na análise química pontual o pico de $\mathrm{Si}$ e $\mathrm{Al}$ são praticamente iguais, levando a supor a ocorrência de caolinita.

\subsubsection{2 - Alteração dos minerais do grupo dos piroxênios.}

Os processos de alteração dos piroxênios foram estudados por vários autores. A maioria desses estudos mostraram grande diversidade de seus produtos de alteração. Entre eles Eswaran (1979) cita que em condições básicas (drenagem imperfeita) os piroxênios se alteram em esmectitas e materiais amorfos e em goethita e gibbsita em ambientes ácidos. Delvigne (1983), descreve a formação de talco e esmectitas em condições hidrotermais e de caolinita, hematita, hidróxidos de ferro por evolução supérgena.

A transformação do piroxênio em goethita é a característica mais marcante. Ela é apontada por Delvigne (1965) como o produto de alteração ferralítica determinada por uma forte drenagem interna. 

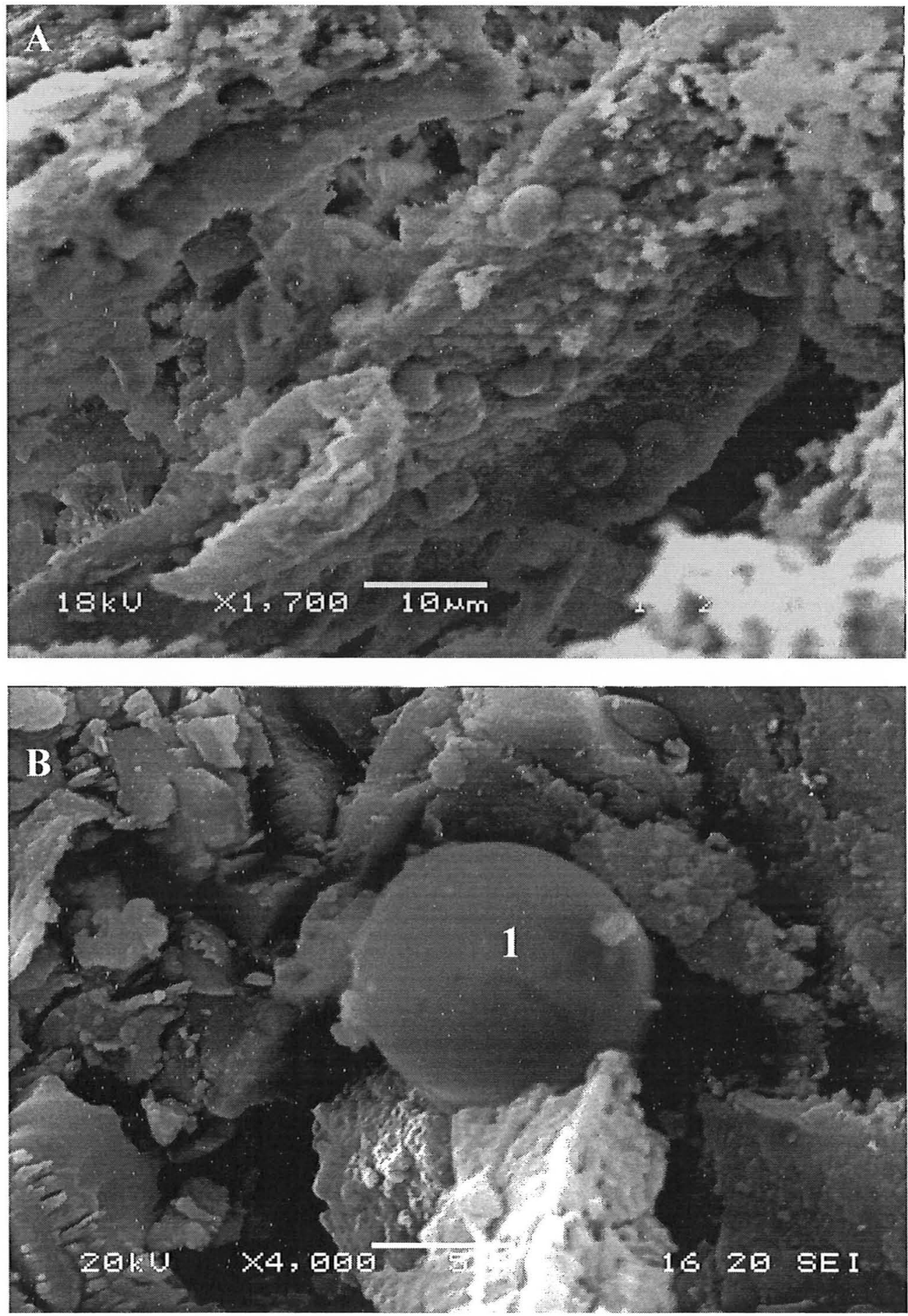

Fotomicrografia 6 - A) Microscópio Eletrônico de Varredura goethitas de hábito mamelonar que se encontram nas cavidades de dissolução dos plagioclásios; B) Detalhe maior da goethita. O ponto 1 refere-se a análise química qualitativa pontual realizada nesta amostras. 


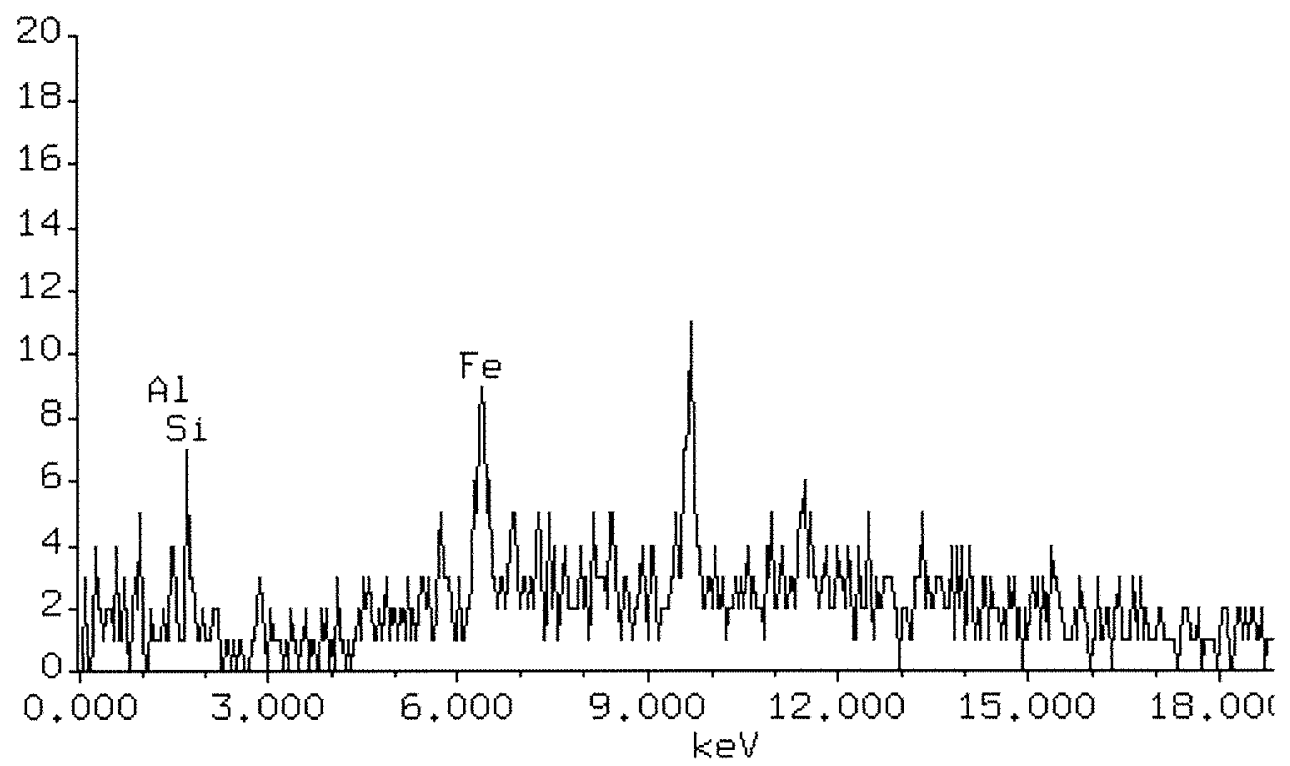

Figura 27. Análise química qualitativa pontual no cristal de goethita de hábito mamelonar correspondente a fotomicrografia 6. 


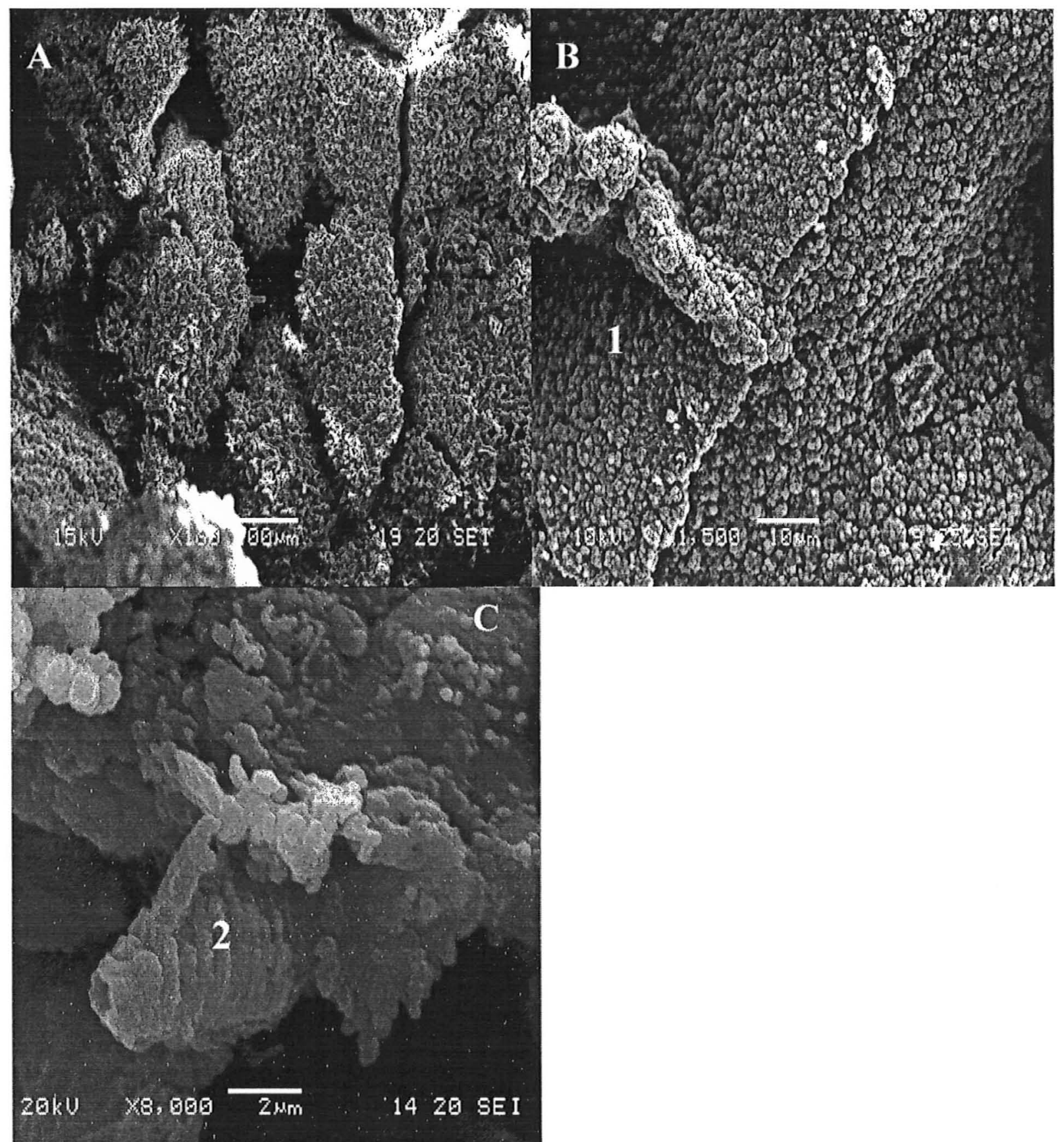

Fotomicrografia 7 - A e B - Análise ao Microscópio Eletrônico de Varredura, mostrando que as caolinitas se encontram distribuídos ao acaso, formando uma matriz com aspecto granular; C) cristal de caolinita identificada pelo formato hexagonal. Os pontos 1 e 2 referem-se as análises químicas qualitativa pontual da amostra. 

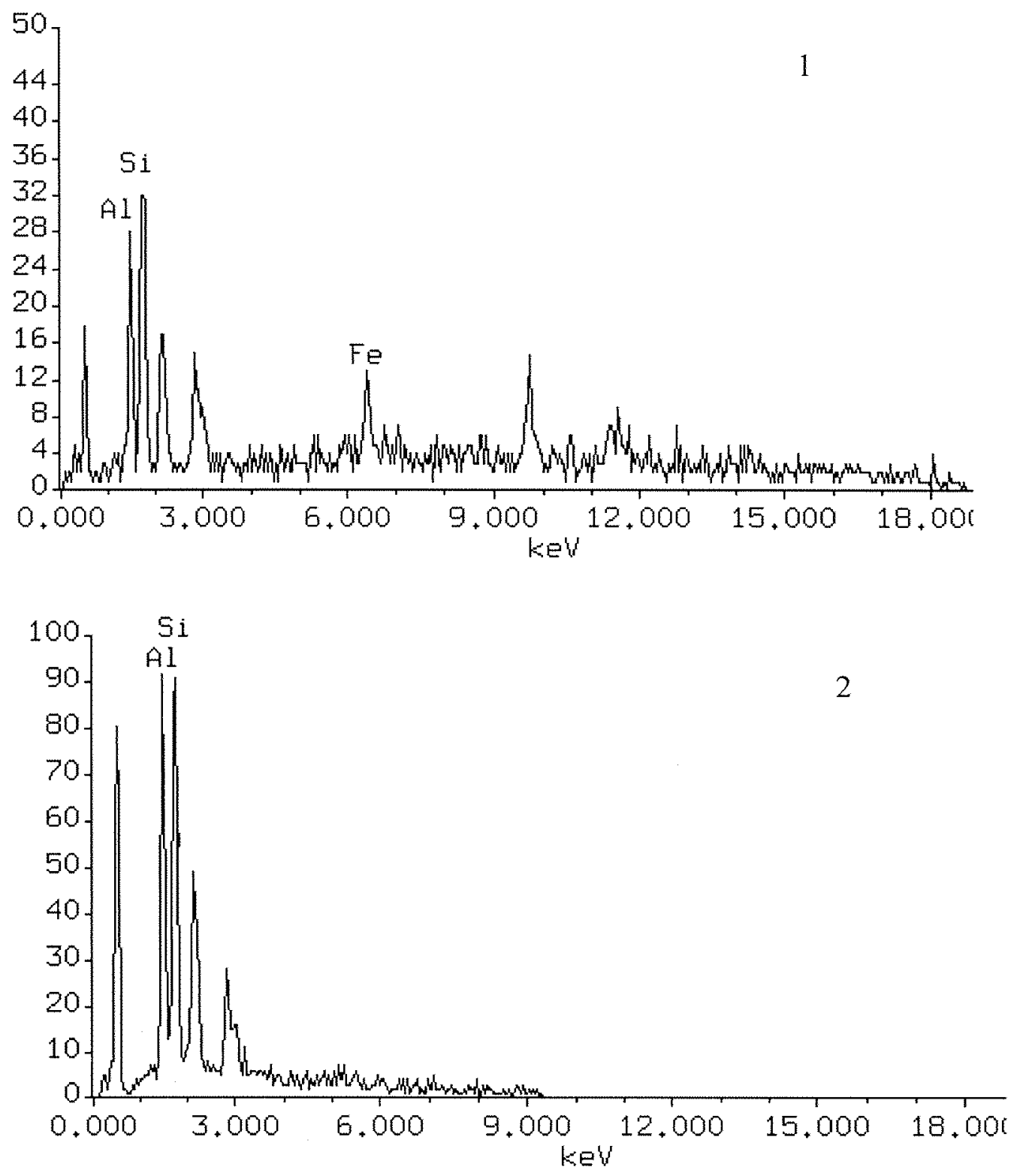

Figura 28. Análise química global e pontual nas caolinitas da fotomicrografia 7.

1- Análise química global de todo o campo da fotomicrografia. O pico do Si é relativamente mais intenso que o do $\mathrm{Al}$ e presença de Fe dissociado.

2- Análise química quantitativa pontual. O pico de Si é ligeiramente mais intenso que o $\mathrm{Al}$, que aliada a morfologia sugere a ocorrência de caolinita. 
Glasmann \& Simonson (1985) citam que a alteração dos piroxênios geralmente resulta na completa destruição do cristal gerando principalmente a formação de esmectitas ou pseudomorfos de goethitas.

Os piroxênios dos riodacitos da topossequência em estudo, juntamente com os plagioclásios e em proporções quase que idênticas perfazem quase a totalidade dos fenocristais da rocha porfirítica.

De acordo com a bibliografia, os piroxênios são representados principalmente por augita (aqueles ricos em cálcio) e pigeonita (piroxênios pobres em cálcio).

A augita ocorre sob a forma de cristais subhedrais, prismáticos ou anhedrais granulares e é considerado o mineral mais freqüente, apresentando a seguinte composição química: $(\mathrm{Ca}, \mathrm{Na})(\mathrm{Mg}, \mathrm{F}, \mathrm{Al})(\mathrm{SiAl})_{2} \mathrm{O}_{6}$.

As análises feitas ao microscópio óptico levantaram a possibilidade dos piroxênios se alterarem em várias fases, resultando vários minerais secundários e vários produtos de alteração.

Durante a primeira fase, a alteração progride ao longo de um sistema de clivagens e fraturas dos piroxênios. Em seguida, aparece ao seu redor uma coroa de alteração de coloração amarelada que envolve todo o cristal. As bordas do cristal de piroxênio contornam as fissuras e os planos de clivagens internas e se degradam em óxidos de ferro se destacando também pela alta birrefringência (fotomicrografia 8).

$\mathrm{Na}$ segunda fase, as fraturas ou fissuras se tornam cada vez mais espessas e avermelhadas pela transformação em óxidos de ferro.

Nesta mesma fase, ocorrem alguns elementos, menos solúveis e menos móveis, essencialmente o ferro e o alumínio que participam da formação da estrutura do mineral em compartimentos fechados constituindo a estrutura em "Boxwork". Através da microscopia eletrônica de varredura observou que nestas estruturas em "Boxwork" levantou-se a possibilidade de que a principal característica da evolução intempérica do piroxênio seja sua transformação em hematita (fotomicrografia 9).

Na terceira fase, ocorre a alteração completa do mineral primário através das clivagens. Estas clivagens se alargam e dividem o cristal do piroxênio. 


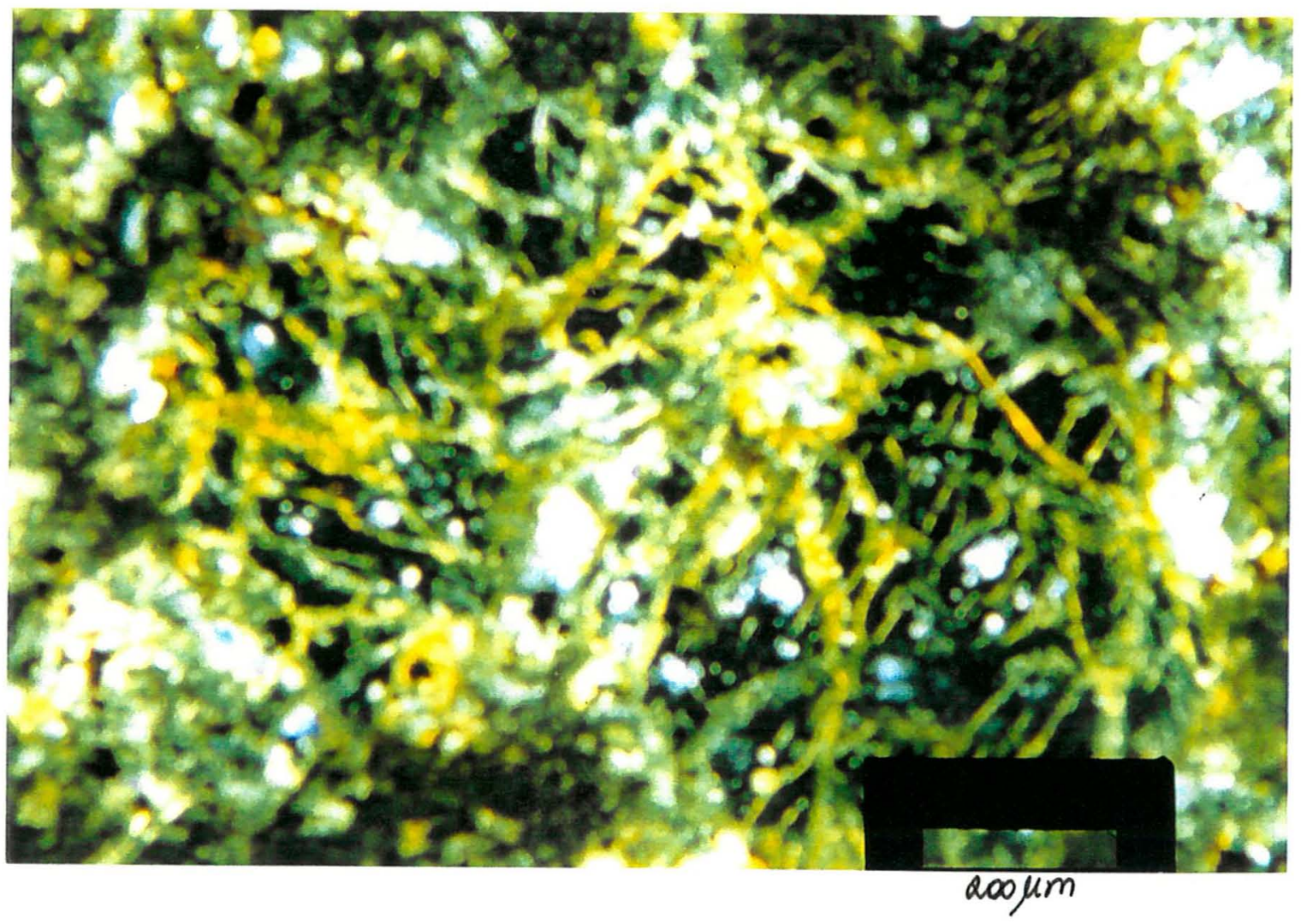

Fotomicrografia 8 - Microscópio óptico, luz polarizada e nicóis cruzados com aumento de x 2,5. Sistemas de fraturas finas e sinuosas do piroxênio preenchidas por óxidos de ferro. Amostra do perfil P4 da camada de alteração 4.5. 

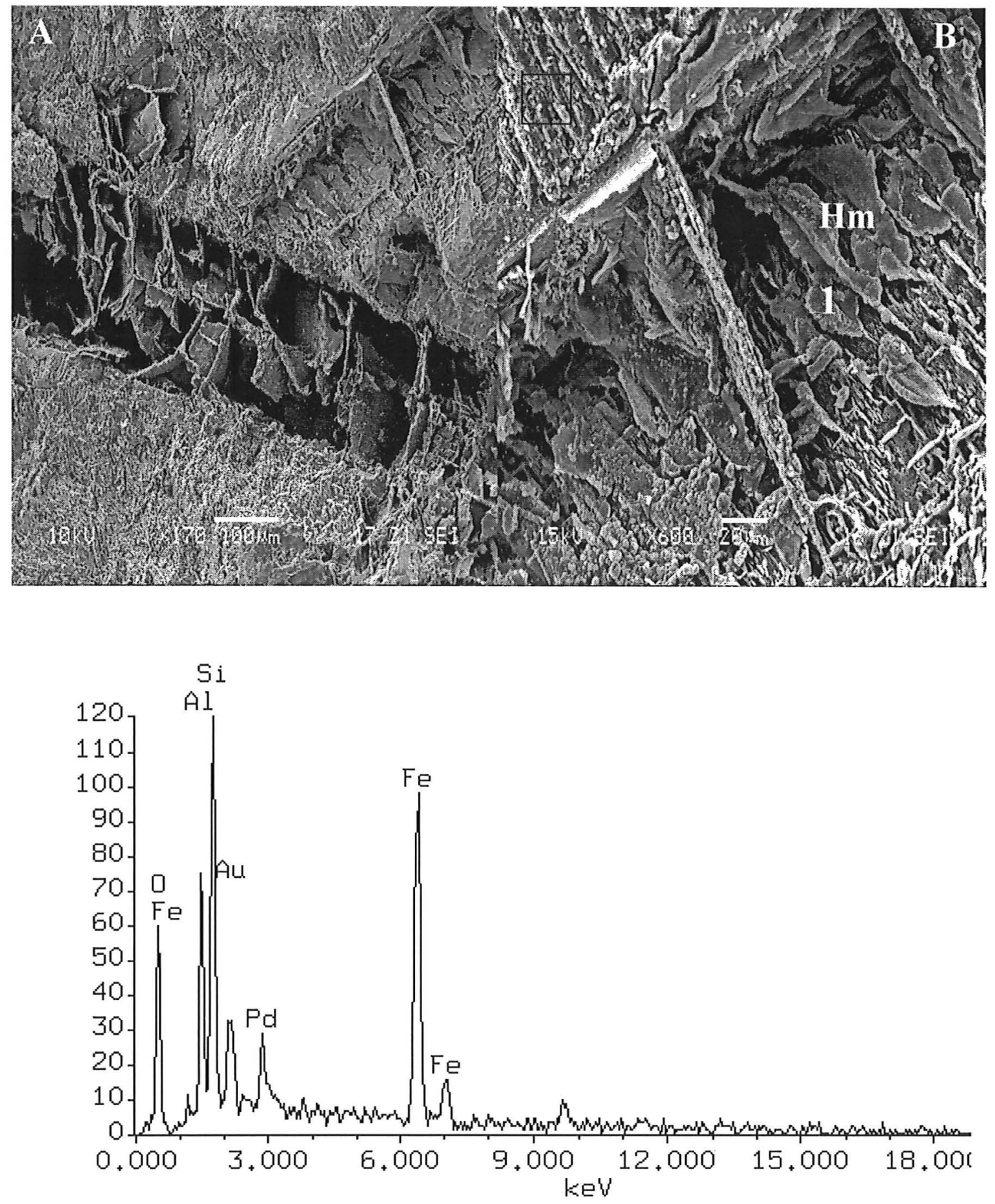

Fotomicrografia 9 - A) Análise de Microscopia Eletrônica de Varredura, apresentando estrutura em "Boxwork" do piroxênio alterado, com preenchimento por hematita (Hm); B) Detalhe maior da hematita em forma de "folha" com sua respectiva análise química qualitativa pontual no ponto 1 . 
Clemente (1988), encontrou nas estruturas de "Boxwork" as gibbsitas, que podem apresentar diversas características morfológicas e estar associada com oxihidróxidos de ferro (goethita). Essas gibbsitas que o autor citou, ocorrem em pseudomorfos de cristais alongados ou curtos de piroxênios, tendo as seguintes características:

$\Rightarrow$ gibbsitas microcristalinas, preenchendo as formas irregulares de um piroxênio.

$\Rightarrow$ gibbsitas em cristais maiores e regulares preenchendo Boxwork do cristal do piroxênio alterado.

$\Rightarrow$ gibbsitas em cristais grandes e irregulares sobre as gibbsitas de formas irregulares.

Clemente (1988), concluiu em seu estudo que a principal característica de evolução do piroxênio é sua transformação em goethita, isto é, aliado a dados obtidos pela microscopia óptica.

Contudo, além da transformação piroxênio $\Leftrightarrow$ goethita observado no trabalho, ocorre uma outra fase distinta, ou seja, a sequência piroxênio $\Rightarrow$ esmectita + goethita de acordo com Clemente (1988).

Aliada a esta evolução as pseudomorfoses podem apresentar o preenchimento de seus vazios por $\mathrm{Al}$ (gibbsita) resultando as seqüências:

Piroxênio $\Rightarrow$ esmectita e goethita

Piroxênio $\Leftrightarrow$ goethita + preenchimento por gibbsita.

\subsection{3 - Alteração da matriz do riodacito.}

Amostras da matriz do riodacito foram observadas através da microscopia eletrônica de varredura.

A fotomicrografia do perfil P1 (10A) mostra a matriz do riodacito alterado, com espaços deixados pelo piroxênio alterado. Nesta matriz pode-se observar a presença de caolinita formando uma matriz de aspecto granular. 
A análise qualitativa de toda a superfície abrangida pela fotomicrografia, revelou picos intensos de alumínio e ferro e menos intensos de sílica e potássio, levandose a supor a ocorrência de gibbsita e óxidos de ferro dissociados (Figura 29).

Às vezes, a distinção entre os minerais de argila e os compostos de ferro não é nítida, possivelmente pelo recobrimento parcial promovido pelos óxidos (Greenland et al., 1968).

A fotomicrografia do perfil P2 (10B) também do riodacito mostra alteração de um cristal de plagioclásio com sua clivagem bem nítida e ao lado uma vesícula preenchida por zeólita (mostrada na fotomicrografia 1). A análise química qualitativa de toda a superfície indicou a presença de um pico mais intenso de $\mathrm{Si}$ em relação ao $\mathrm{Al}$ e outros elementos de menor importância (Figura 29).

$\mathrm{Na}$ fotomicrografia do perfil P3 (10C) apresenta cristais de plagioclásio alterados juntamente com a matriz de aspecto granular. De acordo com a análise química qualitativa de toda a amostra observou picos intensos de $\mathrm{Al}$ e Si predominando sobre o pico menos intenso de Fe levando-se a supor a presença de caolinita (figura 29).

A fotomicrografia do perfil P4 (10D) apresenta a alteração do plagioclásio em forma de "sanfona", sempre associada com a matriz caolinítica.

Quanto a fotomicrografia do perfil P5 (10E) nota-se o espaço deixado pelo plagioclásio alterado, formas arredondadas provavelmente de goethitas dispersas por toda a matriz.

Depois de analisada toda a matriz do riodacito, da topossequência em estudo, através da análise química qualitativa, podemos observar que existe duas feições morfológicas distintas:

- uma onde os picos de $\mathrm{Al}$ e $\mathrm{Si}$ com suas intensidade equivalentes predominando sobre o $\mathrm{Fe}$, levando a supor a ocorrência de caolinitas.

- e outra onde o pico de $\mathrm{Al}$ e Fe são mais intenso levando supor a ocorrência de gibbsitas e óxidos de ferro dissociados.

Um fato não muito comum na matriz do riodacito é a presença de haloisitas. 


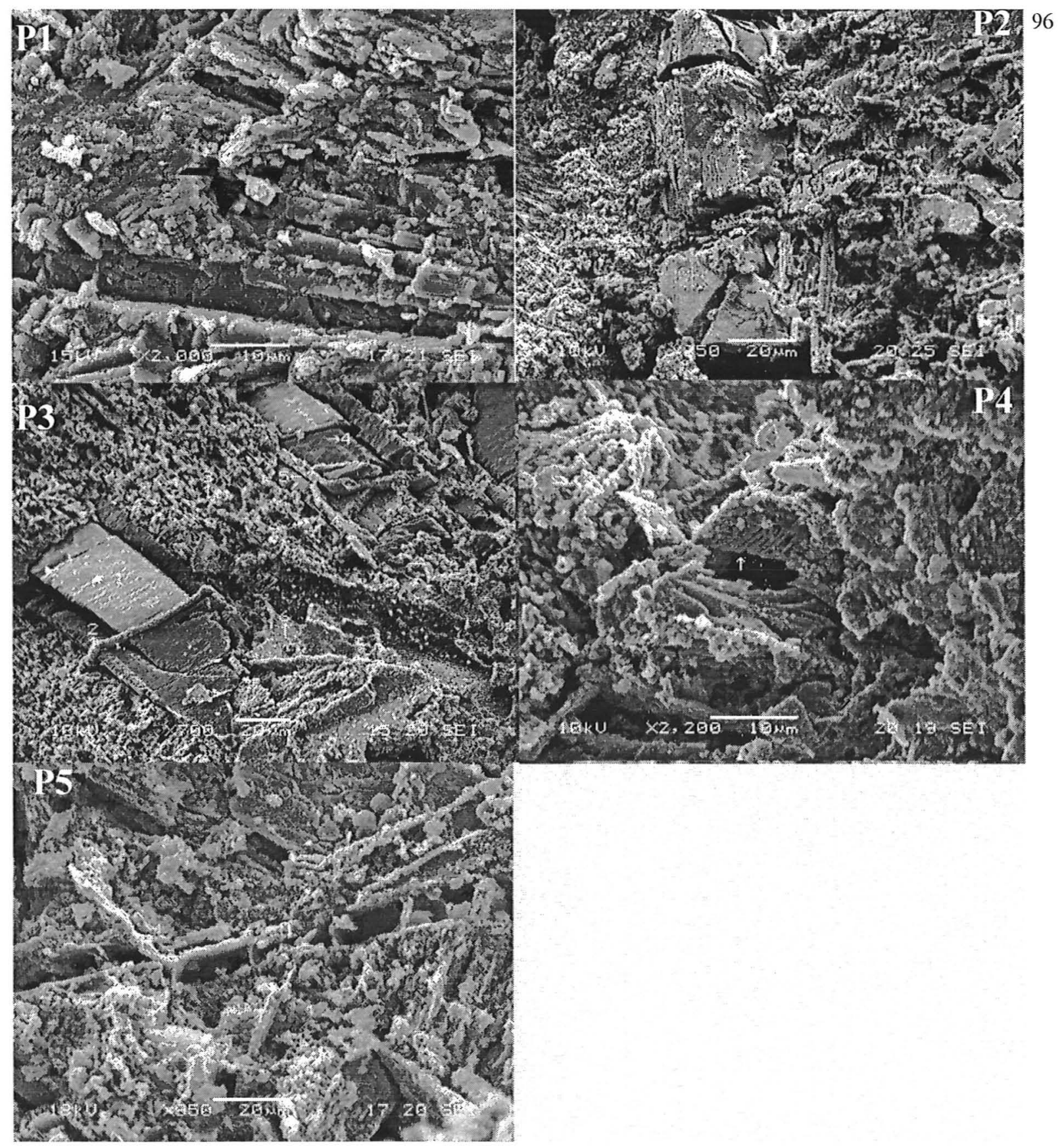

Fotomicrografia 10 - Análise por Microscopia Eletrônica de Varredura, mostrando detalhes da matriz do riodacito correspondentes aos perfis $\mathrm{P} 1, \mathrm{P} 2, \mathrm{P} 3, \mathrm{P} 4$ e P5, com suas respectivas análises químicas qualitativas totais. 

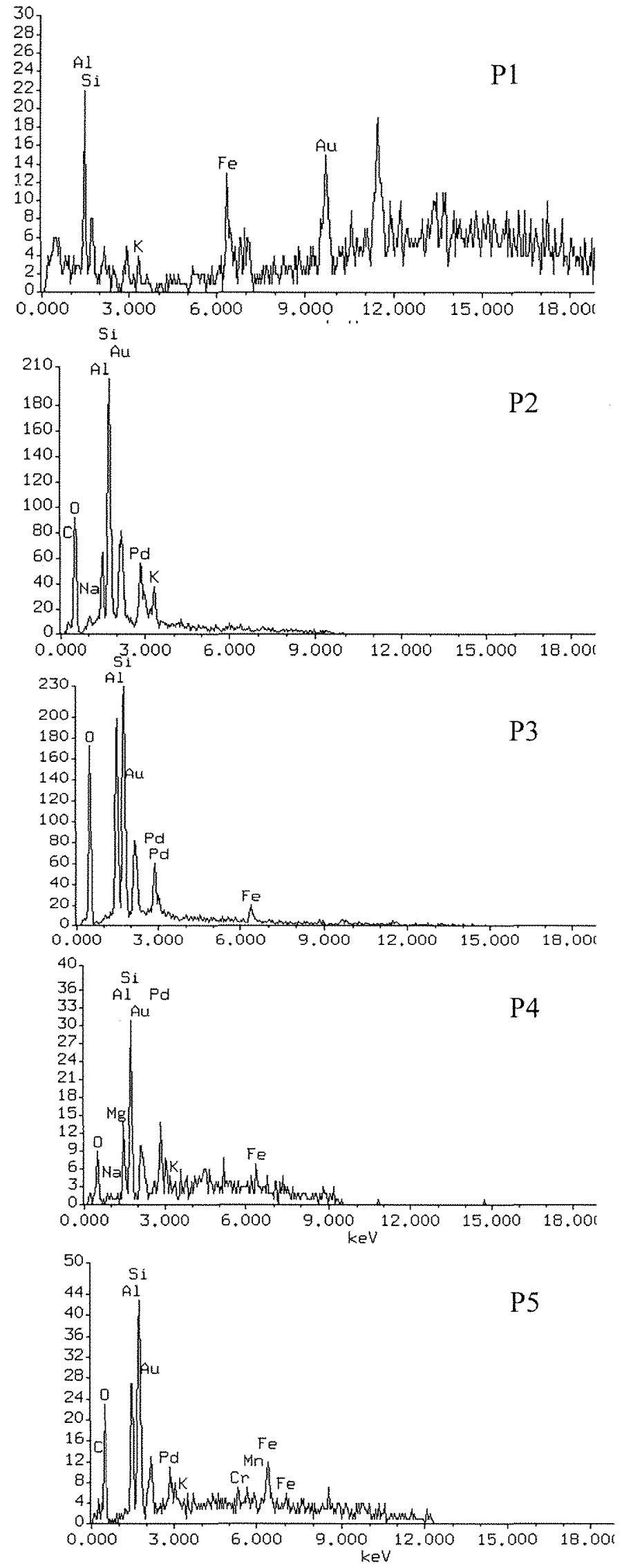

Figura 29 -Análise química global de toda a área da matriz do riodacito correspondente aos perfis P1, P2, P3, P4 e P5. 
De acordo com FitzPatrick (1993), as haloisitas ocorrem como partículas tubulares muito pequenas formando uma massa irregular. Na rocha, este mineral ocorre associado com a caolinita, gibbsita e outros materiais como resultado de alteração hidrotermal. Nos solos, elas geralmente ocorrem como produto de alteração dos plagioclásios e podem fazer parte da matriz de muitos solos.

A respeito do mecanismo envolvendo a formação de haloisitas, o que pode ser observado na microscopia eletrônica é que o intemperismo dos cristais de plagioclásio são transformados diretamente para haloisita. Esta massa de minerais é composta por uma densa aglomeração de haloisitas tubulares. A análise química qualitativa mostra ser mesmo a haloisita, pois apresenta picos intensos de $\mathrm{Al}$ e Si. (fotomicrografia 11, amostra da alteração 5.2).

Além das haloisitas, podemos encontrar também goethitas na matriz da rocha alterada, como citado anteriormente elas preenchem a superfície das cavidades deixadas pela alteração dos plagioclásios.

Nas imagens fornecidas pela microscopia eletrônica podemos observar algumas formas de goethitas: formas de "cacho de uva" e de "casa de abelha", além do hábito mamelonar já mostrado (fotomicrografia 12).

A análise feita nestes pequenos cristais, revelaram a predominância marcante do Fe confirmando ser mesmo a goethita.

\subsection{Evidências micromorfológicas}

As questões e hipóteses levantadas e argumentadas nos itens anteriores foram posteriormente investigadas através da análise micromorfológica de amostras indeformadas e coletadas nos diferentes horizontes de cada perfil. A figura 30 apresenta as posições de coleta das amostras. 


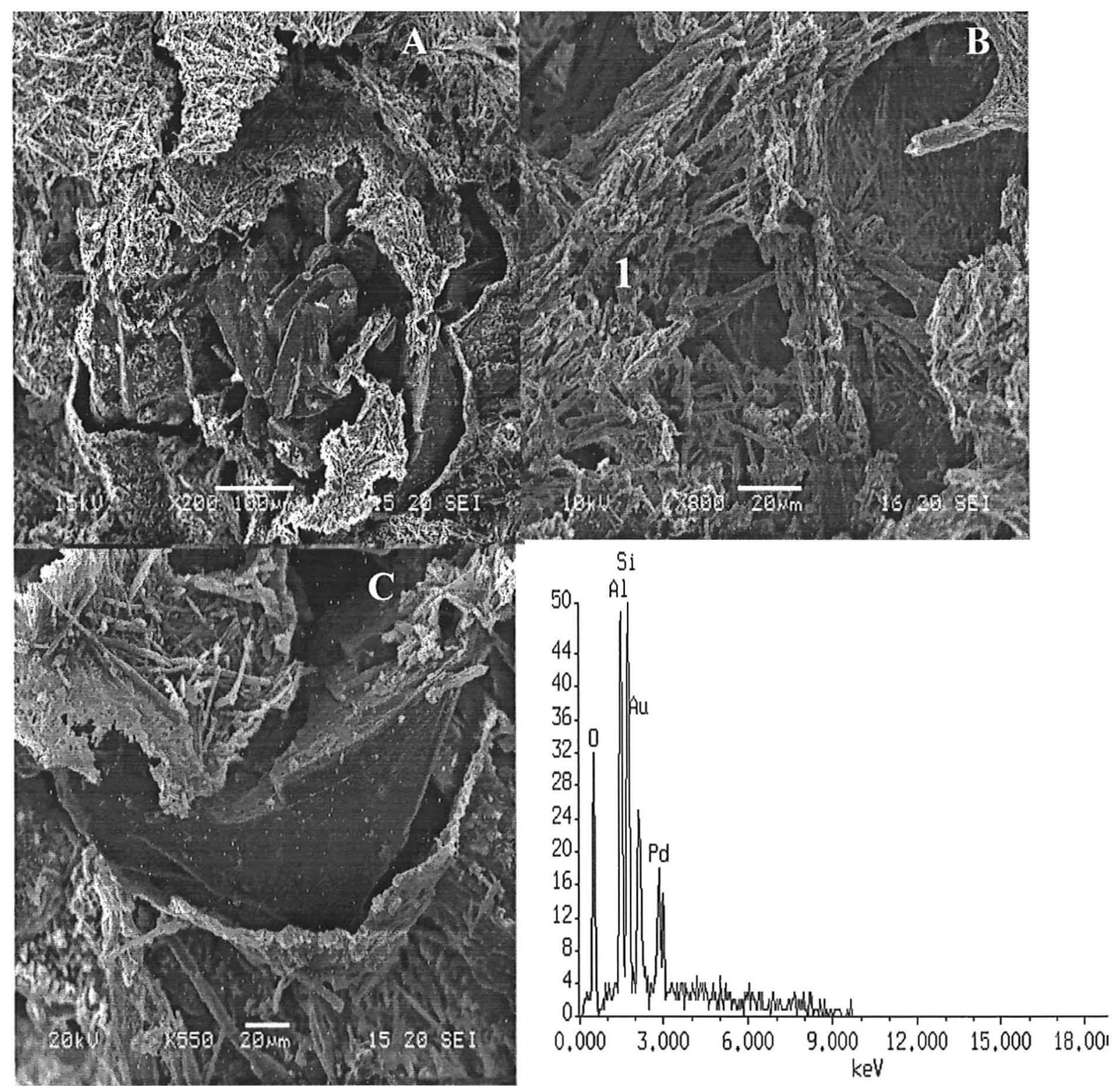

Fotomicrografia 11 - Análise por Microscopia Eletrônica. Haloisitas de hábito acicular presentes na matriz do riodacito. Nas figuras A e C observa o plagioclásio alterando para haloisita (amostra de alteração 5.2). O ponto 1 refere-se a análise química qualitativa pontual da amostra. 


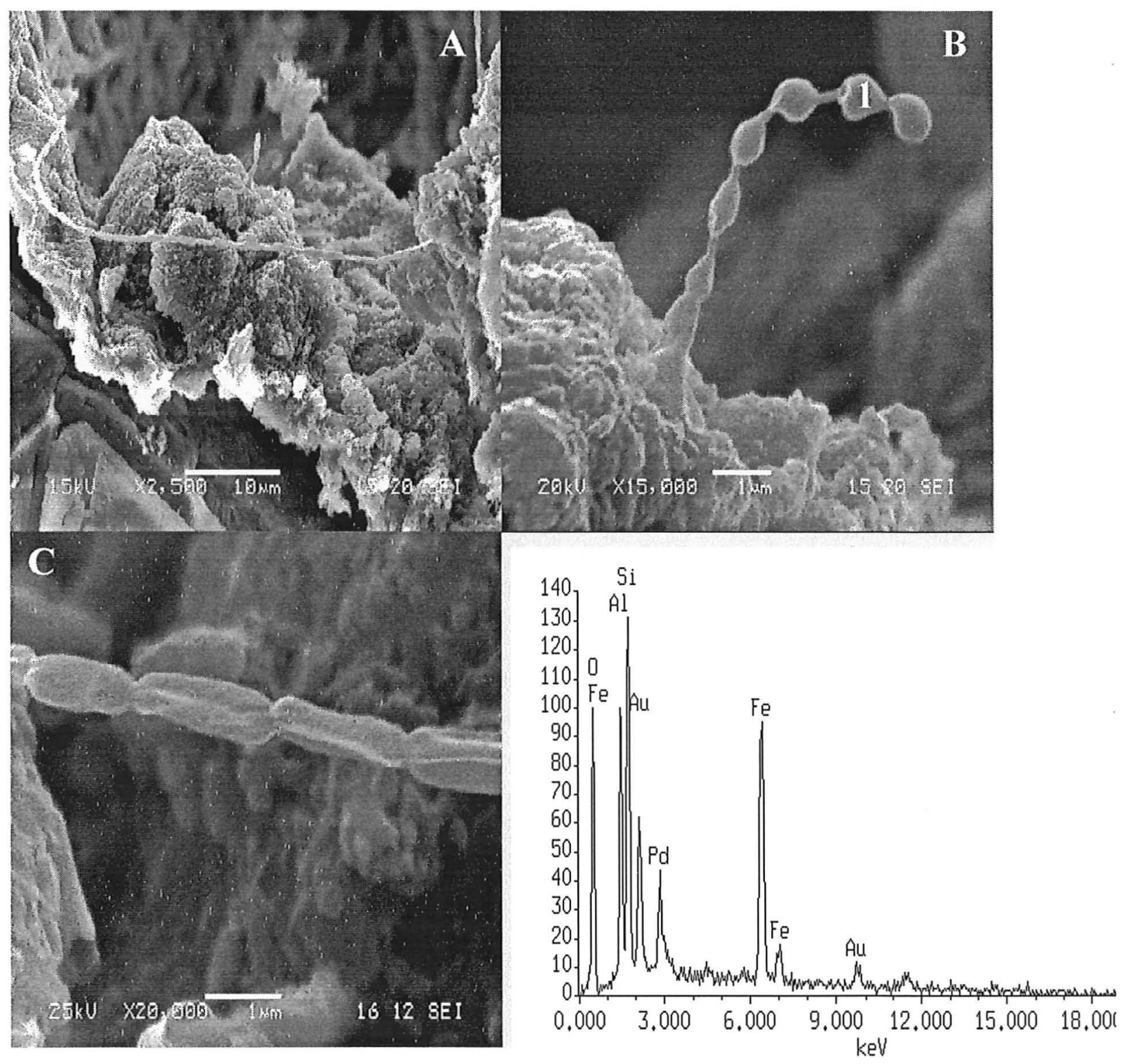

Fotomicrografia 12 - Análise por Microscopia Eletrônica. Goethitas com forma de "cacho de uva" encontrada na matriz do riodacito. O ponto 1 refere-se a análise química qualitativa pontual da amostra. 

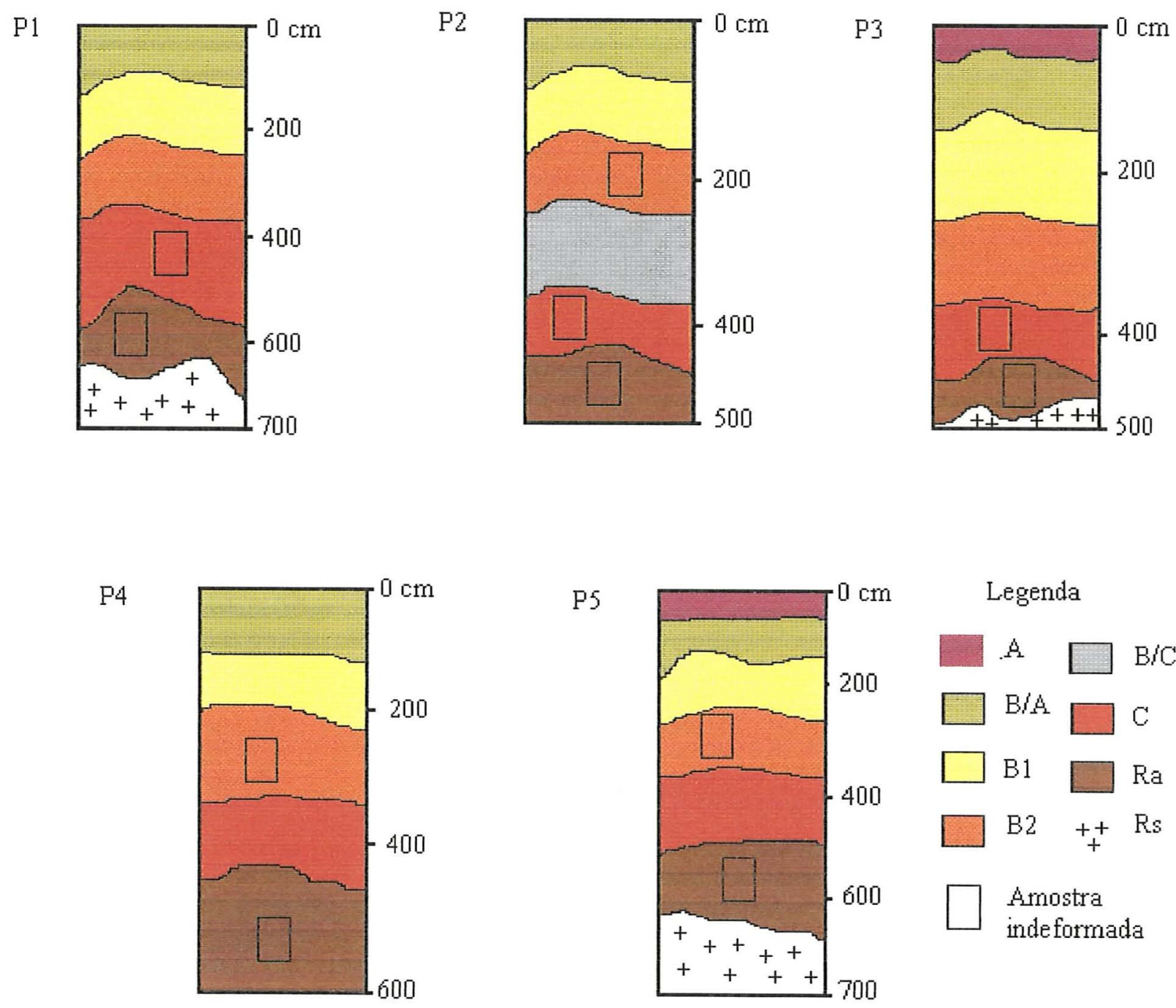

Legenda

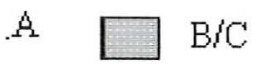

$\mathrm{B} / \mathrm{A}$

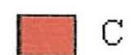

B1 $\square \mathrm{Ra}$

$\mathrm{B} 2+{ }_{+}^{+} \mathrm{Rs}$

Amostra

inde formada

Figura 30 - Esquema de disposição dos horizontes e localização de coletas das amostras indeformadas nos perfis. 
A descrição micromorfológica apresentada a seguir nada mais é do que um apanhado geral de todos os perfis da topossequência estudada, seguindo Brewer (1964).

Matriz do solo: das lâminas analisadas pode-se observar dois tipos de plasma:

1) um plasma de coloração marrom avermelhado, argilo-ferruginoso, sem orientação, isto é, de estrutura asépica de domínios identificáveis, não orientados entre si (argila sépica). Este plasma corresponde aos perfis P1, P2 e P3.

2) Os perfis P4 e P5 apresentam um plasma de coloração alaranjada, rico em separações plásmicas (estrutura masépica), isto é, estriações paralelas ao alongamento das zonas, em uma ou várias direções, ou envolvendo grãos do esqueleto e vazios, em estrutura do tipo vo-esquel-masépica (vosépica - ligada aos vazios e esquelsépica - ligada ao esqueleto).

O fundo matricial constitui-se de um esqueleto granular fino, composto por grãos de quartzo, plagioclásios e opacos, esparso no argiloplasma (distribuição relativa do esqueleto em relação ao plasma, sendo, do tipo porfirosquélica), isto é, grãos isolados dentro do plasma quase contínuo, ou isolados e flutuantes no sistema de vazios, com pouca tendência ao desenvolvimento de microestrutura.

Ferreira et al. (1999) classifica essa pouca tendência ao desenvolvimento de microestrutura devido ao ajuste face a face das placas de caolinita, implicando no desenvolvimento de macroestrutura do tipo em blocos, devendo originar Latossolos com maior densidade do solo, maior proporção de poros pequenos e menor permeabilidade.

Esqueleto: constituído quase que exclusivamente por microcristais de quartzo, em geral arredondados a subarredondados, alguns apresentam-se corroídos com impregnações ferruginosas.

Presença em menor quantidade de grânulos de plagioclásio, de tamanho variando de micro a macrocristais, suas formas em geral são angulosas, sendo também corroídas e preenchidas por outros materiais. 
Os grãos de opacos se apresentam individualizados ou fragmentados no plasma contínuo.

Feições Pedológicas: nódulos de ferro (hematita, goethita) bastante comum, poucas concentrações em forma circular, com orientação fraca e moderada disseminada no plasma.

Ausência de cutãns em todos os perfis.

Poros: foram classificados como predominantemente fissurais (cerca de 60\%) e na forma de cavidades (cerca de 40\%), apresentando formas irregulares $(60 \%)$ e mamelonados $(40 \%)$.

Os dados micromorfológicos da topossequência estudada, assim como os resultados das diversas fases de alteração das rochas podem fornecer uma história de formação dos solos.

A formação da caolinita, na primeira fase de alteração dos plagioclásios leva a sugerir um ambiente de intemperismo não muito intenso. Em termos de processo, poderia ser enquadrado como uma monossialitização (hidrólise parcial). 


\section{CONCLUSÃO}

Os resultados obtidos, suas considerações e interpretações permitiram as seguintes conclusões:

1 - A rocha ácida é caracterizada pela presença de fenocristais de plagioclásio, piroxênio e microfenocristais de magnetita.

2 - Através das análises por difratometria de raios-X, observou-se que a mineralogia da fração argila é bastante simples sendo composta por caolinita (dominante), gibbsita, mica, esmectita, vermiculita e haloisita.

$\mathrm{Na}$ fração silte e areia a similaridade mineralógica é bastante comum, podendo citar: quartzo, feldspato, plagioclásio, piroxênio e a magnetita, sendo que, na fração areia os piroxênios e a magnetita estão ausentes evidenciando sua degradação.

3 - A alteração dos plagioclásios procede seguindo várias linhas evolutivas principais, ou seja:

a) nos cristais onde a evolução é praticamente direta para caolinita, levando a sugerir um processo de intemperismo não muito intenso, isto é, processo de hidrólise parcial (monossialitização).

b) nos cristais onde a evolução é para gibbsita, levando a sugerir um processo de intemperismo muito intenso, onde o que predomina é a alitização (hidrólise total).

c) nos cristais de plagioclásio onde a evolução é para mica e haloisita, onde o que predomina é o processo de hidrólise parcial. 
É comum nas alterações dos plagioclásios encontrar cristais de goethita que se formam nas paredes de dissolução do mineral.

Esses resultados são semelhantes aos encontrados por Clemente (1988), onde seguem 3 linhas evolutivas principais, ou seja:

$$
\begin{aligned}
& \text { plagioclásio } \Rightarrow \text { gibbsita } \\
& \text { plagioclásio } \Rightarrow \text { geles } \Rightarrow \text { gibbsita } \\
& \text { plagioclásio } \Rightarrow \text { geles } \rightarrow \text { gibbsita }+ \text { caolinita }
\end{aligned}
$$

o que leva a sugerir um ambiente de intemperismo muito intenso. Em termos de processos, poderia ser enquadrado como uma alitização (hidrólise total).

4 - Quanto aos piroxênios, estes apresentam uma linha evolutiva principal:

a) a principal característica de alteração do piroxênio é a formação de estruturas porosas ("Boxwork") com preenchimento de hematitas e goethitas ao longo de seu sistema de clivagem e fratura.

Estes dados também se assemelham aos fornecidos por Clemente (1988), onde apresentam também 3 linhas evolutivas principais:

$$
\begin{aligned}
& \text { piroxênio } \Rightarrow \text { goethita } \\
& \text { piroxênio } \Rightarrow \text { esmectita e goethita } \\
& \text { piroxênio } \Rightarrow \text { goethita }+ \text { preenchimento de suas estruturas porosas }
\end{aligned}
$$
("Boxworks") por $\mathrm{Al}$ formando a gibbsita.

5 - A evolução da matriz do riodacito é: matriz $\Rightarrow$ caolinita + óxidos e hidróxidos de Fe.

6 - Aliando-se aos fenômenos de alteração dos plagioclásios $\rightarrow$ caolinita, e as condições climáticas da região pode-se dizer que o fenômeno de alteração predominante é a monossialitização. 
7 - A análise micromorfológica identificou dois tipos de plasma: a) de coloração marrom - avermelhado sem orientação, isto é, de estrutura asépica de domínios identificáveis, não orientados entre si (argila sépica); b) outro como um plasma de coloração alaranjado, rico em separações plásmicas (estrutura masépica), isto é, estriações paralelas ao alongamento das zonas, em uma ou várias direções, ou envolvendo grãos do esqueleto e vazios, em estrutura do tipo vo-esquel-masépica. 


\section{REFERÊNCIAS BIBLIOGRÁFICAS}

ABREU \& ABREU. A extração com DTPA: Determinação de cobre, ferro, manganês e zinco em solos. Campinas: IAC- Instituto Agronômico de Campinas. 1996. p.9

ALMEIDA, F.F.M., Síntese sobre a tectônica da Bacia do Paraná. Atlas do III Simpósio Regional de Geologia, São Paulo, SP. 1981.

BELLIENI, G.; COMIN - CHIARAMONTI, P.; MARQUES, L. S.; MARTINEZ, L. A, MELFI, A. J.; NARDY A J.; PICCIRILlO, E; . and STOLFA, D., Continental flood basalts from the central-western regions of the Paraná plateau (Paraguay and Argentina): petrology and petrogenetic aspects. Neues Jahr. Miner. Abh., 1986 a. v. 154, p 111-139.

BELliENI, G.; COMIN - CHIARAMONTI, P.; MARQUES, L. S.; MELFI, A. J.; NARDY A .J.R.; PAPATRECHAS C., PICCIRILlO, E. M., ROISENBERG, A. and STOLFA, D., Petrogenetic aspects of acid and basaltic lavas from the Paraná plateau (Brazil): geological, mineralogical and petrochemical relationships. Journal of petrology, 1986b. v. 27 , p. 915-944.

BONIFAS, M. Contribuition á l' etude geochimique de l'alteration lateritique. Mém. Serv. Cart. Geol. Als. Lon., (17): 153p. Paris 1959.

BOULANG, G.- Les formations bauxitiques lateritiques de Côte - D' ivoire. Mén. Orstom, Paris 1984. v.175, p.363.

BOUABID, R.; NATER, E A. BLOOM, P. R. Characterization of the weathering status of feldspar minerals in sandy soils of Minnesota using SEM and EDX. Geoderma, v.66, n. 1-2, p.137-149, Apr. 1995. 
BREWER, R. Fabric and mineral analysis of soils. New York: Robert E. Krieger Publishing Company, 1976. 482 p.

BRINDLEY, G. W. Terminology of the clay minerals. Madrid, 1966-1967.p. 6 - 10 .

BROWN, G. (Ed.) The x-ray identification and crystal structures of clay minerals. London: Mineralogical Society, 1961. 544 p.

BROWN, G. \& BRINDLEY, G. W. X-ray diffraction procedures for clay mineral identification. In: BRINDLEY, G. W; BROWN, G. Crystal structures of clay minerals and their X-ray identification. London: Mineralogical Society, 1980. p. 305-360.

BULLOCK, P.; FEDOROFF, N.; JONGERIUS, A.; STOOPS, G.;TURSINA, T.; BABEL, U. Handbook for soil thin section description. England: Waine Research Publications Wolverhampton, 1985. $153 \mathrm{p}$.

CAMARGO, O.A.; MONIZ, A.C.; JORGE, J. A.; VALADARES, J. M. Métodos de análise química, mineralógica e física de solos do IAC. Campinas: IAC, 1986. p.94. (Boletim técnico $\left.{ }^{0} 106\right)$.

CASTRO, S.S. Impregnação de amostras de solo para confeç̧ão de lâminas delgadas. Boletim informativo/S.B.C.S. Campinas. 1985.

CASTRO, S.S. Micromorfologia de solos - Pequeno guia para descrição de lâminas delgadas. Departamento de Geografia. USP-IPT-DMGA. São Paulo. 1989, 87 p.

CERRI, C.C. Alteração e Pedogênese em áreas graníticas situadas sob diferentes condições bioclimáticas encontradas no Brasil. São Paulo, 1979. 241p. Tese (Doutorado) - Instituto de Geociências da Universidade de São Paulo. 
COMIN - CHIARAMONTI, P; BELliENI, G; .; PICCIRILlO, E; MELFI, A. J.Classification and Petrography of continental stratoid volcanics and related intrusives from the Paraná Basin (Brazil). 1988.

CLEMENTE, C. A. Alterações e solos desenvolvidos sobre rochas vulcânicas ácidas da Formação Serra Geral nos Planaltos de Guarapuava e Palmas, região centro-sul do Estado do Paraná.. 1988. 211p.Tese (Doutorado) - ESALQ/USP.

DANA, J.D. Manual de mineralogia. 1978. Livros técnicos e científicos. ed. s.a.643p.

DELVIGNE, J. Pedogénese en zone tropicale. La formation des mineraux secondaires en milieu ferrallitique, Mén. Orstom, 13, 1965. 177p., Dunod Paris.

DIXON, J.B. Quantitative analysis of Kaolinite and gibbsite in soils by differential thermal and selective dissolution methods. In: CLAYS AND CLAYS MINERALS CONFERENCE, 14, Proceedings. New York, Pergamon Press, 1966. p. 82-89.

DOUGLAS, L.A . Vermiculites. In: DIXON, J.B.; WEED, S.B. (Eds.). Minerals in soil environments. Madison: SSSA Books Series n.1, 1989, chap.13, p.635-674.

EMPRESA BRASILEIRA DE PESQUISA AGROPECUÁRIA. Manual de métodos de análise de solos. $2^{\mathrm{a}}$ edição. Rio de Janeiro: EMBRAPA/CNPS, 1997. 212p.

EMPRESA BRASILEIRA DE PESQUISA AGROPECUÁRIA. Centro Nacional de Pesquisa de Solos. Sistema brasileiro de classificação de solos. Brasilia: EMBRAPA, Produção de Informação; R. J. EMBRAPA, Centro Nacional de Pesquisa de Solos, 1999. 412p.

ESWARAN, H.; SYS, C. Argillic horizon in LAC soils: formation and significance to classification. Pedologie, Ghent, 1979. v.29, p.175-190. 
FERREIRA, M. M., FERNANDES, B., CURI, N. Mineralogia da fração argila e estrutura de latossolos da região sudeste do Brasil. Revista Brasileira de Ciência Do Solo, Campinas, v.23 (3): $507-514,1999$.

FITZPATRICK, E.A. Soil Microscopy and Micromorphology. 1993. 304p.

FÚlfaro, V.J. \& SUGUIO, K., Campos de diques de diabásio da Bacia do Paraná. Bol. Soc. Bras. Geol., 1967. V.16, 23-37.

FÚlFARO, V.J. \& SUGUIO, K., Geologia da região de Fartura - SP. Anais do XXVIII Congresso Brasileiro de Geologia, 1974. p.173-180.

FÚLFARO, V.J., Tectônica do alinhamento estrutural do Paranapanema. Bol. Inst. Geoc., USP, 1974. v.5, 129-138.

FÚLFARO, V.J., SAAD, A. R. \& VIANNA, R.B., Compartimentação tectônica da Bacia do Paraná. Revista Brasileira de Geociências, 1982. v.12, 590-611.

GASPARETTO, N. V. L., Alteração intempérica de rochas vulcânicas ácidas na Região Central do Estado do Rio Grande do Sul, Brasil. 1990. Dissertação (M.S.) - Instituto de Geociências - USP. São Paulo.

GOMES, B. C., Técnicas analíticas instrumentais aplicadas à geologia. São Paulo: ed. Blucher, 1984. 218p.

GONÇALVES, N.M.M., Transformações mineralógicas e estruturais relacionadas à alteração hidrotermal e intempérica de rochas vulcânicas básicas da Bacia do Paraná Setentrional - Região de Ribeirão Preto - SP. Brasil. 1987. 212p. Tese (Doutorado) - Instituto de Geociências - USP. São Paulo.

GLASMANN, J. R. \& SIMONSON, G.H. Alteration of basalt in soils of Western Oregon. Soil Sci. Soc. Am. J., Jan./ Feb. 1985. v.49, n.1, p. 262-273. 
GRIFFIN, G. M. Interatin of x-ray diffraction data. In: CAVER, ROBERT E. (Ed.) Procedures in sedimentary petrology. New York: Wiley-interscince, 1971. Cap. 24, p. 541-569: Interatin of x-ray diffraction data.

GRIM, R.E. Clay mineralogy. 2.ed. New York: Mc-Graw-Hill, 1968. 596p.

HANRION, C., Techniques utilisees pour la preparation des lames minces petrographiques. ORSTOM Centre D'Adiopodoume. Côte D'Ivoire. Abidjan. 1976.39p.

HYPOLITO. R., Estudo experimental de alteração intempérica de diabásio. 1972. Tese (Doutorado) - Instituto de Geociências - USP. São Paulo.

INSKEEP, W. P.; CLAYTON, J.L.; MOGK, D.W. Naturally weathered plagioclase grains from Idaho batholith: observations using scanning electron microscopy. Soil Sci. Soc. Am. J., May/Jun. 1993. v.57, n.3, p.851-860.

IYOMASA, W. S., As rochas vulcânicas ácidas da Formação Serra Geral no vale do rio Paranapanema (SP/PR). $\mathbf{3 8}^{0}$ Congresso Brasileiro de Geologia - Balneário Camboriú - SC. 1994. p.107-108.

JACKSON, M. L. Soil chemical analysis advanced course. $2^{\text {nd }}$ ed. Madson, Wisconsim: University of Wisconsin - Departament of soil Science, 1969. 895p.

KÄMPF, N. Hàloisitas em saprolitos de rochas vulcânicas do Rio Grande do Sul. Revista Brasileira de Ciência Do Solo, Campinas, v.19 (2): 179 - 184, 1995. KRETZSCHMAR, R.; ROBARGE, W.P.; AMOOZEGAR, A ; VEPRASKAS, M.J. Biotite alteration to halloysite and kaolinite in soil-saprolite profiles developed from mica schist and genesis. Geoderma, v.75, nos 3-4, p.155-170, Feb. 1996. 
LEINZ, V. Contribuição à geologia dos derrames basalticos do Sul do Brasil. Bol. Fac. Cienc. Lt. USP, 103p. 1949.

LEMOS, R.C. \& SANTOS, R .D. Manual de método de trabalho de campo. 3.ed. Campinas: Sociedade Brasileira de Ciência do Solo, 1996. 83p.

LEVI, F. \& MELFI, A. J. Geochimical and Mineralogical studies on the first stage of weathering of basic and related roks. Part 2. Geochemical Study. Rev. Bras. Geoc. 2(1): 1-7. 1972.

MELFI, A. J. Intemperismo de granitos e diabásios do município de Campinas e arredores 1967. 166p. Tese (Doutorado) - ESP. São Paulo.

MELFI, A. J. \& LEVI, F. Geochimical and Mineralogical study on the first stage of weathering of basic and related roks. Part 1. Mineralogical Study. Rev. Bras. Geoc. 1(1): 22-28. 1971.

MENEGOTTO, E. Alteração intempérica das rochas básicas faneríticas de Pedras Pretas, São Sepé (RS). 1996.

MENEGOTTO, E. \& GASPARETTO, N.V.L. Intemperiza ção de rochas vulcânicas básicas e ácidas na região de Santa Maria - RS. Anais 10 Cong. Bras. Geog. 1987. v. $2,69-23$.

MING, D. W. \& MUMPTON, F. A. Zeolites in sois. In: DIXON, J. B. \& WEED, S. B., eds. Minerals in Soil Environments. 2.Ed. Madison, Soil Science Society of America, 1989. p. 873 - 911.

MINIOLI, B.; PONÇANO, W.L.; OLIVEIRA., S.M.B. de. Extensão geográfica do vulcanismo basaltico do Brasil meridional. Anais Acad. Brasil. Ciênc., 1971. v.43, 433-437. 
NARDY, A.J.R.; MARQUES, L.S. \& RAPOSO, M.I.B. Aspectos Petrológicos das rochas efusivas ácidas da Região Centro Sul do Estado do Paraná. Rev. Geociências - UNESP. 1986. v. 516: 43-57.

NARDY, A.J.R. Petrologia e Paleomagnetismo das rochas vulcânicas da Região CentroSul do Estado do Paraná: Formação Serra Geral IAG, 1987. 186p. Dissertação (M.S.).

NARDY, A.J.R. Geologia e petrologia do vulcanismo mesozoico da região central da Bacia do Paraná. 1993. Tese (Doutorado) - Universidade Estadual Paulista, Instituto de Geociências e Ciências Exatas.

NORTHFLEET, A., MEDEIROS, R. A. \& MUHLMANN, H. Reativação dos dados geológicos da Bacia do Paraná. Bol. Tec. Petrobras, Rio de Janeiro, 12, 291-346, 1969.

NOVIKOFF, A. L'alteration des roches dans le massif du chaillu (Republique Populaire du Congo). Formação et évolution des argiles en zone ferralitique. Th. Doct. Sc., Strasbourg, 297p.

OLIVEIRA, J.B. de. Classes Gerais de solos do Brasil: guia auxiliar para seu reconhecimento. 2.ed. Jaboticabal, FUNEP, 1992. 201p.

PETRI, S. \& FUlFARO, V.J., Geologia do Brasil. T. A. Queiroz. Editora da Universidade de São Paulo, 631p. 1983.

PICCIRIllo, E. M. CIVETTA, L., PETRINI, R., LONGINELli, A., COMINCHIARAMONT, P., BELLIENI, G., MARQUES, L.S. \& MELFI, A. J. Regional variations within the Paraná continental flood basalt sequences as evidence for 
different mantle regions and variable crustal contamination. Terra Cognita v: 7 , 618p. 1987.

RAPOSO, M.I.B. Evolução magmática e petrológica das rochas vulcânicas ácidas mesozóicas da Região de Piraju - Ourinhos (SP e PR) 1987.159p. - Dissertação (M.S.) - Departamento de Geofísica, Universidade de São Paulo.

ROSOLEN, V. S., Cartas pedogeoquímicas dos solos desenvolvidos sobre as rochas vulcânicas da Formação Serra Geral: utilização de um sistema de informação geográfica (SIG). 1996. 84p. Dissertação (M.S.) - Instituto de Geociências, Universidade de São Paulo.

RUEGG, N. R. Características de distribuição e teor de elementos principais em rochas basalticas da Bacia do Paraná. Bol. Inst. Geoc. USP. 1976. v. 7, 81-106.

RUEGG, N. R. \& AMARAL, G. Variação regional da composição química das rochas basálticas da Bacia do Paraná. Bol. Inst. Geoc., USP, v.7: 131-147. 1976. SARTORI, P.L.P., BORTOLOTTO, O.J.; KAWASHITA, K., Os principais tipos de rochas vulcânicas da Bacia do Paraná no Planalto de Santa Catarina - Ciência e Natura. v. $4,71-84.1982$.

SARTORI, L.L. \& MACIEL, F.C., Petrografia das regiões ácidas da Formação .Serra Geral na região do Rio Paranapanema - SP. Ciência e Natura, v. 5, 19-23. 1983.

VICTOR, E. B., RON, J. \& DEANE, K.S., Specimem preparation procedures in x-ray fluorescence analysis. In: VICTOR, E. B.; DEANE, K.S. (Ed.) A pratical guide for the preparation of specimens for $x$-ray fluorescense and $x$-ray diffraction analysis. 1998 , cap.2, p.35-43. 
ANEXOA

DESCRIÇÃO MACROMORFOLÓGICA DOS PERFIS ESTUDADOS 


\section{DESCRIÇÃO MACROMORFOLÓGICA DOS PERFIS}

A descrição macromorfológica do solo foi efetuada nos 5 perfis da topossequência Timburi, caracterizado como um LATOSSOLO VERMELHO Distrófico típico.

\section{PERFIL P1}

Horizonte BA : 0-27 cm; marrom avermelhado escuro (2,5YR 3/4), muito-argilosa, estrutura grumosa com blocos subangulares, média 3 a $8 \mathrm{~mm}$, com algumas porções um pouco maiores 1 a $2 \mathrm{~cm}$; consistência seca ligeiramente dura e friável quando úmida; plástica e pegajosa; raízes comuns e pedotúbulos com $1 \mathrm{~cm}$ de diâmetro; transição difusa e plana.

Horizonte B1 : 27 - $104 \mathrm{~cm}$; vermelho escuro (2,5YR 3/6), muito-argilosa, estrutura em blocos subangulares, pequena 0,8 a $2,5 \mathrm{~mm}$, fragmentando-se em agregados milimétricos; consistência seca ligeiramente dura e friável quando úmida; plástica e pegajosa; pedotúbulos com $1 \mathrm{~cm}$ de diâmetro; cerosidade pouco abundante; transição difusa e plana.

Horizonte B2 : $104-183 \mathrm{~cm}$; marrom avermelhado escuro (2,5YR 3/4), muitoargilosa, estrutura em blocos subangulares com 2 a $3 \mathrm{~cm}$, consistência seca ligeiramente dura e friável quando úmida; plástica e pegajosa; presença de nódulos argilosos; transição difusa e ondulada a irregular.

Horizonte CR : 183 - $380 \mathrm{~cm}$; marrom avermelhado escuro (2,5YR 3/4), muitoargilosa, estrutura em blocos subangulares com 3 a $5 \mathrm{~cm}$, fraco a medianamente desenvolvidos, consistência seca dura e firme quando úmida; não plástica e não pegajosa; presença de mosqueados de coloração acinzentada

1.3 e 1.4 : predominam cores amareladas e o material é bem mais friável. Os fenocristais de plagioclásio apresentam sinais marcantes de alteração, com coloração modificada.

1.2 : as cores são mais acinzentadas. A estrutura foi toda destruída tornando-se uma rocha muito friável. Os plagioclásios estão coloridos de tons amarelados. 


\section{PERFIL P2}

Horizonte BA : 0- $41 \mathrm{~cm}$; marrom avermelhado escuro (2,5YR 3/4), muito-argilosa estrutura grumosa, com 2 a $5 \mathrm{~mm}$ de diâmetro, algumas porções com blocos subangulares pouco desenvolvidos com 0,5 a $1,5 \mathrm{~cm}$ de diâmetro; consistência seca ligeiramente dura e friável quando úmida; plástica e pegajosa; raízes finas e abundantes; transição difusa e plana.

Horizonte B1 : 41 - $137 \mathrm{~cm}$; vermelho (2,5YR 4/6), muito-argilosa; estrutura em blocos subangulares, grandes, 4 a $12 \mathrm{~cm}$, pouco desenvolvidos; consistência seca ligeiramente dura e friável quando úmida; plástica e pegajosa; pedotúbulos com $1 \mathrm{~cm}$ de diâmetro; cerosidade comum; transição difusa e plana.

Horizonte B2 : 137 - $295 \mathrm{~cm}$; marrom avermelhado (2,5YR 4/4), muito-argilosa, estrutura blocos subangulares pouco desenvolvidos, 3 a $7 \mathrm{~cm}$; consistência seca ligeiramente dura e friável quando úmida; plástica e pegajosa; cerosidade pouco comum, presença de nódulos argilosos e nódulos de ferruginosos.

Horizonte BC : 295 - $430 \mathrm{~cm}$; marrom avermelhado (2,5YR 4/4), muito-argilosa, estrutura blocos subangulares pouco desenvolvidos, consistência seca dura e firme quando úmida; plástica e pegajosa; cerosidade pouco comum, presença de nódulos argilosos e nódulos de ferruginosos e . cristais de quartzo

Horizonte C : $+430 \mathrm{~cm}$; marrom avermelhado (2,5YR 4/4), muito-argilosa, estrutura maciça, com volumes centimétricos de saprolito vermelho rosado a cinza amarelado, consistência seca extremamente dura e extremamente firme quando úmida; não plástica e não pegajosa; presença de alguns nódulos argilosos e ferruginosos.

2.4 : os plagioclásios já se encontram com uma coloração mais alaranjada, essa camadas exibem coloração arroxeada.

2.3: os fenocristais de plagioclásio já apresentam sinais marcantes de alteração, as camadas exibem coloração arroxeada. 


\section{PERFIL 3}

Horizonte A: $0-27 \mathrm{~cm}$; marrom avermelhado escuro (2,5YR 3/4), muito-argilosa, estrutura grumosa, média, $2-3 \mathrm{~mm}$; consistência seca ligeiramente dura e friável quando úmida; plástica e pegajosa; raízes finas muito abundantes; transição difusa e ondulada.

Horizonte BA: 27 - $88 \mathrm{~cm}$; vermelho escuro (2,5YR 3/6), muito-argilosa, estrutura em blocos subangulares pouco desenvolvidos, $1 \mathrm{a} 7 \mathrm{~cm}$; consistência seca ligeiramente dura e friável quando úmida; plástica e pegajosa; raízes comuns e abundantes, pedotúbulos preeenchidos por microagregados; transição difusa e plana.

Horizonte B1: 88 - 242cm; vermelho escuro (2,5YR 3/6), muito-argilosa; estrutura em blocos subangulares de grau pouco desenvolvidos que se desfaz em agregados subangulares ou granulares pequenos, $3-7 \mathrm{~mm}$ de diâmetro; consistência seca ligeiramente dura e friável quando úmida; plástica e pegajosa; raízes comuns; transição difusa e plana.

Horizonte B2: 242 - $345 \mathrm{~cm}$; marrom avermelhado (2,5YR 4/4), muito-argilosa, estrutura em blocos subangulares de grau pouco desenvolvidos, consistência seca ligeiramente dura e friável quando úmida; plástica e pegajosa; nódulos ferruginosos; transição gradual e ondulada.

Horizonte C: + $345 \mathrm{~cm}$; vermelho (2,5YR 5/6), muito-argilosa, estrutura blocos subangulares, consistência seca dura e firme quando úmida; plástica e ligeiramente pegajosa; grande quantidade de plagioclásios intemperizados.

3.5: nesta camada, observa-se que as cores são pouco mais avermelhadas que a da fácies anterior e a estrutura é bem mais friável, os plagioclásios já se encontram bem mais alterados.

3.4: camada de alteração onde o material é bem mais friável. Os fenocristais de plagioclásio já apresentam sinais marcantes de alteração, com coloração modificada.

\section{PERFIL 4}


Horizonte BA: $0-73 \mathrm{~cm}$; vermelho escuro (2,5YR 3/6), muito-argilosa, estrutura maciça com alguns agregados subangulares de grau pouco desenvolvidos; cerosidade em algumas faces de agregados subangulares; consistência seca ligeiramente dura e friável quando úmida; plástica e pegajosa; pedotúbulos preenchidos por material microagregado e poucas raízes finas, transição difusa e plana.

Horizonte B1: 73 - $214 \mathrm{~cm}$; vermelho escuro (2,5YR 3/6), muito-argilosa, estrutura composta maciça a microgranular, consistência seca ligeiramente dura e friável quando úmida; plástica e pegajosa; raras raízes; transição difusa e plana.

Horizonte B2 : 214 - $446 \mathrm{~cm}$; vermelho (2,5YR 4/6), muito-argilosa, estrutura predominantemente microgranular com algumas porções de aspecto maciço; consistência seca ligeiramente dura e friável quando úmida; plástica e pegajosa; nódulos argilosos e ferruginosos, mais abundantes em direção a base; transição clara a gradual e plana a ondulada.

4.6 e 4.7: com uma coloração mais avermelhada que a anterior. Nota-se apenas uma diferença marcante entre essa duas alterações, na fácies 4.6 ocorre uma maior quantidade de pedotúbulos preenchidos totalmente por microagregados

4.5: as estruturas litológicas são reconhecíveis junto ao sistema de fraturamento original da rocha. As cores variam do acinzentado a uma coloração mais rosada. Os plagioclásios apresentam-se coloridos da mesma cor da matriz da rocha.

\section{PERFIL 5}

Horizonte A: $0-52 \mathrm{~cm}$; marrom avermelhado escuro (2,5YR 3/4), muito-argilosa, estrutura grumosa, pequena 0,3 a $0,7 \mathrm{~cm}$ e microgranular. consistência seca ligeiramente dura e friável quando úmida; plástica e pegajosa; raízes finas muito abundantes, transição difusa e plana.

Horizonte BA: 52 - $91 \mathrm{~cm}$; marrom avermelhado escuro (2,5YR 3/4), muito-argilosa, estrutura microgranular, consistência seca ligeiramente dura e friável quando úmida; plástica e pegajosa; ligeiramente mais coeso que o horizonte subjacente; transição difusa e plana. 
Horizonte B1: 91 - $237 \mathrm{~cm}$; marrom avermelhado (2,5YR 4/4), muito-argilosa, estrutura microagregada; consistência seca ligeiramente dura e friável quando úmida; plástica e pegajosa; alguns nódulos argilosos de tamanhos centimétricos em direção a base do horizonte; transição difusa e plana.

Horizonte B2: 237 - $444 \mathrm{~cm}$; marrom avermelhado (2,5YR 4/4), muito-argilosa, estrutura microagregada; consistência seca ligeiramente dura e friável quando úmida; plástica e pegajosa; nódulos ferruginosos centimétricos em direção a base do horizonte; transição difusa e plana.

Horizonte C: 460 - $527 \mathrm{~cm}$; marrom avermelhado (2,5YR 4/4), muito-argilosa, estrutura maciça à microagregados; consistência seca extremamente dura e extremamente firme quando úmida; não plástica e não pegajosa, grande quantidade de plagioclásios intemperizados.

5.4: fácies de rocha muito alterada as cores são mais acinzentadas. A estrutura foi toda destruída tornando-se uma rocha muito friável.

5.3: fácies de rocha alterada predominam cores amareladas e o material é bem mais friável. Os fenocristais de plagioclásio apresentam sinais marcantes de alteração, com coloração modificada.

5.2: fácies de rocha pouco alterada sendo caracterizada pelo início de alteração da rocha. Apresenta leves modificações da cor original da rocha sã, exibindo tons amarelados à cinza amarelados. 